\title{
Cochrane
}

Library

Cochrane Database of Systematic Reviews

\section{Effect of timing of umbilical cord clamping of term infants on maternal and neonatal outcomes (Review)}

McDonald SJ, Middleton P, Dowswell T, Morris PS

McDonald SJ, Middleton P, Dowswell T, Morris PS.

Effect of timing of umbilical cord clamping of term infants on maternal and neonatal outcomes.

Cochrane Database of Systematic Reviews 2013, Issue 7. Art. No.: CD004074.

DOI: 10.1002/14651858.CD004074.pub3.

www.cochranelibrary.com

Effect of timing of umbilical cord clamping of term infants on maternal and neonatal outcomes (Review) Copyright $\odot 2015$ The Cochrane Collaboration. Published by John Wiley \& Sons, Ltd. 
TABLE OF CONTENTS

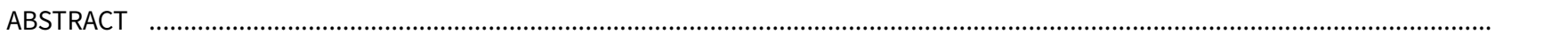

PLAIN LANGUAGE SUMMARY

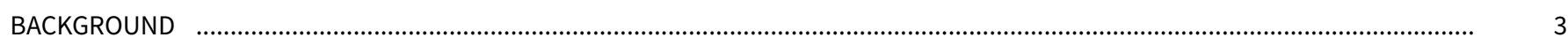

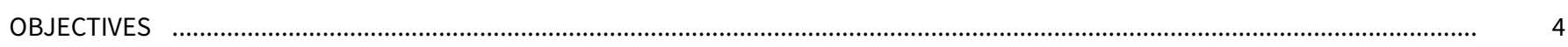

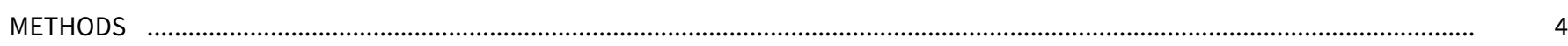

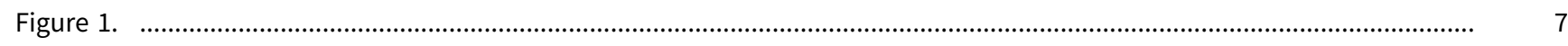

Figure 2.

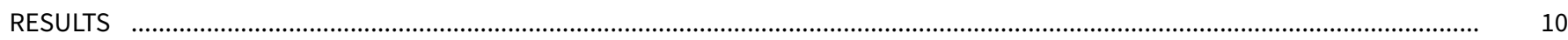

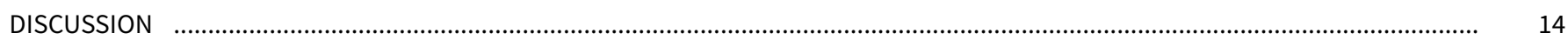

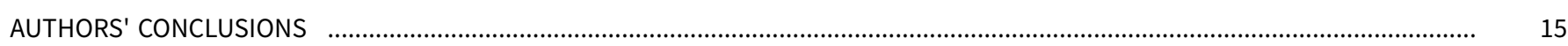

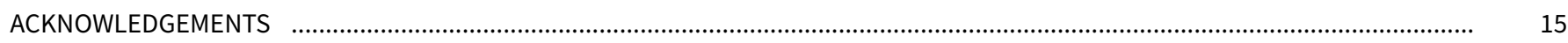

REFERENCES

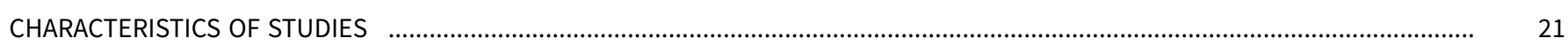

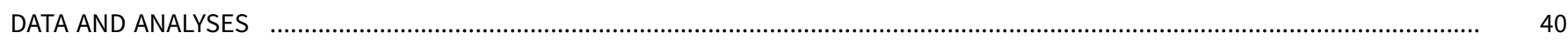

Analysis 1.1. Comparison 1 Early versus late cord clamping, Outcome 1 Severe PPH/blood loss $1000 \mathrm{~mL}$ or more. .................... 46

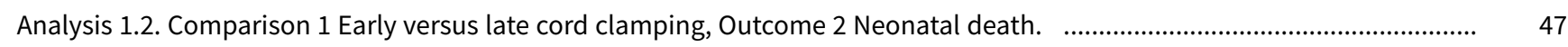

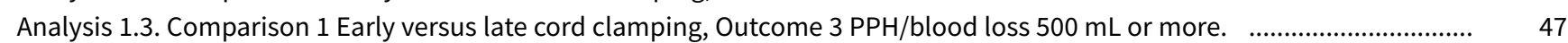

Analysis 1.4. Comparison 1 Early versus late cord clamping, Outcome 4 Mean blood loss $(\mathrm{mL})$. ............................................... 48

Analysis 1.5. Comparison 1 Early versus late cord clamping, Outcome 5 Maternal haemoglobin (g/dL) 24 to 72 hours 48

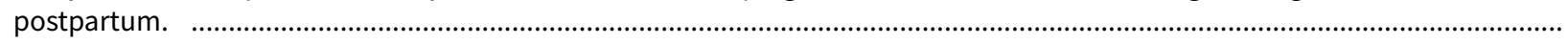

Analysis 1.6. Comparison 1 Early versus late cord clamping, Outcome 6 Need for blood transfusion.

Analysis 1.7. Comparison 1 Early versus late cord clamping, Outcome 7 Need for manual removal of placenta. ......................

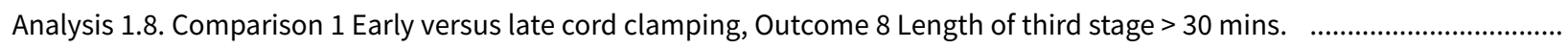

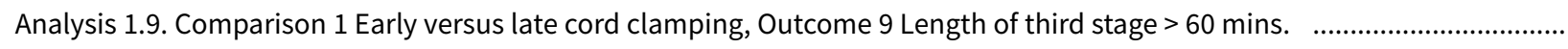

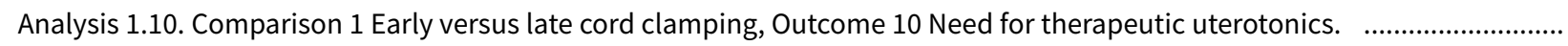

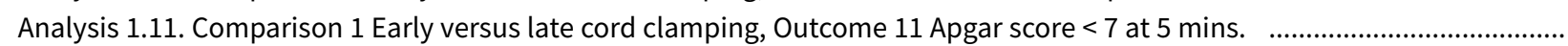

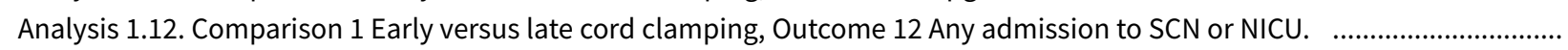

Analysis 1.13. Comparison 1 Early versus late cord clamping, Outcome 13 Respiratory distress.

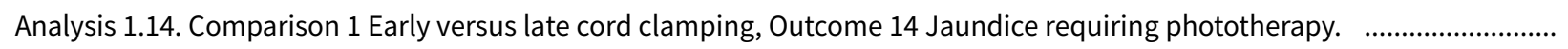

Analysis 1.15. Comparison 1 Early versus late cord clamping, Outcome 15 Clinical jaundice.

Analysis 1.16. Comparison 1 Early versus late cord clamping, Outcome 16 Polycythaemia. ...................................................

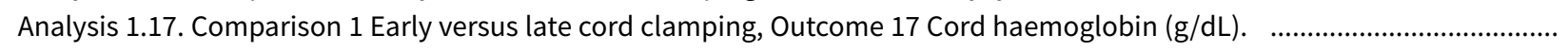

Analysis 1.18. Comparison 1 Early versus late cord clamping, Outcome 18 Newborn haemoglobin (g/dL). ............................

Analysis 1.19. Comparison 1 Early versus late cord clamping, Outcome 19 Infant haemoglobin at 24-48 hours (g/dL). ............

Analysis 1.20. Comparison 1 Early versus late cord clamping, Outcome 20 Infant haemoglobin at 3-6 months (g/dL). ............

Analysis 1.21. Comparison 1 Early versus late cord clamping, Outcome 21 Low infant haemoglobin at 3-6 months. ................

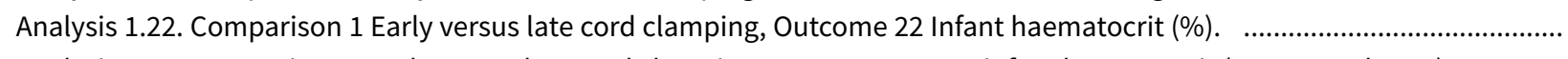

Analysis 1.23. Comparison 1 Early versus late cord clamping, Outcome 23 Low infant haematocrit ( $<45 \%$ at 6 hours). ............

Analysis 1.24. Comparison 1 Early versus late cord clamping, Outcome 24 Low infant haematocrit (<45\% at $24-48$ hours). .....

Analysis 1.25. Comparison 1 Early versus late cord clamping, Outcome 25 Infant iron deficiency at 3-6 months. ....................

Analysis 1.26. Comparison 1 Early versus late cord clamping, Outcome 26 Birthweight (g).

Analysis 1.27. Comparison 1 Early versus late cord clamping, Outcome 27 Not breastfeeding on discharge (or later). ..............

Analysis 1.28. Comparison 1 Early versus late cord clamping, Outcome 28 Neurodevelopment at 4 months. ...........................

Analysis 1.29. Comparison 1 Early versus late cord clamping, Outcome 29 Symptoms of infection during first 4 months. ........ ADDITIONAL TABLES

FEEDBACK

WHAT'S NEW

HISTORY

CONTRIBUTIONS OF AUTHORS

DECLARATIONS OF INTEREST

SOURCES OF SUPPORT 
[Intervention Review]

\title{
Effect of timing of umbilical cord clamping of term infants on maternal and neonatal outcomes
}

Susan J McDonald ${ }^{1}$, Philippa Middleton ${ }^{2}$, Therese Dowswell ${ }^{3}$, Peter S Morris ${ }^{4}$

1Midwifery Professorial Unit, La Trobe University/Mercy Hospital for Women, Melbourne, Australia. 2Women's and Children's Health Research Institute, The University of Adelaide, Adelaide, Australia. ${ }^{3}$ Cochrane Pregnancy and Childbirth Group, Department of Women's and Children's Health, The University of Liverpool, Liverpool, UK. ${ }^{4}$ Child Health Division, Menzies School of Health Research, Charles Darwin University, Darwin, Australia

Contact: Susan J McDonald, Midwifery Professorial Unit, La Trobe University/Mercy Hospital for Women, Level 4, Room 4.071, 163 Studley Road, Heidelberg, Melbourne, Victoria, 3084, Australia.s.mcdonald@latrobe.edu.au, sue.mcdonald@mercy.com.au.

Editorial group: Cochrane Pregnancy and Childbirth Group.

Publication status and date: Edited (no change to conclusions), comment added to review, published in Issue 12, 2015.

Citation: McDonald SJ, Middleton P, Dowswell T, Morris PS. Effect of timing of umbilical cord clamping of term infants on maternal and neonatal outcomes. Cochrane Database of Systematic Reviews 2013, Issue 7. Art. No.: CD004074. DOI: 10.1002/14651858.CD004074.pub3.

Copyright $(2015$ The Cochrane Collaboration. Published by John Wiley \& Sons, Ltd.

\begin{abstract}
A B S T R A C T

\section{Background}

Policies for timing of cord clamping vary, with early cord clamping generally carried out in the first 60 seconds after birth, whereas later cord clamping usually involves clamping the umbilical cord more than one minute after the birth or when cord pulsation has ceased. The benefits and potential harms of each policy are debated.
\end{abstract}

\section{Objectives}

To determine the effects of early cord clamping compared with late cord clamping after birth on maternal and neonatal outcomes

\section{Search methods}

We searched the Cochrane Pregnancy and Childbirth Group's Trials Register (13 February 2013).

\section{Selection criteria}

Randomised controlled trials comparing early and late cord clamping.

\section{Data collection and analysis}

Two review authors independently assessed trial eligibility and quality and extracted data.

\section{Main results}

We included 15 trials involving a total of 3911 women and infant pairs. We judged the trials to have an overall moderate risk of bias.

Maternal outcomes: No studies in this review reported on maternal death or on severe maternal morbidity. There were no significant differences between early versus late cord clamping groups for the primary outcome of severe postpartum haemorrhage (risk ratio (RR) $1.04,95 \%$ confidence interval $(\mathrm{Cl}) 0.65$ to 1.65 ; five trials with data for 2066 women with a late clamping event rate (LCER) of $3.5 \%, 120 \%)$ or for postpartum haemorrhage of $500 \mathrm{~mL}$ or more (RR $1.1795 \% \mathrm{Cl} 0.94$ to 1.44 ; five trials, 2260 women with a LCER of $\sim 12 \%, 120 \%$ ). There were no significant differences between subgroups depending on the use of uterotonic drugs. Mean blood loss was reported in only two trials with data for 1345 women, with no significant differences seen between groups; or for maternal haemoglobin values (mean difference (MD) $-0.12 \mathrm{~g} / \mathrm{dL} ; 95 \% \mathrm{Cl}-0.30$ to $0.06,120 \%$ at 24 to 72 hours after the birth in three trials. 
Neonatal outcomes: There were no significant differences between early and late clamping for the primary outcome of neonatal mortality (RR $0.37,95 \% \mathrm{Cl} 0.04$ to 3.41 , two trials, 381 infants with a LCER of ${ }^{1 \%} \%$ ), or for most other neonatal morbidity outcomes, such as Apgar score less than seven at five minutes or admission to the special care nursery or neonatal intensive care unit. Mean birthweight was significantly higher in the late, compared with early, cord clamping ( $101 \mathrm{~g}$ increase $95 \% \mathrm{Cl} 45$ to 157, random-effects model, 12 trials, 3139 infants, 12 $62 \%)$. Fewer infants in the early cord clamping group required phototherapy for jaundice than in the late cord clamping group (RR 0.62 , $95 \% \mathrm{Cl} 0.41$ to 0.96 , data from seven trials, 2324 infants with a LCER of $4.36 \%, 120 \%$ ). Haemoglobin concentration in infants at 24 to 48 hours was significantly lower in the early cord clamping group (MD $-1.49 \mathrm{~g} / \mathrm{dL}, 95 \% \mathrm{Cl}-1.78$ to $-1.21 ; 884$ infants, $\mathrm{I}^{2} 59 \%$ ). This difference in haemoglobin concentration was not seen at subsequent assessments. However, improvement in iron stores appeared to persist, with infants in the early cord clamping over twice as likely to be iron deficient at three to six months compared with infants whose cord clamping was delayed (RR $2.6595 \% \mathrm{Cl} 1.04$ to 6.73 , five trials, 1152 infants, 12 82\%). In the only trial to report longer-term neurodevelopmental outcomes so far, no overall differences between early and late clamping were seen for Ages and Stages Questionnaire scores.

\section{Authors' conclusions}

A more liberal approach to delaying clamping of the umbilical cord in healthy term infants appears to be warranted, particularly in light of growing evidence that delayed cord clamping increases early haemoglobin concentrations and iron stores in infants. Delayed cord clamping is likely to be beneficial as long as access to treatment for jaundice requiring phototherapy is available.

\section{PLAIN LANGUAGE SUMMARY}

\section{Effect of timing of umbilical cord clamping of term infants on mother and baby outcomes}

At the time of birth, the infant is still attached to the mother via the umbilical cord, which is part of the placenta. The infant is usually separated from the placenta by clamping the cord. This clamping is one part of the third stage of labour (the time from birth of the baby until delivery of the placenta) and the timing can vary according to clinical policy and practice. Although early cord clamping has been thought to reduce the risk of bleeding after birth (postpartum haemorrhage), this review of 15 randomised trials involving a total of 3911 women and infant pairs showed no significant difference in postpartum haemorrhage rates when early and late cord clamping (generally between one and three minutes) were compared. There were, however, some potentially important advantages of delayed cord clamping in healthy term infants, such as higher birthweight, early haemoglobin concentration, and increased iron reserves up to six months after birth. These need to be balanced against a small additional risk of jaundice in newborns that requires phototherapy. 


\section{B A C K G R O U N D}

\section{Description of the condition}

At the time of birth, the infant is still attached to the mother via the umbilical cord, which is part of the placenta. The infant is usually separated from the placenta by clamping the cord with two clamps. One clamp is placed close to the infant's navel and the second is placed further along the umbilical cord; then the cord is cut between the two clamps. This task takes place during the third stage of labour, which is the period of time from the birth of the infant to the delivery of the placenta.

\section{Description of the intervention}

\section{Active management and expectant management of the third stage of labour}

There are two contrasting approaches to managing the third stage of labour: active management and expectant or physiological management. A comparison of these approaches is the subject of a separate Cochrane review (Begley 2011).

Expectant management is a non-interventionist approach to care in the third stage of labour that involves waiting for signs of placental separation and allowing the placenta to deliver spontaneously or aided by gravity, maternal effort or nipple stimulation. In many high-resource settings, and in some low-resource settings, this approach has frequently been replaced by more interventionist packages of care (active management), although variation in practice remains widespread.

Active management of the third stage of labour has been described in a recent World Health Organization (WHO) report as the "cornerstone" of obstetric and midwifery practice during the latter part of the 20th century (WHO 2012b). Active management has involved the clinician intervening in the process through three interrelated processes: the administration of a prophylactic uterotonic drug; cord clamping and cutting; and controlled traction of the umbilical cord. An injection of an uterotonic drug, an agent that stimulates the uterus to contract, is given as a precautionary measure, aimed at reducing the risk of postpartum haemorrhage (PPH). The timing of when prophylactic uterotonic drugs are administered has varied over time and in practice from administration with crowning of the baby's head; to at the time of birth of the anterior of the baby; to shortly after complete birth of the baby. There are also several different types of uterotonic drugs that may be given and the relative advantages and disadvantages of these different drugs are the subject of separate reviews (see Cotter 2001 (oxytocin); Gülmezoglu 2007 (prostaglandins and misoprostol); McDonald 2007 (ergometrineoxytocin and oxytocin)). In earlier descriptions of an active management strategy the umbilical cord was usually clamped within 60 seconds following birth of the infant, although there can be substantial variation in the application of policies for active management often related to the setting within which the policy is being applied. The WHO 2012b recommendation is for clamping of the cord to be performed between one to three minutes after the birth unless the baby is asphyxiated and requires resuscitation.

A major reason for practising active management is its association with reduced risk of PPH, the major complication of the third stage of labour (Prendiville 2000). The usual definition of PPH is that given by the WHO: blood loss of equal to or more than $500 \mathrm{~mL}$ from the genital tract during the first 24 hours postpartum (WHO 1990; WHO 2000; WHO 2012b). Stricter definitions of $600 \mathrm{~mL}$ (Beischer 1986) and $1000 \mathrm{~mL}$ (Burchell 1980) have been suggested although the assessment of blood loss is often significantly underestimated and is based on clinical estimation (Kwast 1991; WHO 1998a). The $500 \mathrm{~mL}$ limit is intended to be a warning and blood loss up to $1000 \mathrm{~mL}$ in healthy women may be well tolerated in some birth settings where there is access to adequate resuscitation measures if required. In other settings, particularly in low-income countries, where the prevalence of severe anaemia is high, this amount of blood loss would be life threatening for many women (WHO 1996). Assessment of women with blood loss should always also take into account physical appearance and physiological observations such as pulse rate, blood pressure and conscious state. PPH is the most common fatal complication of pregnancy and childbirth in the world (UN 2010; UNICEF 2002; WHO 2007; WHO 2012) and is a major contributor to the conservatively estimated 287,000 maternal deaths occurring throughout the world annually (WHO 2012). Whilst the majority of maternal deaths (99\%) occur in low-income countries (WHO 2002), the risk of PPH should not be underestimated for any birth (McDonald 2003). Effects on maternal morbidity are less well documented, but are likely to include interrelated outcomes such as anaemia and fatigue (Patterson 1994). Complications that can arise from major blood loss include shock, the widespread formation of blood clots in the microcirculation, renal failure, liver failure and adult respiratory distress syndrome (Bonnar 2000).

Although active management leads to reduced risk of PPH, it is important to establish whether individual components of the strategy lead to this reduced risk or whether it requires the full 'package' of strategies to be administered. Furthermore, It can be difficult to adhere to an active management strategy. Over time the type of uterotonic drug and the timing of its administration has been reported as being with crowning of the head of the baby, birth of the anterior shoulder of the infant after the birth of the baby or after the clamping of the cord. Variations in practice may be related to practical considerations such the number of staff available in the room at the time of birth, unexpected occurrences such as malpresentation (for example, a breech presentation) or shoulder dystocia (difficulty in delivering the infant's shoulders), local policy, or birth setting context. Some women also have preferences for expectant management (McDonald 2003). Thus, it is important to examine the relative importance of each component of an active management strategy.

\section{Early cord clamping as part of active management}

In the past, as part of an active management strategy, the umbilical cord has usually been clamped shortly following birth of the infant. This was generally advised to be carried out in the first 30 seconds after birth, regardless of whether the cord pulsation has ceased (McDonald 2003). As part of this strategy the infant may have been placed on the mother's abdomen, put to the breast or have been more closely examined on a warmed cot if resuscitation was required. Once the placenta was felt to have separated from the wall of the uterus, downward traction may have been applied to the remaining length of the umbilical cord to assist delivery of the placenta. Controlled cord traction is believed to reduce blood loss, shorten the third stage of labour and therefore minimise the time during which the mother is at risk from haemorrhage (McDonald 2003). However, more recent guidelines 
for management of the third stage of labour no longer recommend immediate cord clamping, and cord traction is regarded as optional and is only suggested when skilled staff are in attendance (WHO 2012b).

\section{Delayed cord clamping}

Definitions of what constitutes early and late cord clamping vary (Prendiville 1989). In practice, clamping the umbilical cord often takes place once cord pulsation has ceased or at least beyond the first minute of so following the birth of the baby.

\section{How the intervention might work}

\section{Possible beneficial and adverse effects}

Delayed clamping allows time for a transfer of the fetal blood in the placenta to the infant at the time of birth. This placental transfusion can provide the infant with an additional $30 \%$ more blood volume and up to $60 \%$ more red blood cells (McDonald 2003; Mercer 2001; Mercer 2006; Palethorpe 2010). The amount of blood returned to the infant depends on when the cord is clamped and at what level the infant is held (above or below the mother's abdomen) prior to clamping (Yao 1974). Palethorpe 2010 and colleagues sought to evaluate studies related to the effects for mother and baby of alternative positions for the baby between birth and cord clamping to assess the influence of gravity on placental transfusion. However, no randomised controlled trials were identified for comparison and they concluded there was a need for large, well designed randomised controlled trials to be undertaken to ascertain what effect gravity may have on placental transfusion at vaginal and caesarean births related to short- and longer-term outcomes for mothers and babies.

The suggested neonatal benefits associated with this increased placental transfusion include higher haemoglobin concentrations (Prendiville 1989), additional iron stores and less anaemia later in infancy (Chaparro 2006; WHO 1998b), higher red blood cell flow to vital organs, better cardiopulmonary adaptation, and increased duration of early breastfeeding (Mercer 2001; Mercer 2006). There is growing evidence that delaying cord clamping confers improved iron status in infants up to six months post birth (Chaparro 2006; Mercer 2006; van Rheenen 2004).

Arguments against early cord clamping include the reduction in the amount of placental transfusion and any associated benefits of extra blood volume. Early cord clamping may increase the likelihood of feto-maternal transfusion (the amount of blood that is forced back across the placental barrier into the maternal circulation), as a larger volume of blood remains in the placenta. This would have been considered a potential issue prior to the introduction of $\mathrm{Rh} \mathrm{D}$ immunoglobulin prophylaxis, since early clamping of the cord was considered to increase the risk. However, little work appears to have been undertaken since findings from small non-randomised studies (Lapido 1972) suggested there may be a reduction in feto-maternal transfusion if cord clamping was delayed (Smith 2006). Early clamping has also been thought to be associated with higher risks for the preterm infant. This topic is the subject of a Cochrane systematic review (Rabe 2012), which has recently been updated.

Delayed cord clamping has been linked to an increase in the incidence of jaundice (Prendiville 1989) which, in severe cases, could have longer term effects on the health and development of the infant. In addition, early cord clamping has been associated with a reduction in the length of the third stage of labour. One of the aims of active management is to reduce the length of the third stage because the longer the placenta remains undelivered, the greater is the likelihood of maternal bleeding (Inch 1985). A delay in time before clamping the umbilical cord in healthy term infants appears be less crucial as the cord ceases pulsation within the first two minutes of birth in the majority of cases (McDonald 2003).

\section{Why it is important to do this review}

\section{Why this review is important}

Active management, including early cord clamping is still widely practised in high-income countries, although relative timing of each individual component of the strategy varies. Most maternity units in Australia and the United Kingdom administer the uterotonic prior to placental delivery, whereas some units in the United States (Brucker 2001) and Canada (Baskett 1992) advocate withholding uterotonic administration until after the placenta is delivered. A survey of active management policies in Europe showed considerable differences, including the timing of cord clamping, with eight countries clamping the cord immediately in $66 \%$ to $90 \%$ of units, and five countries mostly waiting until the cord stopped pulsating (Winter 2007).

WHO recently updated its guidelines on preventing PPH (WHO 2012b). The International Confederation of Midwives and the International Federation of Gynaecology and Obstetrics also updated its statement on PPH in 2006 (ICM/FIGO 2006). Both statements refer to benefits of delaying cord clamping, and WHO recommend cord clamping one to three minutes after the birth although the quality of the evidence underpinning this recommendation was described as moderate. This review seeks to explore this issue further. Since evidence suggests that the effects of early versus late cord clamping may differ in preterm and term infants, these are the subjects of a separate review (see Rabe 2012). This review will concentrate on the effect of early versus late cord clamping on maternal and neonatal outcomes in term infants.

\section{O B JECT IVES}

The objective of this review was to determine the maternal and neonatal effects of different policies for the timing of cord clamping in the third stage of labour.

\section{METHODS}

\section{Criteria for considering studies for this review}

\section{Types of studies}

We considered all randomised comparisons of different strategies for the timing of umbilical cord clamping of term infants during the third stage of labour for inclusion. We excluded quasi-randomised studies.

\section{Types of participants}

Women who:

1. have given birth to a term infant (equal to or greater than 37 completed weeks' gestation); and

2. have been involved in a birth where clamping of the umbilical cord is applied (including caesarean section). 


\section{Exclusions}

1. Women who have given birth to a pre-term infant (less than 37 weeks' gestation; as these are the subject of separate reviews, see Rabe 2012.

2. Breech presentation.

3. Multiple pregnancies.

Exclusions 2 and 3 were due to the lack of control over the timing of cord clamping in these conditions.

\section{Types of interventions}

1. Early cord clamping, defined as application of a clamp to the umbilical cord within 60 seconds of the birth of the infant

2. Later (delayed) cord clamping, defined as application of a clamp to the umbilical cord greater than one minute after birth or when cord pulsation has ceased

\section{Types of outcome measures}

The outcome measures chosen in this review were based on those factors that were likely to be seen as clinically relevant in terms of an outcome changing clinical practice.

\section{Primary outcomes}

1. Severe PPH (measured blood loss $1000 \mathrm{~mL}$ or more, or, as defined by the trial authors)

2. Maternal death or severe morbidity composite (major surgery, organ failure, intensive care unit (ICU) admission, or as defined by trial authors)

3. Neonatal mortality

\section{Secondary outcomes}

\section{Maternal}

1. Maternal death

2. Individual components of severe morbidity (as listed above or as defined by the trial authors)

3. PPH (clinically estimated blood loss of at least $500 \mathrm{~mL}$, or as defined by the trial authors)

4. Length of third stage of labour

5. Mean blood loss

6. Manual removal of the placenta

7. Blood transfusion

8. Use of therapeutic uterotonics

9. Additional treatment for PPH (uterine tamponade, $x$-ray, embolisation)

10.Adverse effects reported either individually or as a composite where appropriate; e.g. vomiting, nausea, elevation of diastolic blood pressure, shivering, headache, chest pain, shortness of breath, pyrexia, diarrhoea

11.Postnatal anaemia (defined by trial authors, absolute or relative drop in haemoglobin)

12. Thrombo-embolic events

13. Cost

\section{Neonatal}

1. Birthweight
2. Apgar score less than seven at five minutes

3. Admission to neonatal intensive care unit or special care nursery

4. Respiratory distress

5. Hypoxia

6. Jaundice requiring phototherapy

7. Clinical jaundice

8. Cord haemoglobin concentrations

9. Not breastfed at discharge

10.Neonatal and infant anaemia up to four to six months post birth

11.Neonatal and infant haemoglobin concentrations

12. Neonatal and infant haematocrit

13. Neonatal and child neurodevelopmental outcome

14.Polycythaemia (haematocrit greater than 65\%)

15. Neonatal and infant ferritin concentrations

16.Symptoms of infection in infants

\section{Search methods for identification of studies}

\section{Electronic searches}

We searched the Cochrane Pregnancy and Childbirth Group's Trials Register by contacting the Trials Search Co-ordinator (13 February 2013).

The Cochrane Pregnancy and Childbirth Group's Trials Register is maintained by the Trials Search Co-ordinator and contains trials identified from:

1. monthly searches of the Cochrane Central Register of Controlled Trials (CENTRAL);

2. weekly searches of MEDLINE;

3. weekly searches of EMBASE;

4. handsearches of 30 journals and the proceedings of major conferences;

5. weekly current awareness alerts for a further 44 journals plus monthly BioMed Central email alerts.

Details of the search strategies for CENTRAL, MEDLINE and EMBASE, the list of handsearched journals and conference proceedings, and the list of journals reviewed via the current awareness service can be found in the 'Specialized Register' section within the editorial information about the Cochrane Pregnancy and Childbirth Group.

Trials identified through the searching activities described above are each assigned to a review topic (or topics). The Trials Search Coordinator searches the register for each review using the topic list rather than keywords.

We did not apply any language restrictions.

\section{Data collection and analysis}

\section{Selection of studies}

At least two review authors independently assessed the full text of potential studies for the appropriateness of inclusion.

\section{Data extraction and management}

We performed data extraction separately and double checked data for discrepancies. Careful assessment and data extraction of the McDonald 1996 trial was made independently by three people not 
involved with this trial (J Abbott, S Higgins and P Middleton). We undertook thorough discussions between review authors about the appropriateness of all other studies for inclusion. We contacted individual investigators if we required clarification before deciding if a trial met the inclusion criteria.

\section{Assessment of risk of bias of included studies}

We assessed the risk of bias in each study using the criteria outlined in the Cochrane Handbook for Systematic Reviews of Interventions (Higgins 2011).

Any disagreement was resolved by discussion or by involving a third assessor.

\section{(1) Sequence generation (checking for possible selection bias)}

We have described for each included study the method used to generate the allocation sequence and assessed whether it was likely to produce comparable groups.

We assessed the method as:

- low risk of bias (any truly random process, e.g. random number table; computer random number generator);

- high risk of bias (any non random process, e.g. odd or even date of birth; hospital or clinic record number);

- unclear risk of bias.

\section{(2) Allocation concealment (checking for possible selection bias)}

We have described for each included study the method used to conceal the allocation sequence and assessed whether the treatment allocation could have been foreseen in advance of, or during recruitment, or changed after assignment.

We assessed the methods as:

- low risk of bias (e.g. telephone or central randomisation; consecutively numbered sealed opaque envelopes);

- high risk of bias (open random allocation; unsealed or nonopaque envelopes, alternation; date of birth);

- unclear risk of bias.

\section{(3) Blinding (checking for possible performance or detection} bias)

For this type of intervention blinding women and clinical staff is generally not feasible, although it may be possible to blind outcome assessors. We have assessed blinding for outcome assessors as:

- low, high or unclear risk of bias.
(4) Incomplete outcome data (checking for possible attrition bias through withdrawals, dropouts, protocol deviations)

We have described for each included study the completeness of data including attrition and exclusions from the analysis. We have reported the numbers included in the analysis at each stage (compared with the total randomised participants), reasons for attrition or exclusion where reported, and whether missing data were balanced across groups or were related to outcomes. We assessed methods as:

- low, high or unclear risk of bias.

\section{(5) Selective reporting bias}

We have described for each included study whether we suspected any selective outcome reporting bias.

We assessed the methods as:

- low risk of bias (where it is clear that all of the study's prespecified outcomes and all expected outcomes of interest to the review have been reported);

- high risk of bias (where not all the study's pre-specified outcomes have been reported; one or more reported primary outcomes were not pre-specified; outcomes of interest are reported incompletely and so cannot be used; study failed to include results of a key outcome that would have been expected to have been reported);

- unclear risk of bias.

\section{(6) Other sources of bias}

We have described for each included study any important concerns we had about other possible sources of bias.

We assessed whether each study was free of other problems that could put it at risk of bias:

- (low risk of other bias);

- (high risk of other bias);

- unclear risk of other bias.

\section{(7) Overall risk of bias}

We have made explicit judgements about whether studies are at high risk of bias, according to the criteria given in the Cochrane Handbook for Systematic Reviews of Interventions (Higgins 2011). With reference to (1) to (6) above, we assessed the likely magnitude and direction of the bias, and whether we considered it was likely to impact on the findings. We explored the impact of possible bias through undertaking sensitivity analyses - see Sensitivity analysis.

Overall findings for our assessment of risk of bias in the included studies are set out in Figure 1 and Figure 2. 
Figure 1. 'Risk of bias' graph: review authors' judgements about each risk of bias item presented as percentages across all included studies.

$$
\text { Random sequence generation (selection bias) }
$$

Allocation concealment (selection bias)

Blinding (performance bias and detection bias)

Incomplete outcome data (attrition bias)

Selective reporting (reporting bias)

Other bias
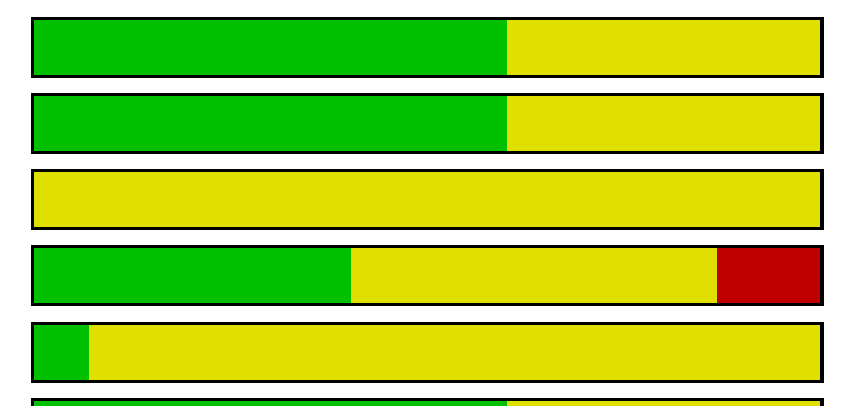

Other bias

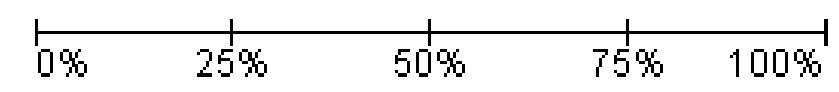


Figure 2. 'Risk of bias' summary: review authors' judgements about each risk of bias item for each included study.

\begin{tabular}{|c|c|c|c|c|c|c|}
\hline & 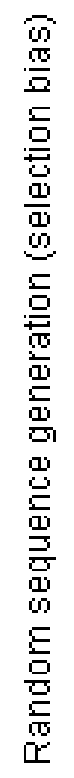 & 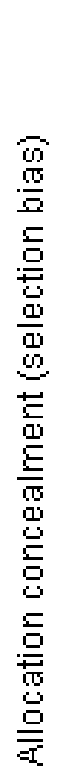 & 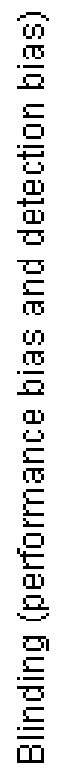 & 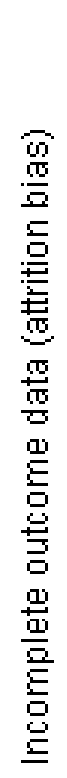 & 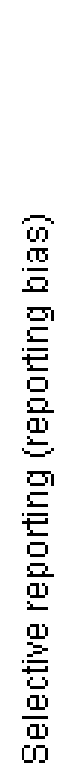 & 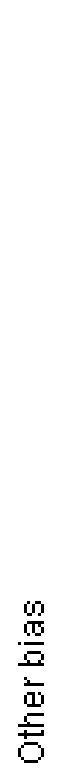 \\
\hline Al-Tawil 2012 & $?$ & $?$ & $?$ & - & $?$ & + \\
\hline Andersson 2011 & + & + & $?$ & $?$ & $?$ & $?$ \\
\hline Cernadas 2006 & + & $\odot$ & $?$ & + & ? & $?$ \\
\hline Chaparro 2006 & + & + & $?$ & $?$ & $?$ & + \\
\hline Emhamed 2004 & $?$ & + & ? & + & $?$ & + \\
\hline Geethanath 1997 & + & + & ? & + & $?$ & + \\
\hline Gupta 2002 & + & + & ? & & $?$ & + \\
\hline Jahazi 2008 & + & $?$ & ? & ? & ? & $?$ \\
\hline McDonald 1996 & + & + & $?$ & + & + & + \\
\hline Nelson 1980 & ? & ? & ? & + & ? & + \\
\hline Oxford Midwives 1991 & + & + & $?$ & + & $?$ & ? \\
\hline Philip 1973 & ? & $?$ & ? & ? & ? & + \\
\hline Saigal 1972 & ? & ? & ? & ? & ? & ? \\
\hline Spears 1966 & ? & ? & ? & ? & ? & ? \\
\hline van Rheenen 2007 & + & + & $?$ & ? & ? & + \\
\hline
\end{tabular}

Effect of timing of umbilical cord clamping of term infants on maternal and neonatal outcomes (Review) Copyright $\odot 2015$ The Cochrane Collaboration. Published by John Wiley \& Sons, Ltd. 


\section{Measures of treatment effect}

\section{Dichotomous data}

For dichotomous data, we have presented results as summary risk ratio with $95 \%$ confidence intervals $(\mathrm{Cl})$.

\section{Continuous data}

For continuous data, we used the mean difference as outcomes were measured in the same way between trials. We planned to use the standardised mean difference to combine trials that measured the same outcome, but used different methods.

\section{Unit of analysis issues}

\section{Cluster-randomised trials}

We planned to include cluster-randomised trials along with individually-randomised trials. In this updated version of the review no cluster-randomised trials were identified in the search. In future versions, if any such trials are identified and assessed as eligible for inclusion, we will adjust their sample sizes using the methods described in the Cochrane Handbook for Systematic Reviews of Interventions (Higgins 2011) using an estimate of the intracluster correlation co-efficient (ICC) derived from the trial (if possible), or from another source. If ICCs from other sources are used, we will note this and carried out sensitivity analyses to investigate the effect of variation in ICC. We will synthesise the findings from individually- and cluster-randomised trials provided that there is little heterogeneity between the study designs and the interaction between the effect of intervention and the choice of randomisation unit is considered to be unlikely.

\section{Dealing with missing data}

For included studies, we noted levels of attrition in the Characteristics of included studies tables.

We analysed data on all participants with available data in the group to which they were allocated, regardless of whether or not they received the allocated intervention. If in the original reports participants were not analysed in the group to which they were randomised, and there was sufficient information in the trial report, we attempted to restore them to the correct group.

For all outcomes, we carried out analyses, as far as possible, on an intention-to-treat basis, i.e. we attempted to include all participants randomised to each group in the analyses. For all primary outcomes the denominator for each outcome in each trial is the number of women randomised.

\section{Assessment of heterogeneity}

We used the $\mathrm{I}^{2}$ and $\mathrm{T}^{2}$ statistics to quantify heterogeneity along with the $\mathrm{Chi}^{2}$ test for heterogeneity. If we identified substantial heterogeneity $\left(I^{2}\right.$ greater than $\left.30 \%\right)$, we have drawn attention to this in the text and have advised readers to interpret results with caution. For primary outcomes where moderate or high levels of heterogeneity were identified we also planned to calculate the $95 \%$ prediction interval which gives the range of effects expected across different settings; in this version of the review we did not identify high levels of heterogeneity for primary outcomes.

\section{Assessment of reporting biases}

For primary outcomes, provided sufficient studies contributed data, we planned to generate funnel plots. In this version of the review insufficient studies contributed data for any of our primary outcomes. In future updates, if further data are added, we will visually examine plots to see whether there is any evidence of asymmetry suggesting different treatment effects in smaller studies, which may indicate publication bias (Harbord 2006).

\section{Data synthesis}

We carried out statistical analysis using the Review Manager software (RevMan 2011). We used fixed-effect analysis for combining data in the absence of significant heterogeneity and when trials were sufficiently similar. If heterogeneity was found, this was explored by sensitivity analysis followed by random-effects analysis if required. Random-effects meta-analysis estimates the average treatment effect and this may not always be clinically meaningful. Further, where there is high heterogeneity the applicability of the overall effect estimate is likely to vary in different settings and we therefore advise caution in the interpretation of results.

\section{Subgroup analysis and investigation of heterogeneity}

We planned to carry out the following subgroup analyses:

1. whether or not uterotonics (oxytocic drugs used to stimulate the uterus to contract) were used as part of the third stage management;

2. whether or not the infant was held above or below the abdomen prior to cord clamping;

3. the extent of control for selection bias.

The uterotonic subgroup was presented as part of the analysis structure.

There was insufficient information or variation to present subgroup analyses by placement of infant (however, this was noted in the Characteristics of included studies tables), or selection bias.

We only used primary outcomes in subgroup analysis.

We visually examined the forest plots of subgroup analyses to look at whether there was overlap between $95 \% \mathrm{Cls}$ for the effects in different groups; with non-overlapping $\mathrm{Cls}$ suggesting a difference between subgroups. We also conducted formal statistical analyses to examine any possible differences between subgroups classifying whole trials by interaction tests as described in the Cochrane Handbook for Systematic Reviews of Interventions (Higgins 2011) and available in RevMan 2011, We reported the results of interaction tests in the text.

\section{Sensitivity analysis}

We planned sensitivity analysis for primary outcomes by risk of bias; we did this by dividing the studies into subgroups according to whether they were at low risk of bias as opposed to unclear or high risk of bias for allocation concealment to see what impact this would have on the treatment effect. In this version of the review, all studies reporting on our primary outcomes were at low risk of bias for allocation concealment. 


\section{RES U L T S}

\section{Description of studies}

\section{Results of the search}

The search strategy identified 74 reports representing 58 studies (some studies resulted in several publications or reports). We included 15 studies and excluded 37 . In addition, four studies are awaiting assessment (Jaleel 2009; Li 2012; Nardozza 2012; Ping 2010); we have contacted three of the study authors for more information so that we can assess eligibility for inclusion. Two studies are still ongoing and we hope to include these in future updates of the review (Beal 2006; Hanson 2012). (See Characteristics of studies awaiting classification and Characteristics of ongoing studies for more information about these trials). The most recent search was carried out in February 2013.

\section{Included studies}

Fifteen studies with 3911 women contribute data to the review; all of the studies examined the effects of different timing of umbilical cord clamping in term infants. However, there were some differences between trials in the participants, settings, and the interventions (timing of cord clamping in the experimental and control groups and co-interventions). There were also differences in the outcomes measured, and in the way outcomes were measured in different studies; not all studies reported results for our primary outcomes, and for some outcomes relatively few studies contributed data. Therefore, when describing the effects of interventions we have indicated the number of studies and participants included in each analysis

\section{Participants}

Participants generally were healthy pregnant women expected to give birth vaginally. However, in Gupta 2002, the women were anaemic and the van Rheenen 2007 trial was conducted in a malaria-endemic area. Three studies (Andersson 2011; Cernadas 2006; Nelson 1980) included data for caesarean section birth. While in the Andersson 2011 and Nelson 1980 trials most women had vaginal births, in the trial by Cernadas 2006 over a quarter of the women randomised (79/276) had caesarean births.

\section{Settings}

Studies were conducted in Argentina (Cernadas 2006), Australia (McDonald 1996), Canada (Nelson 1980; Saigal 1972), India (Geethanath 1997; Gupta 2002), Iran (Jahazi 2008), Libya (Emhamed 2004), Mexico (Chaparro 2006), Saudi Arabia (Al-Tawil 2012), Sweden (Andersson 2011), UK (Oxford Midwives 1991; Philip 1973), USA (Spears 1966) and Zambia (van Rheenen 2007).

\section{Interventions}

\section{Timing of cord clamping}

While the timing of early clamping was relatively consistent between studies at less than one minute (mostly within 15 seconds of birth), the timing of late clamping was quite variable:

- one minute in one arm of Cernadas 2006 and Saigal 1972, with the latter holding the baby $30 \mathrm{~cm}$ below the perineum;
- more than 10 seconds after the doctor or midwife thought that the baby was breathing well (mean time 94 seconds after birth) (Philip 1973);

- two minutes in Chaparro 2006;

- three minutes in Al-Tawil 2012, Andersson 2011; Cernadas 2006; Jahazi 2008; Oxford Midwives 1991; and Spears 1966;

- when the cord stopped pulsing in Emhamed 2004; Nelson 1980 and van Rheenen 2007;

- when the cord stopped pulsing, or five minutes, in McDonald 1996;

- after placental descent in Geethanath 1997 (baby placed $10 \mathrm{cms}$ below the vaginal introitus) and Gupta 2002 (baby placed below the level of the mother's abdomen).

The one-minute and three-minute arms of Cernadas 2006 were combined to give data for late cord clamping; as were the oneminute and five-minute arms in Saigal 1972.

\section{Use and timing of uterotonic}

McDonald 1996 used a factorial design with four arms, randomising not only by early and late cord clamping but also by whether uterotonics were administered early or late. Early uterotonic administration involved administration at the time of birth of the anterior shoulder of the baby. Late uterotonic administration was after the birth of the baby (literally) and if the cord clamping allocation was early, then it was allocated to be after the cord was clamped (i.e. not within 30 seconds). The uterotonic used was intramuscular oxytocin $10 \mathrm{IU}$.

van Rheenen 2007 also used intramuscular oxytocin, but this was administered after clamping of the cord and no dosage was recorded.

In the Oxford Midwives 1991 trial, uterotonic was given at the time of birth of the anterior shoulder of baby in both arms; in Emhamed 2004 it was given when the cord was clamped; and in Philip 1973 and Saigal 1972 it was given after the cord was clamped.

The remaining nine trials did not specify either use or timing of any uterotonic (Al-Tawil 2012, Andersson 2011; Cernadas 2006; Chaparro 2006; Geethanath 1997; Gupta 2002; Jahazi 2008; Nelson 1980; Spears 1966).

See tables of Characteristics of included studies for further details of the included trials.

\section{Excluded studies}

We excluded 37 studies. The main reason for excluding studies was that they were not randomised controlled trials or it was not clear that they were randomised trials. Twenty-eight studies were excluded for this reason; some of these studies used quasirandomisation methods (for example alternate allocation) while in other cases the way participants were allocated to groups was not described. Five studies (Begley 1990; Khan 1997; Prendiville 1988; Rogers 1998; Thilaganathan 1993) examined active management of the third stage of labour which involves other interventions in addition to early cord clamping. Active management of the third stage of labour has been examined in a related Cochrane Review (Begley 2011). Four studies were excluded for other reasons - see Characteristics of excluded studies tables for more information. 


\section{Risk of bias in included studies}

\section{Allocation}

Seven trials used methods to generate the randomisation sequence that we assessed as low risk of bias such as computer randomisation or the use of random number tales (Andersson 2011; Cernadas 2006; Chaparro 2006; Geethanath 1997; Gupta 2002; McDonald 1996; Oxford Midwives 1991) and van Rheenen 2007 stated that the sequence was unpredictable (although the method of generation was not specified). Jahazi 2008 used a coin toss to generate the sequence, and in the remaining trials the method was either not stated or was not clear (Al-Tawil 2012; Emhamed 2004; Nelson 1980; Philip 1973; Saigal 1972; Spears 1966).

Nine studies used sequentially numbered sealed opaque envelopes to conceal allocation to randomisation groups (Andersson 2011; Cernadas 2006; Chaparro 2006; Emhamed 2004; Geethanath 1997; Gupta 2002; McDonald 1996; Oxford Midwives 1991; van Rheenen 2007). The remaining trials had unclear allocation concealment methods (Al-Tawil 2012, Jahazi 2008; Nelson 1980; Philip 1973; Saigal 1972; Spears 1966).

\section{Blinding}

Blinding women and the staff providing care is not possible when assessing the management of third stage of labour and the impact of lack of blinding on outcomes is difficult to assess. It may be feasible to blind staff collecting data for some outcomes. However, the assessment of many outcomes, particularly blood loss, could, in theory, have been unconsciously affected by people's beliefs. Having chosen maternal haemoglobin less than $9 \mathrm{~g} / \mathrm{dL}$ as a hard outcome relating to blood loss at the protocol stage, we have now also included the mean postnatal haemoglobin values to help in understanding the blood loss estimations. Haemoglobin assessment would usually be performed by a technician who would be blind to the trial allocation. Seven of the studies reported that an attempt was made to blind the collection of at least some of the outcome data to reduce detection bias (Al-Tawil 2012, Andersson 2011; Cernadas 2006; McDonald 1996; Oxford Midwives 1991; Nelson 1980; van Rheenen 2007). In the 'Risk of bias' tables, we have provided a single assessment of risk of bias associated with blinding but have noted where authors report blinding outcome assessment for some or all outcomes.

\section{Incomplete outcome data}

Even low loss to follow-up may cause serious risk of bias for rare outcomes. Attrition was relatively low in the studies by Cernadas 2006; McDonald 1996; and Nelson 1980, and more than $80 \%$ of the randomised samples were available at follow-up in the studies by Andersson 2011; Emhamed 2004; and Geethanath 1997. In the Oxford Midwives 1991 study, there were protocol deviations but there was an intention-to-treat (ITT) analysis for all women according to randomisation group. In Chaparro 2006, $29 \%$ of participants were lost to follow-up at six months and van Rheenen 2007 had lost about 33\% of participants (including post-randomisation exclusions) by six months, and there was very high attrition in the study by Gupta 2002. In four trials, loss to follow-up was either not stated or unclear (Jahazi 2008; Philip 1973; Saigal 1972; Spears 1966). In the trial by Al-Tawil 2012, although sample attrition was modest (11\%), there appeared to have been exclusions after randomisation, which were not reported by randomisation group, and there was no ITT analysis. Most of our outcomes relate to the period just after the birth when sample attrition in most studies was likely to have been low.

\section{Selective reporting}

Most of the studies were assessed as unclear for selective reporting bias as we did not have access to study protocols and under these circumstances it was difficult to know whether investigators had omitted important findings.

\section{Other potential sources of bias}

We identified few other obvious sources of bias; study groups appeared comparable at baseline. In three studies there was very little information about study methods and therefore, we assessed these studies as unclear for other bias (Jahazi 2008; Saigal 1972; Spears 1966). It is possible that if staff carrying out interventions were deviating from 'routine' this may have introduced bias; for example, in Andersson 2011 early clamping was routine before the trial, and staff may have had views about late clamping which may have affected the way the intervention was delivered for the late clamping group. In the Oxford Midwives 1991 trial, it was unclear whether pilot data were included in the main trial data and whether or not data were collected in the same way.

In the study by Cernadas 2006, more than a quarter of the women included had caesarean births. This may mean data from this study are affected by neonatal clinicians attending the delivery. In the past, babies delivered by caesarean were routinely admitted to special, or neonatal intensive care. In this study, the number of caesarean births was balanced in the intervention and control groups so the impact of including data for these women is not clear.

In summary, trials were judged to be at moderate risk of bias, largely due to lack of reporting and therefore necessitating a high proportion of unclear judgements.

\section{Effects of interventions}

We included 15 trials involving a total of 3911 women and infant pairs.

Results are generally presented by whether uterotonics were given before or after cord clamping, or whether it was not stated whether a uterotonic was used.

\section{Primary}

\section{Severe postpartum haemorrhage $\geq 1000 \mathrm{~mL}$}

This outcome was measured in five trials with data for 2066 women. There were no significant differences between early and late cord clamping groups for severe postpartum haemorrhage (risk ratio (RR) $1.0495 \%$ confidence interval $(\mathrm{Cl}) 0.65$ to 1.65 , with a late clamping event rate (LCER) of $3.5 \%, \mathrm{I}^{2} 0 \%$ ). Overall, relatively few women experienced severe haemorrhage (unweighted percentages $3.6 \%$ versus $3.5 \%$ in the early and late clamping groups) and the $95 \% \mathrm{Cls}$ for this outcome were wide. There were no significant differences between subgroups depending on whether, and when uterotonics were administered (Analysis 1.1). All except one of these studies were assessed as being at low risk of bias for allocation concealment. 


\section{Maternal death or severe morbidity}

No trials in this review reported on maternal death or on severe maternal morbidity.

\section{Neonatal death}

There were very sparse data on neonatal death. In the study by Cernadas 2006, there were no neonatal deaths in either the early or late clamping groups and in the trial by van Rheenen 2007 there were four deaths with no significant difference between groups (RR $0.3795 \% \mathrm{Cl} 0.04$ to 3.41 , with a LCER of ${ }^{\sim} 1 \%, \mathrm{I}^{2}$ not applicable) (Analysis 1.2). Spears 1966 reported six neonatal deaths but these are described only as being randomly spread across the groups; no further explanation or detail is offered.

\section{Maternal Secondary Outcomes}

\section{Postpartum haemorrhage $\geq 500 \mathrm{~mL}$}

The timing of cord clamping was not shown to be of any statistical significance with regard to postpartum haemorrhage of $500 \mathrm{~mL}$ or more (RR $1.1795 \% \mathrm{Cl} 0.94$ to 1.44 , five trials, 2260 women).There was no evidence of differences between subgroups depending on the use and timing of uterotonic drugs (Analysis 1.3).

\section{Mean blood loss}

There were no significant differences in mean blood loss between women in early and late cord clamping groups; this outcome was reported in only two trials with data for 1345 women (mean difference (MD) $5.11 \mathrm{~mL} 95 \% \mathrm{Cl}-23.18$ to 33.39) (Analysis 1.4). There were no significant differences between subgroups relating to the timing of uterotonic drugs.

\section{Maternal postpartum haemoglobin}

Maternal haemoglobin values were not significantly different between women in the early and late cord clamping groups (MD $-0.12 \mathrm{~g} / \mathrm{dL}, 95 \% \mathrm{Cl}-0.30$ to 0.06 , three trials, 1128 women) at 24 to 72 hours after the birth; there were no significant differences between subgroups relating to the use of uterotonic drugs (Analysis 1.5).

\section{Need for blood transfusion}

In two trials, there were no statistically significant differences in need for blood transfusion between the early and late cord clamping groups (RR $1.0295 \% \mathrm{Cl} 0.44$ to 2.37 ; 1345 women) (Analysis 1.6) and there was no significant indication that this differed by whether uterotonics were given before or after clamping.

\section{Need for manual removal of placenta}

In two trials with 1515 women, no significant difference was seen between the early and late cord clamping groups for manual removal of placenta (RR $1.59,95 \% \mathrm{Cl} 0.78$ to 3.26 ) with no significant indication that this differed by whether the uterotonic drugs were given before of after the clamping (Analysis 1.7).

\section{Length of third stage of labour}

In two trials, neither instances of women experiencing third stage labour greater than 30 , nor 60 , minutes were significantly different between the early and late cord clamping groups (1345 women) (Analysis 1.8; Analysis 1.9).

\section{Therapeutic uterotonics}

McDonald 1996 showed no significant differences in the need for therapeutic administration of uterotonics between the early and late cord clamping groups (RR 0.94, 95\% $\mathrm{Cl} 0.74$ to 1.20 ; 963 women) (Analysis 1.10).

\section{Other Outcomes}

Other prespecified maternal outcomes including adverse effects (such as vomiting and headache) were not reported.

\section{Neonatal secondary outcomes}

\section{Apgar score}

Three trials reported on the number of babies with an Apgar score less than seven at five minutes; in one trial all babies had scores above seven (Philip 1973). For the two trials with estimable data there was no significant difference between the early and late cord clamping groups (McDonald 1996 and Spears 1966) (RR 1.23 95\% Cl 0.73 to 2.07; estimable data for 1342 neonates) (Analysis 1.11).

\section{Admission to special care baby nursery (SCN) or neonatal intensive care unit (NICU)}

This outcome was reported in four trials with data for 1675 infants. There was no significant difference seen between groups for SCN or NICU admission (RR 0.79, 95\% $\mathrm{Cl} 0.48$ to 1.31) (Analysis 1.12).

\section{Respiratory distress}

Three trials reported the number of infants showing signs of respiratory distress. There appeared to be considerable differences in reported event rates between studies for this outcome and so we presented a random-effects analysis.There was no strong evidence of differences between groups (RR $0.7095 \% \mathrm{Cl} 0.22$ to 2.19; 835 infants). Al-Tawil 2012 reported no events in either arm. In the trial by Cernadas 2006, event rates were relatively low (4/184 in the early clamping group versus $6 / 92$ in the late clamping group), whereas in the study by Spears 1966, distress was reported for a much greater number of infants (25/192 versus 22/187 respectively); this latter study may have reported less severe or more transient distress (Analysis 1.13).

\section{Jaundice requiring phototherapy}

This outcome was reported in seven trials with data for 2324 infants. Significantly fewer infants in the early cord clamping group required phototherapy for jaundice than in the late cord clamping group (RR $0.6295 \% \mathrm{Cl} 0.41$ to 0.96 , with a LCER of $<5 \%$, I2 5\%). This equates to $2.74 \%$ of infants in the early clamping group and $4.36 \%$ in the late clamping group, a risk difference of $<2 \%(95 \% \mathrm{Cl}-0.03$ to 0.00 ) (Analysis 1.14). In a subgroup analysis, there were no clear differences in outcomes according to use and timing of uterotonic drugs.

\section{Clinical jaundice}

The number of infants with clinical jaundice was reported in six trials with 2098 infants. The difference between early and late cord clamping for clinical jaundice did not reach statistical significance (RR $0.8495 \% \mathrm{Cl} 0.66$ to 1.07) (Analysis 1.15). 


\section{Polycythaemia}

No difference between the early and late cord clamping groups was detected for polycythaemia in five trials reporting this outcome (RR $0.3995 \% \mathrm{Cl} 0.12$ to $1.27 ; 1025$ infants) (Analysis 1.16).

\section{Cord haemoglobin $(\mathrm{g} / \mathrm{dL})$}

The early cord clamping group showed higher concentrations of cord haemoglobin than did the late clamping group (MD $0.41 \mathrm{~g} / \mathrm{dL}$ $95 \% \mathrm{Cl} 0.15$ to 0.66 , five trials, 696 infants) (Analysis 1.17).

\section{Newborn haemoglobin $(g / d L)$}

This outcome was reported for three trials with data for 671 infants. There were significantly lower infant haemoglobin concentrations at birth for babies in the in the early clamping group compared with those in the late clamping group (MD $-2.17 \mathrm{~g} / \mathrm{dL} 95 \% \mathrm{Cl}$ -4.06 to -0.28 ; random-effects model). This outcome showed very high heterogeneity (12 96\%) between trials with a significant interaction test indicating a more pronounced effect in the uterotonic subgroup compared with the subgroup where use of uterotonic was not specified (Analysis 1.18).

\section{Infant haemoglobin $(g / d L)$}

\section{- at 24-48 hours}

In four trials, the early cord clamping groups showed significantly lower infant haemoglobin concentrations 24 hours after birth than the late clamping groups (MD $-1.49 \mathrm{~g} / \mathrm{dL} 95 \% \mathrm{Cl}-1.78$ to $-1.21 ; 884$ infants) (Analysis 1.19).

\section{- three to six months}

Infant haemoglobin at three to six months was reported in six trials with 1115 infants. No statistically significant difference between early and late clamping was seen for all six trials combined (average MD $-0.15 \mathrm{~g} / \mathrm{dL} 95 \% \mathrm{Cl}-0.48$ to 0.19 ) (Analysis 1.20). The discrepancy between trials manifested as extremely high statistical heterogeneity (I2 84\%).

- low haemoglobin at three to six months

In four trials, infant anaemia at four months did not reach a statistically significant difference between early and late clamping (RR 1.05 95\% Cl 0.79 to 1.39; 954 infants) (Analysis 1.21).

\section{Infant haematocrit}

\section{- haematocrit values at 24 hours; and at three to five months}

One trial with 180 infants reported haematocrit values for infants at 24 hours and at three to five months of age. Haematocrit at 24 hours was significantly higher in the late, compared with the early clamping group (MD $-4.40 \% 95 \% \mathrm{Cl}-5.71$ to -3.09 ) but this effect did not persist at three to five months (MD $-0.4095 \% \mathrm{Cl}-1.48$ to 0.68 ; 160 infants) (Analysis 1.22).

\section{- low haematocrit at six hours (haematocrit <45\%)}

When measured as a haematocrit threshold greater than $45 \%$ in a single study, fewer infants in the late clamping group had anaemia compared with the early clamping group (RR $16.18,95 \% \mathrm{Cl} 2.05$ to 127.37; Cernadas 2006; 272 infants) (Analysis 1.23).
In this same study, this difference in favour of late clamping persisted at 24 to 48 hours (RR $6.03,95 \% \mathrm{Cl} 2.27$ to 16.07 ; Cernadas 2006; 268 infants) (Analysis 1.24).

\section{Infant iron deficiency at three to six months}

Five trials with 1152 infants reported data on infant iron deficiency at three to six months in a way that allowed us to include results in meta-analysis.

Infants in the late clamping group were significantly less likely to have iron deficiency (average RR $2.6595 \% \mathrm{Cl} 1.04$ to 6.73; with a LCER ranging from $0.5 \%$ to $70 \%,\left.\right|^{2} 82 \%$ ) (Analysis 1.25). However, there was high heterogeneity for this outcome and differences in effect size may be partly explained by variation in the way iron deficiency was defined in trials as well as when it was measured. Andersson 2011 defined iron deficiency as two or more indicators outside reference ranges (low ferritin, low mean cell volume, low transferrin saturation, high transferrin receptors); Cernadas 2006 and Chaparro 2006 as ferritin < $9 \mu \mathrm{g} / \mathrm{L}$; Al-Tawil 2012 as serum ferritin $<20 \mu \mathrm{g} / \mathrm{L}$; and van Rheenen 2007 as zinc-protoporphyrin (ZPP) $>80 \mu \mathrm{mol} / \mathrm{mol}$ haem. These and other studies (Geethanath 1997; Gupta 2002) reported other findings relating to infant iron stores; some of these data were presented in ways that did not allow us to include results in data and analyses tables (e.g. results reported as geometric means) and we have set out findings in an additional table (Table 1 ).

\section{Birthweight}

Twelve trials reported mean birthweight in a way that allowed us to include data in meta-analysis. (In addition, Saigal 1972 reported means and ranges and as it is not possible to convert ranges to SDs, we have not included data from this study in the overall analysis). The results showed a decreased birthweight in babies in the early cord clamping arm with a mean difference in birthweight of - 101.18 g $(95 \% \mathrm{Cl}-157.59$ to $-44.76,3139$ infants). We used a randomeffects model for this analysis in view of high heterogeneity (12 62\%) (Analysis 1.26).

\section{Not breastfed at discharge}

Nine studies with a total of 2950 babies included data on breastfeeding; at discharge; Jahazi 2008; McDonald 1996; Nelson 1980 and Oxford Midwives 1991 at one month, Cernadas 2006 at two months, van Rheenen 2007 at three months, Geethanath 1997 and Gupta 2002 at four months, and Chaparro 2006 and van Rheenen 2007 at six months. Overall, there were no significant differences between the groups at any time point (Analysis 1.27).

\section{Neonatal and child neurodevelopmental outcome}

To date, one trial has reported longer-term developmental outcomes for babies. In Andersson 2011, no significant differences between early and late cord clamping were seen for infants at four months of age in parental responses to the Ages and Stages questionnaire (ASQ) - overall scores MD $-1.4095 \% \mathrm{Cl}-7.31$ to 4.51; 365 infants. Four of the six ASQ components also showed no significant differences between groups with one (ASQ problemsolving) showing significantly higher (better) scores for the late clamping group and one (ASQ personal-social score) showing significantly higher (better) scores in the early clamping group (Analysis 1.28).

- low haematocrit at 24 to 48 hours (haematocrit < 45\%) 


\section{Neonatal and child infection}

In the same trial (Andersson 2011), a range of symptoms that may be associated with infection were reported for 360 infants in the first four months of life. None of these symptoms showed significant differences between the early and late cord clamping groups (Analysis 1.29)

\section{DISCUSSION}

\section{Summary of main results}

In this updated version of the review we have included 15 trials (involving a total of 3911 women and infant pairs) carried out in a number of countries over a long timeframe.

There were no significant differences seen between early and late cord clamping groups for the primary maternal outcome of severe postpartum haemorrhage or for the secondary outcomes of postpartum haemorrhage of $500 \mathrm{~mL}$ or more or mean blood loss. No included trials reported on maternal death or severe maternal morbidity. Maternal haemoglobin values were not significantly different between women in the early and late cord clamping groups in the days after giving birth.

No significant difference between early and late cord clamping was seen for the primary outcome of neonatal mortality or for most other neonatal morbidity outcomes. There was a significant (101 g mean) birthweight increase seen with late, compared with early, cord clamping. However, significantly fewer infants in the early cord clamping group required phototherapy for jaundice than in the late cord clamping group. Haemoglobin concentration in infants at 24 to 48 hours was increased in the late cord clamping group. This difference in haemoglobin concentration was not seen at subsequent assessments. However, improvement in iron stores was significant (with infants in the early cord clamping over twice as likely (risk ratio (RR) $2.6595 \%$ confidence interval (CI) 1.04,6.75) to be iron deficient at three to six months compared with infants whose cord clamping was delayed. In the only trial to report longerterm neurodevelopmental outcomes so far, no overall differences between early and late clamping were identified at four months.

\section{Overall completeness and applicability of evidence}

Although reviews such as Hutton 2007 and van Rheenen 2006 have highlighted beneficial effects from delayed cord clamping compared with early cord clamping, maternal wellbeing has not been a major focus for reviews or trials of cord clamping. This is an important gap as women experiencing ill health postpartum may be less able to mother as effectively which ultimately reflects on the health and wellbeing of the newborn infant and family life in general.

The ability of the review to reach conclusive findings and evidence to guide future practice was limited by differences in variables such as the lengths of timing for both early and late cord clamping, as well as the inconsistent coverage of outcomes between trials. In addition, the use of prophylactic uterotonics was not always well described in the trials.

The benefits and harms seen for delayed cord clamping are compatible with the same mechanism of an increased amount of red blood cells for the infant. Additional red blood cells can improve the infant's iron stores, but this also has the potential to overload the newborn's metabolism, leading to increased levels of bilirubin and in very severe cases, severe jaundice and later kernicterus (AAP 2004). The potential for harm would need to be weighed up by clinicians in context with the settings in which they work. For instance, if treatment for moderate to severe jaundice was not easily accessible and there was a risk of causing further complications for the infant, late cord clamping may be less optimal. On the other hand, increasing iron stores in infants through delayed cord clamping may be particularly beneficial in resourcepoor settings where severe anaemia is common (McDonald 2007).

The World Health Organization has recently recommended that "the cord should not be clamped earlier than is necessary" and notes that this would normally take around three minutes. They have graded this recommendation as a "weak recommendation, low quality evidence" (Baker 2010; Stolzfus 2011; WHO 2012b. This recommendation is compatible with the evidence although this update of the review contains some additional data not considered by WHO 2012b, which increases the level of confidence in recommending later cord clamping.

\section{Quality of the evidence}

The overall methodological quality of the trials contributing data to the review was moderate or high. While none of the studies was assessed as being at high risk of bias for most domains, several trials did not provide clear information on methods. Nine of the 15 included trials used methods to conceal allocation at the point of randomisation that we assessed as low risk of bias. Lack of blinding was a problem in all of the included studies; blinding women and clinical staff to randomised group is not feasible with this type of intervention. The impact of lack of blinding is difficult to judge. Knowledge of allocation could have affected other aspects of care and the assessment of many outcomes, particularly blood loss, could, in theory, have been unconsciously affected by people's beliefs. Haemoglobin assessment would usually be performed by a technician who would be blind to the trial allocation. Seven of the studies reported that an attempt was made to blind the collection of at least some of the outcome data to reduce detection bias (Al-Tawil 2012; Andersson 2011; Cernadas 2006; McDonald 1996; Oxford Midwives 1991; Nelson 1980; van Rheenen 2007). Although loss to follow-up was not always described, most of the outcomes related to the time close to birth when attrition was likely to have been low.

For most of the outcomes reported in the review, data were limited. For some outcomes event rates were low and even where we pooled data from several studies there was insufficient power to detect possible differences between groups. For some outcomes only a small number of studies contributed data, and this again, led to reduced confidence in the effect estimates. An added problem was the lack of consistency in the outcomes reported and the way outcomes were measured in different studies. For example, for infant anaemia and iron status, studies examined different outcomes, used different definitions or cut-off points, measured outcomes in different ways or at different time points. These differences meant that pooled estimates could not be obtained.

Some important outcomes were not reported in any of the included studies and so far, only one of the included studies has reported infant neurological outcomes or longer-term neurological development. 


\section{Potential biases in the review process}

We are aware that there is the potential to introduce bias at every stage in the review process and we took steps to minimise bias. At least two review authors independently assessed each study for possible inclusion, and carried out data extraction and assessment of study quality for included studies. Assessing risk of bias is a matter of judgment rather than an exact science and it is possible that a different review team may have made different decisions.

One of the review team was an author on one of the included trials (McDonald 1996) and was not involved in carrying out data extraction or assessing risk of bias for this trial.

\section{Agreements and disagreements with other studies or reviews}

A recent review of active management of the third stage of labour (including early cord clamping), showed a reduction in postpartum haemorrhage greater than $1000 \mathrm{~mL}$ although the outcomes for infants were less clear, and the authors recommended that the individual components of third-stage management should be examined separately (Begley 2011). Recent WHO guidelines recommend cord clamping between one to three minutes after the birth (WHO 2012b). While this review concentrated on term babies, it is of interest that a recently updated Cochrane review of early versus later cord clamping in preterm infants (Rabe 2012) also suggested that there may be benefits to the infant associated with later clamping. The conclusions of that review were that delaying clamping reduces the need for blood transfusion, risk of intraventricular haemorrhage and necrotising enterocolitis in this preterm population although effects on the mother and other important infant outcomes were not clear.

\section{AUTHORS' CONCLUSIONS}

\section{Implications for practice}

A more liberal approach to delaying clamping of the umbilical cord in healthy term infants appears to be warranted, particularly in light of growing evidence that delayed cord clamping may be of benefit in the longer term in promoting better iron stores in infants, as long as access to treatment for jaundice requiring phototherapy is easily accessible. Clinical implications for improvement in iron stores would be enhanced if follow-up data were available for child development.

\section{Implications for research}

Future studies should have adequate power to be able to detect the true advantages and disadvantages of cord clamping on outcomes; they should also report fully details of methods to allow assessment of risk of bias. Future studies should compare maternal outcomes such as PPH, longer term (six to 12 months) postpartum followup on iron status, physical and psychological health, as well as short- and longer-term neonatal and infant outcomes such as neurodevelopment.

\section{ACKNOWLEDGEMENTS}

Dr Chad Andersen, Consultant Neonatologist in the Department of Perinatal Medicine at the Children's Youth and Women's Health Service in Adelaide, Australia, who provided valuable feedback and comments on an earlier version of the review.

We wish to thank the Cochrane Pregnancy and Childbirth Review Group, particularly Sonja Henderson, Lynn Hampson and the Consumer Panel. We also wish to thank Jo Abbott and Shane Higgins who helped to write the protocol and carried out some of the data extraction for the original review.

The National Institute for Health Research (NIHR) is the largest single funder of the Cochrane Pregnancy and Childbirth Group. The views and opinions expressed therein are those of the authors and do not necessarily reflect those of the NIHR, NHS or the Department of Health. 


\section{R E F E R E N C E S}

\section{References to studies included in this review}

\section{Al-Tawil 2012 \{published data only\}}

Al-Tawil MM, Abdel-Aal MR, Kaddah MA. A randomized controlled trial on delayed cord clamping and iron status at 3-5 months in term neonates held at the level of maternal pelvis. Journal of Neonatal-Perinatal Medicine 2012;5(4):319-26.

\section{Andersson 2011 \{published and unpublished data\}}

Andersson O, Domellöf M, Andersson D, Hellström-Westas L. Effect of delayed cord clamping on neurodevelopment and infection at four months of age: a randomised trial. Acta Paediatrica 2013;102:525-31.

Andersson O, Hellstrom-Westas D, Claussen J, Domellof M. Effects of early vs. delayed umbilical cord clamping on cord blood sampling and maternal postpartum hemorrhage a randomized trial. Pediatric Academic Societies and Asian Society for Pediatric Research Joint Meeting; 2011 April 30-May 3; Denver, Colorado, USA. 2011:3535.1.

Andersson O, Hellstrom-Westas L, Andersson D, Domellof M. Early versus late cord clamping: neonatal outcomes and iron status at 4 months in Swedish infants. Pediatric Academic Societies' 2010 Annual Meeting; 2010 May 1-4; Vancouver, Canada. 2010.

* Andersson O, Hellstrom-Westas L, Andersson D, Domellof M. Effect of delayed versus early umbilical cord clamping on neonatal outcomes and iron status at 4 months: a randomised controlled trial. BMJ 2011;343:d7157.

Andersson O, Hellström-Westas L, Andersson D, Clausen J, Domellöf M. Effects of delayed compared with early umbilical cord clamping on maternal postpartum haemorrhage and cord blood gas sampling: a randomized trial. Acta Obstetrica et Gynelogica Scandinavica 2013;92(5):567-74.

\section{Cernadas 2006 \{published data only\}}

Ceriani Cernadas JM, Carroli G, Otano L, Pellegrini L, Mariani GL, Ferreira M, et al. Effect of timing of cord clamping on postnatal hematocrit values and clinical outcome in term infants. A randomized controlled trial [abstract]. Pediatric Research 2004;55 Suppl:67.

Ceriani Cernadas JM, Carroli G, Pellegrini L, Ferreira M, Ricci C, Casas $\mathrm{O}$, et al. The effect of early and delayed umbilical cord clamping on ferritin levels in term infants at six months of life: a randomized, controlled trial. Archivos Argentinos de Pediatria 2010;108(3):201-8.

* Ceriani Cernadas JM, Carroli G, Pellegrini L, Otano L, Ferreira M, Ricci C, et al. The effect of timing of cord clamping on neonatal venous hematocrit values and clinical outcome at term: a randomized, controlled trial. Pediatrics 2006;117:779-86.

Ceriani J, Ricci C, Ferreira M. Effect of timing of cord clamping on postnatal hematocrit values and clinical outcome in term infants. A randomized, controlled trial. Pediatric Research 2005;57(6):922.
Chaparro 2006 \{published data only\}

Chaparro CM, Fornes R, Neufeld LM, Alavez GT, Cedillo RE, Dewey KG. Early umbilical cord clamping contributes to elevated blood lead levels among infants with higher lead exposure. Journal of Pediatrics 2007;151:506-12.

* Chaparro CM, Neufeld LM, Alavez GT, Cedillo RE-L, Dewey KG. Effect of timing of umbilical cord clamping on iron status in Mexican infants: a randomised controlled trial. Lancet 2006;367:1997-2004

\section{Emhamed 2004 \{published data only\}}

Emhamed MO, van Rheenen P, Brabin BJ. The early effects of delayed cord clamping in term infants born to Libyan mothers. Tropical Doctor 2004;34:218-22.

\section{Geethanath 1997 \{published data only\}}

Geethanath RM, Ramji S, Thirupuram S, Rao YN. Effect of timing of cord clamping on the iron status of infants at 3 months. Indian Pediatrics 1997;34(2):103-6.

Gupta 2002 \{published data only\}

Gupta R, Ramji S. Effect of delayed cord clamping on iron stores in infants born to anemic mothers: a randomized controlled trial. Indian Pediatrics 2002;39(2):130-5.

\section{Jahazi 2008 \{published data only\}}

Jahazi A, Kordi M, Mirbehbahani NB, Mazloom SR. The effect of early and late umbilical cord clamping on neonatal hematocrit. Journal of Perinatology 2008;28(8):523-5.

\section{McDonald 1996 \{published and unpublished data\}}

McDonald S. Timing of interventions in the third stage of labour. International Confederation of Midwives 24th Triennial Congress; 1996 May 26-31; Oslo, Norway. 1996:143.

McDonald S. Timing of interventions in the third stage of labour. Proceedings of the 14th Annual Congress of the Australian Perinatal Society in conjunction with the New Zealand Perinatal Society; 1996 March 24-27; Adelaide, Australia. 1996:A23.

* McDonald SJ. Management in the third stage of labour [dissertation]. Perth: University of Western Australia, 1996.

\section{Nelson 1980 \{published data only\}}

Nelson NM, Enkin MW, Saigal S, Bennett KJ, Milner R, Sackett DL. A randomized clinical trial of the Leboyer approach to childbirth. New England Journal of Medicine 1980;302(12):655-60.

Saigal S, Nelson NM, Bennett KJ, Enkin MW. Observations on the behavioral state of newborn infants during the first hour of life. A comparison of infants delivered by the Leboyer and conventional methods. American Journal of Obstetrics and Gynecology 1981;139(6):715-9.

\section{Oxford Midwives 1991 \{published data only\}}

Oxford Midwives Research Group. A study of the relationship between the delivery to cord clamping interval and the time of cord separation. Midwifery 1991;7:167-76. 
Philip 1973 \{published data only\}

Philip AGS. Further observations on placental transfusion. Obstetrics and Gynecology 1973;42(3):334-43.

Saigal 1972 \{published data only\}

* Saigal S, O'Neill A, Surainder Y, Chua LB, Usher R. Placental transfusion and hyperbilirubinemia in the premature. Pediatrics 1972;49:406-19.

Saigal S, Usher RH. Symptomatic neonatal plethora. Biology of the Neonate 1977;32:62-72.

\section{Spears 1966 \{published data only\}}

Spears RL, Anderson GV, Brotman S, Farrier J, Kwan J, Masto A, et al. The effect of early vs late cord clamping on signs of respiratory distress. American Journal of Obstetrics and Gynecology 1966;95:564-8.

\section{van Rheenen 2007 \{published data only\}}

van Rheenen P, de Moor L, Eschbach S, de Grooth H, Brabin B. Delayed cord clamping and haemoglobin levels in infancy: a randomised controlled trial in term babies. Tropical Medicine and International Health 2007;12(5):603-15.

\section{References to studies excluded from this review}

\section{Abdel Aziz 1999 \{published data only\}}

Abdel Aziz SF, Shaheen MY, Hussein S, Suliman MS. Early cord clamping and its effect on some haematological determinants of blood viscosity in neonates. www.obgyn.net/pb/articles/ cordclamping_aziz_0699.htm (accessed May 2007).

Begley 1990 \{published data only\}

Begley CM. A comparison of 'active' and 'physiological' management of the third stage of labour. Midwifery 1990;6(1):3-17.

\section{Botha 1968 \{published data only\}}

Botha MC. The management of the umbilical cord in labour. South African Journal of Obstetrics and Gynaecology 1968;6:30-3.

\section{Buckels 1965 \{published data only\}}

Buckels LJ, Usher R. Cardiopulmonary effects of placental transfusion. Journal of Pediatrics 1965;67:239-46.

\section{Colozzi 1954 \{published data only\}}

Colozzi AE. Clamping of the umbilical cord; its effect on the placental transfusion. New England Journal of Medicine 1954;250(15):629-32.

\section{Daily 1970 \{published data only\}}

Daily W, Olsson T, Victorin L. Transthoracic impedance: V. Effects of early and late clamping of the umbilical cord with special reference to the ratio air-to-blood during respiration. Acta Paediatrica Scandinavica 1970;207(Suppl):57-72.

\section{De Paco 2011 \{published data only\}}

De Paco C, Florido J, Garrido MC, Prados S, Navarrete L. Umbilical cord blood acid-base and gas analysis after early versus delayed cord clamping in neonates at term. Archives of Gynecology and Obstetrics 2011;283(5):1011-4.

Duckman 1953 \{published data only\}

Duckman S, Merk H, Lehmann WX, Regan E. The importance of gravity in delayed ligation of the umbilical cord. American Journal of Obstetrics and Gynecology 1953;66(6):1214-33.

Dunn 1966 \{published data only\}

Dunn PM, Fraser ID, Raper AB. Influence of early cord ligation on the transplacental passage of foetal cells. Journal of Obstetrics and Gynaecology of the British Commonwealth 1966;73:757-60.

Emmanouilides 1971 \{published data only\}

Emmanouilides GC, Moss AJ. Respiratory distress in the newborn: effect of cord clamping before and after onset of respiration. Biology of the Neonate 1971;18(5):363-8.

\section{Erickson-Owens 2012 \{published data only\}}

Erickson-Owens DA. Milking the umbilical cord at term cesarean section: effect on hemoglobin levels in the first 48 hours of life. Pediatric Academic Societies' 2010 Annual Meeting; 2010 May 1-4; Vancouver, Canada. 2010.

* Erickson-Owens DA, Mercer JS, Oh W. Umbilical cord milking in term infants delivered by cesarean section: A randomized controlled trial. Journal of Perinatology 2012;32(8):580-4.

Erkkola 1984 \{published data only\}

Erkkola R, Kero P, Kanto J, Korvenranta H, Nanto V, Peltonen T. Delayed cord clamping in cesarean section with general anesthesia. American Journal of Perinatology 1984;1(2):165-9.

Grajeda 1997 \{published data only\}

Grajeda R, Perez-Escamilla R, Dewey K. Delayed clamping of the umbilical cord improves hematologic status of Guatemalan infants at 2 mo of age. American Journal of Clinical Nutrition 1997;65:425-31.

\section{Greenberg 1967 \{published data only\}}

Greenberg M, Vuorenkoski V, Partanen TJ, Lind J. Behavior and cry patterns in the first two hours of life in early and late clamped newborn. Annales Paediatriae Fenniae 1967;13(2):64-70.

\section{Johansen 1971 \{published data only\}}

Johansen JK, Schacke E, Sturup AG. Feto-maternal transfusion and free bleeding from the umbilical cord. Acta Obstetricia et Gynecologica Scandinavica 1971;50:193-5.

Kemp 1971 \{published data only\}

Kemp J. A review of cord traction in the third stage of labour from 1963 to 1969. Medical Journal of Australia 1971;1(17):899-903.

Khan 1997 \{published data only\}

Khan GQ, John IS, Wani S, Doherty T, Sibai BM. Controlled cord traction versus minimal intervention techniques in delivery of the placenta: a randomized controlled trial. American Journal of Obstetrics and Gynecology 1997;177(4):770-4. 
Kliot 1984 \{published data only\}

Kliot D, Silverstein L. Changing maternal and newborn care. A study of the Leboyer approach to childbirth management. New York State Journal of Medicine 1984;84:169-74.

\section{Lanzkowsky 1960 \{published data only\}}

Lanzkowsky P. Effects of early and late clamping of umbilical cord on infant's haemoglobin level. BMJ 1960;2:1777-82.

\section{Linderkamp 1992 \{published data only\}}

* Linderkamp O, Nelle M, Kraus M, Zilow EP. The effect of early and late cord-clamping on blood viscosity and other hemorheological parameters in full-term neonates. Acta Paediatrica 1992;81(10):745-50.

Nelle M, Zilow EP, Kraus M, Bastert G, Linderkamp O. The effect of Leboyer delivery on blood viscosity and other hemorheologic parameters in term neonates. American Journal of Obstetrics and Gynecology 1993;169:189-93.

\section{Navaneethakrishnan 2010 \{published data only\}}

* Navaneethakrishnan R, Anderson A, Holding S, Atkinson C, Lindow SW. A randomised controlled trial of placental cord drainage to reduce feto-maternal transfusion. European Journal Obstetrics \& Gynecology and Reproductive Biology 2010;149(1):27-30.

Navaneethakrishnan R, Anderson A, Holding S, Atkinson C, Lindow SW. A randomised controlled trial of placental drainage to reduce feto-maternal transfusion [abstract]. Journal of Obstetrics and Gynaecology 2007;27(Suppl 1):S67.

\section{Nelle 1996 \{published data only\}}

* Nelle M, Kraus M, Bastert G, Linderkamp O. Effects of Leboyer childbirth on left- and right systolic time intervals in healthy term neonates. Journal of Perinatal Medicine 1996;24(5):513-20.

Nelle M, Zilow EP, Bastert G, Linderkamp O. Effect of Leboyer childbirth on cardiac output, cerebral and gastrointestinal blood flow velocities in full-term neonates. American Journal of Perinatology 1995;12:212-6.

\section{Newton 1961 \{published data only\}}

Newton M, Moody AR. Fetal and maternal blood in the human placenta. Obstetrics \& Gynecology 1961;18:305-8.

* Newton M, Mosey LM, Egli GE, Gifford WB, Hull CT. Blood loss during and immediately after delivery. Obstetrics \& Gynecology 1961;17:9-18.

\section{Prendiville 1988 \{published data only\}}

Prendiville WJ, Harding JE, Elbourne DR, Stirrat GM. The Bristol third stage trial: active versus physiological management of third stage of labour. BMJ 1988;297:1295-300.

\section{Rogers 1998 \{published data only\}}

* Rogers J, Wood J, McCandlish R, Ayers S, Truesdale A, Elbourne D. Active versus expectant management of third stage of labour: the Hinchingbrooke randomised controlled trial. Lancet 1998;351(9104):693-9.
Wood J, Rogers J, Elbourne D, McCandish R, Truesdale A. The Hinchingbrooke third stage trial. International Conferderation of Midwives 24th Triennial Congress, Oslo. 26-31 May 1996.

Schindler 1981 \{published data only\}

Schindler AE, Schach R. [Clamped umbilical cord. Effect on the puerperium and the newborn's hematocrit]. Fortschritte der Medizin 1981;99(44):1849-51.

\section{Siddall 1953 \{published data only\}}

Siddall RS, Richardson RP. Milking or stripping the umbilical cord; effect on vaginally delivered babies. Obstetrics and Gynecology 1953;1(2):230-3.

\section{Sorrells-Jones 1982 \{published data only\}}

Sorrell-Jones J. A comparison of the effects of the Leboyer delivery and modern 'routine' childbirth. Personal communication with the Cochrane Pregnancy and Childbirth Group 1982.

\section{Taylor 1963 \{published data only\}}

Taylor PM, Bright NH, Birchard EL. Effect of early vs delayed clamping of the umbilical cord on the clinical condition of the newborn infant. American Journal of Obstetrics and Gynecology 1963;86:893-8.

\section{Terry 1970 \{published data only\}}

Terry MF. A management of the third stage to reduce fetomaternal transfusion. Journal of Obstetrics and Gynaecology of the British Commonwealth 1970;77(2):129-32.

\section{Thilaganathan 1993 \{published data only\}}

Thilaganathan B, Cutner A, Latimer J, Beard R. Management of the third stage of labour in women at low risk of postpartum haemorrhage. European Journal of Obstetrics, Gynecology and Reproductive Biology 1993;48(1):19-22.

\section{Walsh 1968 \{published data only\}}

Walsh SZ. Maternal effects of early and late clamping of the umbilical cord. Lancet 1968;1(7550):996-7.

Walsh 1969 \{published data only\}

Walsh SZ. Early clamping versus stripping of cord: comparative study of electrocardiogram in neonatal period. British Heart Journal 1969;31(1):122-6.

\section{Whipple 1957 \{published data only\}}

Whipple GA, Thomas MD, Sisson RC, Lund CJ. Delayed ligation of the umbilical cord: its influence on the blood volume of the newborn. Obstetrics and Gynecology 1957;10(6):603-10.

\section{Wu 1960 \{published data only\}}

Wu PC, Ku TS. Early clamping of the umbilical cord: a study of its effect on the infant. Chinese Medical Journal 1960;80:351-5.

\section{Yao 1971 \{published data only\}}

Yao AC, Lind J, Vuorenkoski V. Expiratory grunting in the late clamped normal neonate. Pediatrics 1971;48(6):865-70. 
Yao 1977 \{published data only\}

Yao AC, Lind J. Effect of early and late cord clamping on the systolic time intervals of the newborn infant. Acta Paediatricia Scandinavica 1977;66(4):489-93.

\section{References to studies awaiting assessment}

Jaleel 2009 \{published data only\}

Jaleel R, Deeba F, Khan A. Timing of umbilical cord clamping and neonatal haematological status. Journal of the Pakistan Medical Association 2009;59(7):468-70.

\section{Li 2012 \{published data only\}}

Li N, Yang LC, Wu Q, Han CC, Wang L, Rong L, et al. [The effects of iron stores and growth of delayed umbilical cord clamp timing on term breastfed infants at 4 months]. Zhonghua $Y u$ Fang Yi Xue Za Zhi 2012;46(4):303-6.

\section{Nardozza 2012 \{published data only\}}

Nardozza LMM, Mazzola JB, Lopes CD, Meleti D, Hatanaka AR, Araujo Jnr E, et al. Evaluation of fetal red blood cells for passage of the maternal circulation during afterbirth by Kleihauer Betke test. Journal of Perinatal Medicine 2012;39 Suppl:Abstract no. 187.

\section{Ping 2010 \{published data only\}}

Ping HS. Effect of umbilical cord clamping time on newborns. http://clinicaltrials.gov/ct2/show/NCT01029496 (accessed 12 June 2010).

\section{References to ongoing studies}

Beal 2006 \{unpublished data only\}

Beal JM. Timing of cord clamping and neonatal hemoglobin. http://clinicaltrials.gov/ct2/show/record/NCT00371228 (accessed 13 February 2008).

\section{Hanson 2012 \{published data only\}}

Hanson M, Morris P, Kilburn C, Lennox R, Szabo F, Bull A, et al. Effect of delayed cord clamping on the haemoglobin levels of term newborn aboriginal infants from remote aboriginal communities: A pilot randomised controlled trial. Journal of Paediatrics and Child Health 2012;48(Suppl 1):140.

\section{Additional references}

\section{AAP 2004}

American Academy of Pediatrics Subcommittee on Hyperbilirubinemia. Management of hyperbilirubinemia in the newborn infant 35 or more weeks of gestation. Pediatrics 2004;114(1):297-316.

\section{Baker 2010}

Baker RD, Greer FR. Diagnosis and prevention of iron deficiency and iron deficiency anaemia in infants and young children (0-3 years of age). Paediatrics 2010;126(5):1040-50.

\section{Baskett 1992}

Baskett TF. Management of the third stage of labour: a survey of practice among Canadian obstetricians. Journal of the Society of Obstetricians \& Gynaecologists of Canada 1992;14:61-4.

\section{Begley 2011}

Begley CM, Gyte GML, Devane D, McGuire W, Weeks A. Active versus expectant management for women in the third stage of labour. Cochrane Database of Systematic Reviews 2011, Issue 11. [DOI: 10.1002/14651858.CD007412.pub3]

\section{Beischer 1986}

Beischer NA, Mackay EV. Obstetrics and the Newborn. Eastbourne: Bailliere Tindall, 1986.

\section{Bonnar 2000}

Bonnar J. Massive obstetric haemorrhage. Baillière's Clinical Obstetrics and Gynaecology 2000;14(1):1-18.

\section{Brucker 2001}

Brucker MC. Management of the third stage of labor: an evidence-based approach. Journal of Midwifery and Women's Health 2001;46(6):381-92.

\section{Burchell 1980}

Burchell RC. Postpartum haemorrhage. In: Quilligan ES editor(s). Current Therapy in Obstetrics and Gynecology. Philadelphia: WB Saunders, 1980.

\section{Cotter 2001}

Cotter A, Ness A, Tolosa J. Prophylactic oxytocin for the third stage of labour. Cochrane Database of Systematic Reviews 2004 Issue 1. [DOI: 10.1002/14651858.CD001808]

\section{Gülmezoglu 2007}

Gülmezoglu AM, Forna F, Villar J, Hofmeyr GJ. Prostaglandins for prevention of postpartum haemorrhage. Cochrane Database of Systematic Reviews 2007, Issue 3. [DOI: 10.1002/14651858.CD000494.pub3]

\section{Harbord 2006}

Harbord RM, Egger M, Sterne JA. A modified test for smallstudy effects in meta-analyses of controlled trials with binary endpoints. Statistics in Medicine 2006;25(20):3443-57.

\section{Higgins 2011}

Higgins JPT, Green S, editors. Cochrane Handbook for Systematic Reviews of Interventions Version 5.1.0 [updated March 2011]. The Cochrane Collaboration, 2011. Available from www.cochrane-handbook.org.

\section{Hutton 2007}

Hutton EK, Hassan ES. Late vs early clamping of the umbilical cord in full-term neonates. JAMA 2007;297(11):1241-52.

\section{ICM/FIGO 2006}

Prevention and Treatment of Post-partum Haemorrhage; New Advances for Low Resource Settings: Joint Statement. International Confederation of Midwives (ICM); International Federation of Gynaecology and Obstetrics (FIGO) 2006, 
issue www.pphprevention.org/files/FIGO-ICM_Statement_ November2006_Final.pdf.

\section{Inch 1985}

Inch S. Management of the third stage of labour: another cascade of intervention?. Midwifery 1985;1:114-22.

\section{Kwast 1991}

Kwast BE. Postpartum haemorrhage: its contribution to maternal mortality. Midwifery 1991;7:64-70.

\section{Lapido 1972}

Ladipo OA. Management of third stage of labour, with particular reference to reduction of feto-maternal transfusion. British Medical Journal 1972;1(5802):721-3.

\section{Loke 2008}

Loke YL, Price D, Herxheimer A on behalf of the Cochrane Adverse Effects Methods Groups. Higgins JPT, Green S (editors). Cochrane Handbook for Systematic Reviews of Interventions Version 5.1.0 [updated March 2011]. The Cochrane Collaboration, 2011. Available from www.cochranehandbook.org.

\section{McDonald 2003}

McDonald S. Physiology and management of the third stage of labour. In: Fraser D, Cooper M editor(s). Myles Textbook for Midwives. 14th Edition. Edinburgh: Churchill Livingstone, 2003.

\section{McDonald 2007}

McDonald S. Management of the third stage of labor. Journal of Midwifery and Women's Health 2007;52:254-61.

\section{Mercer 2001}

Mercer JS. Current best evidence: a review of the literature on umbilical cord clamping. Journal of Midwifery \& Women's Health 2001;46(6):402-14

\section{Mercer 2006}

Mercer JS. Current best evidence: a review of the literature on umbilical cord clamping. In: Wickham S editor(s). Midwifery: Best Practice. Vol. 4, Edinburgh: Elsevier, 2006:114-29.

\section{Moerschel 2008}

Moerschel SK, Cianciaruso LB, Tracy LR. A practical approach to neonatal jaundice. American Family Physician 2008;77(9):1255.

\section{Palethorpe 2010}

Palethorpe RJ, Farrar D, Duley L. Alternative positions for the baby at birth before clamping the umbilical cord. Cochrane Database of Systematic Reviews 2010, Issue 10. [DOI: 10.1002/14651858.CD007555.pub2]

\section{Patterson 1994}

Patterson A, Davis J, Gregory M, Holt S, Pachulski A, Stamford D, et al. A study of the effects of low haemoglobin on postnatal women. Midwifery 1994;10:77-86.

\section{Prendiville 1989}

Prendiville W, Elbourne D. Care during the third stage of labour. In: Chalmers I, Enkin M, Keirse MJNC editor(s). Effective Care in Pregnancy and Childbirth. Oxford: Oxford University Press, 1989:1145-69.

\section{Prendiville 2000}

Prendiville WJ, Elbourne D, McDonald S. Active versus expectant management in the third stage of labour.

Cochrane Database of Systematic Reviews 2000, Issue 3. [DOI: 10.1002/14651858.CD000007]

\section{Rabe 2012}

Rabe H, Diaz-Rossello J, Duley L, Dowswell T. Effect of timing of umbilical cord clamping and other strategies to influence placental transfusion at preterm birth on maternal and infant outcomes. Cochrane Database of Systematic Reviews 2012, Issue 8. [DOI: 10.1002/14651858.CD003248.pub3]

\section{RevMan 2011 [Computer program]}

The Nordic Cochrane Centre, The Cochrane Collaboration. Review Manager (RevMan). Version 5.1. Copenhagen: The Nordic Cochrane Centre, The Cochrane Collaboration, 2011.

\section{Smith 2006}

Smith J, Brennan BG. Management of the third stage of labor. EMedicine from WebMD (last updated 27 June 2006) (accessed 28 January 2007).

\section{Stolzfus 2011}

Stolzfus RJ. Iron interventions for women and children in lowincome countries. Journal of Nutrition 2011;141(4):756S-762S.

\section{UN 2010}

United Nations. Millennium Development Goals Report. New York: United Nations, 2010.

\section{UNICEF 2002}

UNICEF. Maternal mortality. http://www.childiinfo.org/eddb/ mat_mortal/index.htm (accessed 24 October 2002).

\section{van Rheenen 2004}

van Rheenen P, Brabin BJ. Late umbilical cord clamping as an intervention for reducing iron deficiency in term infants in developing and industrialised countries: a systematic review. Annals of Tropical Medicine 2004;24(1):3-16.

\section{van Rheenen 2006}

van Rheenen P, Brabin BJ. A practical approach to timing cord clamping in resource poor settings. BMJ 2006;333:954-8.

\section{WHO 1990}

World Health Organization. The prevention and management of postpartum haemorrhage. WHO report of technical working group. Report No. WHO/MCH/90.7. Geneva: WHO, 1990.

\section{WHO 1996}

World Health Organization. Care in Normal Birth. Geneva: WHO, 1996.

\section{WHO 1998 a}

World Health Organization. Postpartum Care of the Mother and Newborn: a Practical Guide. Geneva: WHO, 1998. 


\section{WHO 1998b}

World Health Organization. Care of the Umbilical Cord: a Review of the Evidence. Geneva: WHO, 1998.

\section{WHO 2000}

World Health Organization. Managing Complications in Pregnancy and Childbirth: a Guide for Midwives and Doctors. Geneva: WHO, 2000.

\section{WHO 2002}

World Health Organization. Making pregnancy safer (MPR). http://www.who.int/reproductive-health/mps/index.htm (accessed 24 October 2002).

\section{WHO 2007}

World Health Organization, Department of Making Pregnancy Safer. WHO recommendations for the prevention of postpartum haemorrhage. Geneva: WHO, 2007.

\section{WHO 2012}

WHO, UNICEF, UNFPA, World Bank. Trends in Maternal Mortality: 1990 to 2010. Geneva: WHO, 2012.

\section{WHO 2012b}

World Health Organization. WHO Recommendations for the Prevention and Treatment of Postpartum Haemorrhage. Geneva: WHO, 2012

\section{Winter 2007}

Winter C, Macfarlane A, Deneux-Tharaux C, Zhang W-H, Alexander S, Brocklehurst $\mathrm{P}$, et al. Variations in policies for

\section{CHARACTERISTICS OFSTUDIES}

Characteristics of included studies [ordered by study ID] management of the third stage of labour and the immediate management of postpartum haemorrhage in Europe. BJOG: an international journal of obstetrics and gynaecology 2007;114:845-54.

\section{Yao 1974}

Yao AC, Lind J. Placental transfusion. American Journal of Diseases of Children 1974;127:128-41.

\section{References to other published versions of this review McDonald 2003a \\ McDonald SJ, Abbott JM. Effect of timing of umbilical cord clamping of term infants on maternal and neonatal outcomes. Cochrane Database of Systematic Reviews 2003, Issue 1. [DOI: 10.1002/14651858.CD004074]}

\section{McDonald 2008}

McDonald SJ, Middleton P. Effect of timing of umbilical cord clamping of term infants on maternal and neonatal outcomes. Cochrane Database of Systematic Reviews 2008, Issue 2. [DOI: 10.1002/14651858.CD004074.pub2]

\section{Wood 1996}

Wood J, Rogers J, Elbourne D, McCandlish R, Truesdale A. The Hinchingbrooke third stage trial. International Confederation of Midwives 24th Triennial Congress; 1996 May 26-31; Oslo, Norway. 1996:140.

* Indicates the major publication for the study

\section{Al-Tawil 2012}

Methods Randomised controlled trial, 2 arms with individual randomisation.

Participants Setting: 180 women giving birth at a hospital in Saudi Arabia between 2010-11.

Inclusion criteria: Multigravid women who had received adequate antenatal care, with singleton, term pregnancy and without underlying medical disease of pregnancy complications and planning a normal vaginal delivery.

Exclusion criteria: Women who did not deliver vaginally, small for gestational age infants or with birthweight below $2500 \mathrm{~g}$, neonates needing resuscitation or with respiratory difficulties, sepsis or congenital anomalies.

Interventions Early clamping: (90 women) immediate cord clamping (within 15 secs).

Delayed clamping: (90 women) delayed cord clamping (estimated from the time of shoulder delivery) with cord clamping after 3 minutes. The baby was put on the mother's abdomen until the placenta was delivered. (If during the three minutes delay the infant showed any sign of compromise the cord was cut immediately to allow resuscitation.)

Administration of uterotonic not clear. 
Al-Tawil 2012 (Continued)

At 24 hours post birth and 3-5 months: infant haemoglobin, haematocrit, MCV, transferrin saturation, ferritin, and (at 24 hours post birth only) serum bilirubin. At 3-5 months $M C V<73 \mathrm{fL}$, serum transferrin < $20 \mu \mathrm{g} / \mathrm{L}$, transferring saturation $<10 \%$ and anaemia (haemoglobin $<10.5 \mathrm{~g} / \mathrm{dL}$ ).

Notes

\section{Risk of bias}

\begin{tabular}{lll}
\hline Bias & Authors' judgement & Support for judgement \\
\hline $\begin{array}{l}\text { Random sequence genera- } \\
\text { tion (selection bias) }\end{array}$ & Unclear risk & Not described. \\
\hline $\begin{array}{l}\text { Allocation concealment } \\
\text { (selection bias) }\end{array}$ & Unclear risk & $\begin{array}{l}\text { It was reported that the attending midwife opened a sealed envelope show- } \\
\text { ing treatment allocation } 20 \text { minutes before the birth (it was not clear that all } \\
\text { envelopes were accounted for and it appeared that there may have been post } \\
\text { randomisation exclusions). }\end{array}$ \\
\hline
\end{tabular}

\begin{tabular}{|c|c|c|}
\hline $\begin{array}{l}\text { Blinding (performance } \\
\text { bias and detection bias) } \\
\text { All outcomes }\end{array}$ & Unclear risk & $\begin{array}{l}\text { Blinding women and staff not feasible although it was stated that neonatal as- } \\
\text { sessments and laboratory assessments were carried out by staff blind to ran- } \\
\text { domisation group. }\end{array}$ \\
\hline
\end{tabular}

\begin{tabular}{ll}
\hline $\begin{array}{l}\text { Incomplete outcome data } \\
\text { (attrition bias) }\end{array}$ & High risk \\
$\begin{array}{ll}\text { All outcomes } & \text { It was stated that } 180 \text { women were randomised and that data at 3-5 months } \\
& \text { were available for } 160 \text {. The analysis does not appear to have been on an ITT } \\
& \text { basis. It was stated that randomisation occurred } 20 \text { minutes before delivery, } \\
\text { however it seems likely that there were post randomisation exclusions as sev- } \\
\text { eral exclusion criteria would be apparent at the birth (e.g. } 18 \text { infants requiring } \\
\text { resuscitation were excluded). }\end{array}$
\end{tabular}

\begin{tabular}{lll}
\hline $\begin{array}{l}\text { Selective reporting (re- } \\
\text { porting bias) }\end{array}$ & Unclear risk & Assessment from published study report. \\
\hline Other bias & Low risk & Groups appeared comparable at baseline. \\
\hline
\end{tabular}

\section{Andersson 2011}

\begin{tabular}{|c|c|}
\hline Methods & Randomised controlled trial: NCT01245296. \\
\hline \multirow[t]{5}{*}{ Participants } & 400 women in Sweden. Normal birth at term. \\
\hline & Setting: Hospital in Halmstad, Sweden. Study conducted between April 2008 and September 2009. \\
\hline & Inclusion criteria: \\
\hline & $\begin{array}{l}\text { Non-smoking, healthy women after normal pregnancy, singleton, term pregnancy, expected vaginal } \\
\text { birth with cephalic presentation. Swedish speaking and living close enough to study hospital to attend } \\
\text { for follow-up. }\end{array}$ \\
\hline & $\begin{array}{l}\text { Exclusion criteria:serious congenital malformations, syndromes or other congenital diseases that could } \\
\text { affect the outcome measures. }\end{array}$ \\
\hline \multirow[t]{2}{*}{ Interventions } & $\begin{array}{l}\text { Early umbilical cord clamping (at or before } 10 \text { secs) versus delayed cord clamping (> } 180 \text { secs ( } 3 \text { min- } \\
\text { utes)). }\end{array}$ \\
\hline & $\begin{array}{l}\text { In both groups the midwife was instructed to hold the baby } 20 \mathrm{~cm} \text { below the vulva for } 30 \text { secs and then } \\
\text { place the baby on the mother's abdomen. Oxytocin (10 IU) IV was administered immediately after } \\
\text { clamping. The time to clamping was measured using a stopwatch. }\end{array}$ \\
\hline
\end{tabular}


Andersson 2011 (Continued)

Early clamping was the standard procedure before the study.

Outcomes Postpartum haemorrhage; length of third stage of labour; maternal blood transfusion; umbilical arterial and venous blood gases; jaundice; iron stores in infants at 2-3 days of age and 4 months post birth, polycythaemia; neurodevelopment at 4 months (assessed by ASQ), immunoglobulin G at birth, 2-3 days, and 4 months, symptoms of infection during first 4 months.

Notes

\section{Risk of bias}

\begin{tabular}{|c|c|c|}
\hline Bias & Authors' judgement & Support for judgement \\
\hline $\begin{array}{l}\text { Random sequence genera- } \\
\text { tion (selection bias) }\end{array}$ & Low risk & Computer randomisation in blocks (random number generator in MS Excel). \\
\hline $\begin{array}{l}\text { Allocation concealment } \\
\text { (selection bias) }\end{array}$ & Low risk & $\begin{array}{l}\text { "When delivery was imminent (expected within } 10 \text { minutes), the midwife } \\
\text { opened a sealed, numbered, opaque envelope containing the treatment allo- } \\
\text { cation)." }\end{array}$ \\
\hline $\begin{array}{l}\text { Blinding (performance } \\
\text { bias and detection bias) } \\
\text { All outcomes }\end{array}$ & Unclear risk & $\begin{array}{l}\text { Mother and midwife were not blinded. Doctors carrying out neonatal examina- } \\
\text { tions and laboratory staff performing analyses were blind to group allocation. }\end{array}$ \\
\hline $\begin{array}{l}\text { Incomplete outcome data } \\
\text { (attrition bias) } \\
\text { All outcomes }\end{array}$ & Unclear risk & $\begin{array}{l}\text { There were a small number of post-randomisation exclusions (18/400) how- } \\
\text { ever, for many outcomes there were missing data. For primary outcomes } \\
\text { (haemoglobin and iron status at } 4 \text { months } 347 / 400 \text { were followed up ( } 87 \%) \text {; } \\
\text { loss to follow-up was similar in the two arms of the trial; neurodevelopmental } \\
\text { outcomes were measured in a subset of infants at } 4 \text { months ( } 180 \text { in the early } \\
\text { clamping group and } 185 \text { in the late clamping group). }\end{array}$ \\
\hline $\begin{array}{l}\text { Selective reporting (re- } \\
\text { porting bias) }\end{array}$ & Unclear risk & Unable to assess (assessment from published study report only). \\
\hline Other bias & Unclear risk & $\begin{array}{l}\text { Group characteristics appeared similar at baseline. It was stated that routine } \\
\text { care was early clamping. }\end{array}$ \\
\hline
\end{tabular}

\section{Cernadas 2006}

\begin{tabular}{ll}
\hline Methods & Randomised controlled trial. \\
\hline Participants & Women who had an uneventful cephalic vaginal or caesarean section birth, and singleton pregnancy at \\
term; consented at 36 weeks' gestation visit. & 276 women randomised. \\
& 2 obstetrical units in Argentina. \\
& Exclusion criteria included diabetes, pre-eclampsia, hypertension, evidence of IUGR (estimated weight \\
& $<10$ th percentile), congenital malformation. \\
& 3 interventions were compared. \\
& 1. Early umbilical cord clamping (within 1 st 15 secs of birth). \\
$\mathrm{n}=93$ [88/93 received the intervention - no cause given for 5 changes]. \\
2. Cord clamping at 1 minute after birth \\
$\mathrm{n}=91$ [83/91 received the intervention - 8 changes ( 2 no breathing in the first 10 secs; 1 tight nuchal \\
cord; 2 with both no breathing in first 10 secs and tight nuchal cord; 1 other cause; 2 no cause)]. \\
3. Cord clamping at 3 minutes after birth.
\end{tabular}


$\mathrm{n}=92$ [83/92 received the intervention -9 changes ( 4 no breathing in the first 10 secs; 1 no breathing in the first 10 secs and tight nuchal cord; 1 secondary apnoea; 1 spontaneous third stage; 1 amniotic fluid stained with meconium; 1 no cause)].

The latter 2 timing interventions were considered to be delayed.

In vaginal births, if the cord clamping allocation was delayed, the infant was placed in the mother's arm while awaiting cord clamping. If a caesarean birth, the infant was placed on the mother's lap and swaddled to prevent heat loss while awaiting cord clamping.

States no additional interventions were performed - interpret as no oxytocics?

Maternal outcomes: postpartum blood loss volume and maternal haematocrit at 24 hours post birth.
Infant outcomes: newborn venous haematocrit at 6 hours after birth, neonatal haematocrit and plas-
ma bilirubin levels at 24 and 48 hours of age, early neonatal mortality and morbidity (tachypnoea, res-
piratory grunting, respiratory distress, jaundice, seizures, sepsis, necrotising enterocolitis), admis-
sion to NICU, newborn length of hospital stay, any neonatal disease that occurred between birth and 1
month, weight and method of feeding at 1 month.

Notes

\title{
Risk of bias
}

\begin{tabular}{lll}
\hline Bias & Authors' judgement & Support for judgement \\
\hline $\begin{array}{l}\text { Random sequence genera- } \\
\text { tion (selection bias) }\end{array}$ & Low risk & $\begin{array}{l}\text { Computer-generated random numbers - stratified by hospital and then by } \\
\text { mode of birth within each hospital. Variable length blocks were used. }\end{array}$ \\
\hline $\begin{array}{l}\text { Allocation concealment } \\
\text { (selection bias) }\end{array}$ & Low risk & $\begin{array}{l}\text { Allocation by sealed opaque sequentially numbered envelopes - the allocation } \\
\text { was read out to the attending clinician.Staff responsible for random genera- } \\
\text { tion and allocation concealment processes were not involved in the recruit- } \\
\text { ment phase of the trial. }\end{array}$
\end{tabular}

Blinding (performance Unclear risk

bias and detection bias)

Paediatricians assessing the outcomes were unaware of the assigned interven-

All outcomes

tions.

Nature of the intervention meant that others could not be blinded.

\begin{tabular}{|c|c|}
\hline $\begin{array}{l}\text { Incomplete outcome data } \\
\text { (attrition bias) }\end{array}$ & Low risk \\
\hline
\end{tabular}

All outcomes early 3/93; late 1 minute 1/91; late 3 minutes $0 / 92$.

Selective reporting (re- Unclear risk $\quad$ Assessment from published study report only. porting bias)

Other bias Unclear risk

\begin{abstract}
More than a quarter of the women included had caesarean births. This may mean data from this study are affected by neonatal clinicians attending the delivery. In the past, babies delivered by caesarean were routinely admitted to special, or neonatal intensive care. In this study the number of caesarean births was balanced in the intervention and control groups so the impact of including data for these women is not clear.
\end{abstract}

\section{Chaparro 2006}

Methods Randomised controlled trial.


Women at term (equal to or greater than 36 weeks' and less than 42 weeks' gestation, where a vaginal birth of a healthy singleton infant was anticipated, the woman planned to breastfeed for at least 6 months, was a non-smoker, was able to return for follow-up visits and there were no complicating medical or obstetric factors.

Exclusion criteria applied after birth were low birthweight $(<2500 \mathrm{~g})$ and major congenital malformations.

Setting: large obstetrics hospital in Mexico City, Mexico.

$\begin{array}{ll}\text { Interventions } & \text { Early clamping (10 secs after birth) }(n=239) ; \\ \text { late clamping ( } 2 \text { minutes after birth) }(n=237) . \\ \text { Any condition arising that necessitated earlier clamping was adhered to. }\end{array}$

\begin{tabular}{ll}
\hline Outcomes & Maternal: estimated maternal blood loss at birth. \\
Infant: haematological and iron status at 6 months of age, newborn haematocrit and reported neona- \\
tal jaundice between birth and 14 days of age, exclusive breastfeeding.
\end{tabular}

Notes Jaundice was self-report by mother, and so was not entered under the outcome of clinical jaundice.

\section{Risk of bias}

\begin{tabular}{lll}
\hline Bias & Authors' judgement & Support for judgement \\
\hline $\begin{array}{l}\text { Random sequence genera- } \\
\text { tion (selection bias) }\end{array}$ & Low risk & Blocks of 4 generated by random digital generator in Microsoft Excel. \\
\hline $\begin{array}{l}\text { Allocation concealment } \\
\text { (selection bias) }\end{array}$ & Low risk & $\begin{array}{l}\text { Numbered index cards with allocation were sealed in numbered opaque en- } \\
\text { velopes ordered sequentially. }\end{array}$ \\
\hline $\begin{array}{l}\text { Blinding (performance } \\
\text { bias and detection bias) }\end{array}$ & Unclear risk & No mention of blinding. \\
\hline $\begin{array}{l}\text { All outcomes } \\
\text { Incomplete outcome data } \\
\text { All outcomes }\end{array}$ & Unclear risk & $\begin{array}{l}\text { Losses to follow-up: early group: } 68 / 239 \text { lost to follow-up at } 6 \text { months (27 no } \\
\text { longer interested, } 7 \text { moved away, } 28 \text { could not be located, } 5 \text { lack of time, } 1 \text { in- } \\
\text { fant ill); } \\
\text { leaving } 171 \text { who completed the study at } 6 \text { months. There were also } 2 \text { protocol } \\
\text { violations (cord clamping more than } 30 \text { secs after the delivery of the infant's } \\
\text { shoulders), } 1 \text { nuchal cord, } 1 \text { reason not recorded. } \\
157 \text { had full blood sample analysis. } \\
\text { Late group: } 50 / 237 \text { lost to follow-up at } 6 \text { months (25 no longer interested, } 4 \\
\text { moved away, } 16 \text { could not be located, } 3 \text { lack of time, } 1 \text { infant died, } 1 \text { participa- } \\
\text { tion in other study), leaving } 187 \text { who completed the study at } 6 \text { months. There } \\
\text { were also } 52 \text { protocol violations (clamping at less than } 100 \text { secs after delivery } \\
\text { of infant's shoulders), } 30 \text { concerns for infant's condition, } 15 \text { forceps used, } 3 \text { in- } \\
\text { fants born in labour room bed, } 4 \text { misunderstanding of treatment group. } \\
171 \text { had full blood analysis. }\end{array}$ \\
\hline
\end{tabular}

Selective reporting (re- $\quad$ Unclear risk $\quad$ Assessment from published study report only.
porting bias)
porting bias)

Other bias Low risk Other risk of bias not apparent.


Emhamed 2004

\begin{tabular}{ll}
\hline Methods & Randomised controlled trial. \\
\hline Participants & $112(104)$ women in a large Libyan hospital who consented during first stage of labour. \\
& Exclusion criteria: women with known medical or obstetric problems, less than 37 weeks' or greater \\
than 42 weeks' gestation. & Post randomisation exclusions were an infant weighing less than $2500 \mathrm{~g}$, instrumental births, respira- \\
tory distress, congenital abnormalities or the need for early cord clamping.
\end{tabular}

Interventions $\quad$ Early (immediate) cord clamping (10 secs following birth $(n=46)$;

late cord clamping (when cord pulsation ceased) $(n=58)$.

Oxytocin given when cord clamping had been performed.

Outcomes Maternal: pre and post birth haemoglobin and haematocrit.

Infant: haemoglobin and haematocrit (including cord blood), polycythaemia, hyperviscosity and jaun-

dice.

\section{Notes}

\section{Risk of bias}

\begin{tabular}{|c|c|c|}
\hline Bias & Authors' judgement & Support for judgement \\
\hline $\begin{array}{l}\text { Random sequence genera- } \\
\text { tion (selection bias) }\end{array}$ & Unclear risk & Not described. \\
\hline $\begin{array}{l}\text { Allocation concealment } \\
\text { (selection bias) }\end{array}$ & Low risk & Consecutive allocation of opaque envelopes. \\
\hline $\begin{array}{l}\text { Blinding (performance } \\
\text { bias and detection bias) } \\
\text { All outcomes }\end{array}$ & Unclear risk & Not stated. \\
\hline $\begin{array}{l}\text { Incomplete outcome data } \\
\text { (attrition bias) } \\
\text { All outcomes }\end{array}$ & Low risk & $\begin{array}{l}\text { Losses to follow-up: } 1 \text { mother/baby pair from each group ( } 1 / 58 \text { late; } 1 / 46 \text { ear- } \\
\text { ly) left hospital before reassessment and so were not available for those out- } \\
\text { comes measured } 16-24 \text { hours after birth. } \\
4 / 50 \text { pairs from the early group and } 4 / 62 \text { from the late group were excluded af- } \\
\text { ter randomisation because of intrapartum asphyxia. }\end{array}$ \\
\hline $\begin{array}{l}\text { Selective reporting (re- } \\
\text { porting bias) }\end{array}$ & Unclear risk & Assessment from published study report only. \\
\hline Other bias & Low risk & Other risk of bias not apparent. \\
\hline
\end{tabular}

\section{Geethanath 1997}

\begin{tabular}{ll}
\hline Methods & Randomised controlled trial. \\
\hline Participants & $\begin{array}{l}107 \text { women (anticipating a term vaginal birth and not experiencing any medical or obstetric complica- } \\
\text { tions including anaemia of }<10 \mathrm{~g} / \mathrm{dL}) . \\
\text { New Delhi hospital, India. } \\
\text { Post randomisation exclusions were applied in the presence of birth asphyxia, major congenital malfor- } \\
\text { mations. }\end{array}$
\end{tabular}


Geethanath 1997 (Continued)

Interventions

Early cord clamping: cord clamped as soon as the infant was born;

Late clamping: cord clamped after the placenta had descended into the vagina during which time the infant was held $10 \mathrm{~cm}$ below the vaginal introitus.

Outcomes Maternal: haemoglobin shortly after giving birth.

Infant: cord blood at birth and venous blood sample at 3 months for ferritin and haemoglobin estimation.

\section{Notes}

\section{Risk of bias}

\begin{tabular}{lll}
\hline Bias & Authors' judgement & Support for judgement \\
\hline $\begin{array}{l}\text { Random sequence genera- } \\
\text { tion (selection bias) }\end{array}$ & Low risk & Computer-generated random number sequences. \\
\hline $\begin{array}{l}\text { Allocation concealment } \\
\text { (selection bias) }\end{array}$ & Low risk & Allocation by opaque, sealed envelopes. \\
\hline $\begin{array}{l}\text { Blinding (performance } \\
\text { bias and detection bias) } \\
\text { All outcomes }\end{array}$ & Unclear risk & Not reported. \\
\hline $\begin{array}{l}\text { Incomplete outcome data } \\
\text { (attrition bias) } \\
\text { All outcomes }\end{array}$ & Low risk & Post randomisation exclusions were reported (presence of birth asphyxia, ma- \\
\hline $\begin{array}{l}\text { Selective reporting (re- } \\
\text { porting bias) }\end{array}$ & Unclear risk & jor congenital malformations) but no losses to follow-up are reported. \\
\hline \begin{tabular}{l} 
Other bias \\
\hline
\end{tabular} & Low risk & Not clear from paper. \\
\hline
\end{tabular}

Gupta 2002

\begin{tabular}{|c|c|}
\hline Methods & Randomisd controlled trial. \\
\hline \multirow[t]{3}{*}{ Participants } & $\begin{array}{l}102 \text { infant-mother pairs - hospital born neonates born vaginally to pregnant women with anaemia } \\
\text { (haemoglobin }<100 \mathrm{~g} / \mathrm{L} \text { at term) }\end{array}$ \\
\hline & $\begin{array}{l}\text { Exclusion criteria: medical or pregnancy related complications e.g. eclampsia, severe heart failure, se- } \\
\text { vere antepartum haemorrhage or } \mathrm{rH} \text { iso-immunisation. } \\
\text { Post randomisation exclusions: Infants who needed resuscitation at birth or who had major congenital } \\
\text { malformations. }\end{array}$ \\
\hline & Teaching hospital, New Delhi. \\
\hline
\end{tabular}

Interventions

Early cord clamping group (cord clamped immediately after the birth of the infant), $n=53$.

Late cord clamping (cord clamped after the placenta had descended into the vagina), $n=49$ - during this time the infant was warmly wrapped and held below the level of the mothers abdomen but within $10 \mathrm{~cm}$ of the vagina.

$4 \mathrm{~mL}$ of maternal venous blood was taken at the time of the birth, $4 \mathrm{~mL}$ of cord blood at birth and $4 \mathrm{~mL}$ venous blood from the infant at 3 months of age.

Infants were not given any medicinal iron supplementation during the study period. 
Gupta 2002 (Continued)

Outcomes

Maternal: haemoglobin at birth.

Infant: haemoglobin at 3 months, weight gain, feeding patterns, respiratory infections and diarrhoea.

Notes

Risk of bias

\begin{tabular}{lll}
\hline Bias & Authors' judgement & Support for judgement \\
\hline $\begin{array}{l}\text { Random sequence genera- } \\
\text { tion (selection bias) }\end{array}$ & Low risk & Computer-generated random number sequences. \\
\hline $\begin{array}{l}\text { Allocation concealment } \\
\text { (selection bias) }\end{array}$ & Low risk & Allocation concealed by opaque sealed envelopes. \\
\hline $\begin{array}{l}\text { Blinding (performance } \\
\text { bias and detection bias) } \\
\text { All outcomes }\end{array}$ & Unclear risk & Not stated. \\
\hline $\begin{array}{l}\text { Incomplete outcome data } \\
\text { (attrition bias) }\end{array}$ & High risk & $\begin{array}{l}\text { Post randomisation exclusions: Infants who needed resuscitation at birth or } \\
\text { who had major congenital malformations. }\end{array}$ \\
\hline $\begin{array}{l}\text { Sellective reporting (re- } \\
\text { porting bias) }\end{array}$ & Unclear risk & $\begin{array}{l}\text { Losses to follow-up: at 3 months, 58 (57\%) of the original 102 mother-infant } \\
\text { pairs were available, 29 pairs in each group. }\end{array}$ \\
\hline $\begin{array}{l}\text { Other bias } \\
\text { bias is difficult to assess. }\end{array}$ \\
\hline
\end{tabular}

Jahazi 2008

Methods Described as double-blind randomised controlled trial. A total of 64 women were allocated to either
the early or delayed umbilical cord clamping arms via toss of a coin.

Participants Women with uncomplicated pregnancies, between 38 and 42 weeks gestation and anticipating a normal vaginal birth were deemed eligible for participation

Interventions Immediately prior to birth women were randomised to receive either early cord clamping ( 30 secs) $n=$ 30 women or delayed cord clamping ( 3 minutes) $n=34$ women. Timing was observed by a midwife using a stopwatch from the time of complete birth of the baby. The infant was held supine at the level of the introitus. In the delayed cord clamping group the infant was placed on a table at the level of the introitus and wiped dry with a warm sterile towel. $1 \mathrm{~mL}$ of cord blood was collected immediately following cord clamping and $1 \mathrm{~mL}$ antecubital blood was collected from the infant at 2 hours and 18 hours post birth.

All women in the study received IM oxytocin (10 IU) following cord ligation. All infants were breastfed

Outcomes

Maternal: duration of the third stage of labour.

Infant outcomes reported were: gestational age, birthweight, Apgars at 1 and 5 minutes, placental residual blood volume (PRCV)and estimated neonatal blood volume at birth (ENBV), haematocrit values at birth, 2 and 18 hours post birth. 

time points listed for blood collection and at 5 days post birth but outcomes of those observations are not reported. trial was double blinded) but description in the paper would indicate that this is inaccurate. Also, asked if the polycythaemia data were available in a table format to enable the figures and comparisons of the individual components to be more accurately reported.

\section{Risk of bias}

\begin{tabular}{|c|c|c|}
\hline Bias & Authors' judgement & Support for judgement \\
\hline $\begin{array}{l}\text { Random sequence genera- } \\
\text { tion (selection bias) }\end{array}$ & Low risk & Toss of coin to determine randomisation to one of two groups. \\
\hline $\begin{array}{l}\text { Allocation concealment } \\
\text { (selection bias) }\end{array}$ & Unclear risk & Further information requested from authors. \\
\hline $\begin{array}{l}\text { Blinding (performance } \\
\text { bias and detection bias) } \\
\text { All outcomes }\end{array}$ & Unclear risk & $\begin{array}{l}\text { The authors have stated the study was double blinded but the description is } \\
\text { not that of a blinded trial. Further information has been sought from the au- } \\
\text { thors. }\end{array}$ \\
\hline $\begin{array}{l}\text { Incomplete outcome data } \\
\text { (attrition bias) } \\
\text { All outcomes }\end{array}$ & Unclear risk & $\begin{array}{l}\text { More information has been requested from the authors related to the data for } \\
\text { polycythaemia. }\end{array}$ \\
\hline $\begin{array}{l}\text { Selective reporting (re- } \\
\text { porting bias) }\end{array}$ & Unclear risk & $\begin{array}{l}\text { Infants with Apgars less than } 7 \text { at } 1 \text { or } 5 \text { minutes were excluded from analysis, } \\
\text { Infants who were small ( }<10 \text { th percentile) or large ( }>90 \text { th percentile) for gesta- } \\
\text { tional age were excluded as were infants with a cord blood haematocrit of }<40 \\
\text { or }>65 \text { and infants with congenital abnormalities. }\end{array}$ \\
\hline Other bias & Unclear risk & Not able to assess from data provided. \\
\hline
\end{tabular}

\section{McDonald 1996}

Methods Randomised controlled trial.

Participants All women attending the antenatal clinic at King Edward Memorial Hospital, Western Australia randomised when a vaginal birth was thought to be imminent.

Exclusions: maternal refusal to participate in the study; caesarean section; breech delivery; multiple pregnancy; fetal indication (e.g., known fetal anomaly); preterm birth (<37 completed weeks' gestation).

1000 women were randomised to the trial; the data of 37 women were excluded due to insufficient information available to include in the analyses, leaving data for 963 women available for analysis. tonic administration $(n=244)$; late cord clamping and late uterotonic administration $(n=239)$.

Definitions: early cord clamping involved clamping immediately following birth of the body of the baby; late cord clamping occurred when cord pulsation had ceased or at 5 minutes if cord pulsation had not already ceased. This time limit was imposed to reduce the risk of compromising infants who may have any undiagnosed underlying conditions such as a PDA; early uterotonic administration involved administration at the time of birth of the anterior shoulder of the baby; late uterotonic administration 
McDonald 1996 (Continued)

was after the birth of the baby (literally) and if the cord clamping allocation was early, then it was allocated to be after the cord was clamped (i.e. not within 30 secs).

Outcomes

Maternal: PPH = or $>500 \mathrm{~mL}$, = or $>1000 \mathrm{~mL}$; mean blood loss; need for blood transfusion; need for manual removal of placenta; length of third stage ( $>30$ minutes and $>60$ minutes); need for therapeutic uterotonics; evacuation of retained products; inversion of the uterus; length of hospital stay. Neonatal: Apgar score < 6 at 5 minutes; admission to NICU; jaundice requiring phototherapy (> 1 day); need for serum bilirubin test; breastfeeding at discharge.

\section{Notes}

Sample size: the initial sample size calculation was based on an anticipation that the PPH rate from a uterotonic choice trial (McDonald 1996) would be around 10\%. It was calculated that a sample size of 3000 women would be required to have an $80 \%$ chance of detecting a $50 \%$ reduction in $\mathrm{PPH}$ at the $5 \%$ level of statistical significance. However, review during the trial by a Data Monitoring Committee determined that the PPH rate was greater than the $10 \%$ rate predicted, the actual recorded PPH rate being around $16 \%$; this reduced the required sample size to 1,100 women.

Blood loss assessment: "the major endpoint of the study was PPH ascertained by measurement of collected blood spillage where possible and all other blood loss estimated by visual estimation. The trial could not be 'blind' at this point; the clinician carrying out the intervention was also attempting to assess the blood loss. The authors attempted to obtain objective indices of blood loss in the form of 1. postpartum haemoglobin, 2. calculation of the difference between antepartum and postpartum haemoglobin. Although these measures may not be reliable measures of the amount of blood loss by an individual, they are objective, independent of observer bias and were carried out on women in the trial without knowledge of which intervention was used".

Jaundice assessment: Clinicians assessing jaundice are not likely to have been aware of the allocation to early and late clamping groups.

The study was written up as a PhD thesis, a copy of which is available from the Pregnancy and Childbirth Group office. It has never been submitted for journal publication.

\section{Risk of bias}

\begin{tabular}{lll}
\hline Bias & Authors' judgement & Support for judgement \\
\hline $\begin{array}{l}\text { Random sequence genera- } \\
\text { tion (selection bias) }\end{array}$ & Low risk & List of computer-generated random numbers. \\
\hline $\begin{array}{l}\text { Allocation concealment } \\
\text { (selection bias) }\end{array}$ & Low risk & $\begin{array}{l}\text { Opaque, sealed, sequentially numbered envelopes kept at a central location in } \\
\text { the delivery ward. }\end{array}$ \\
\hline $\begin{array}{l}\text { Blinding (performance } \\
\text { bias and detection bias) } \\
\text { All outcomes }\end{array}$ & Unclear risk & $\begin{array}{l}\text { The trial could not be 'blind' as the clinician carrying out the intervention was } \\
\text { also attempting to assess the blood loss. The authors attempted to obtain ob- } \\
\text { jective indices of blood loss in the form of 1. postpartum haemoglobin, } 2 . \text { cal- } \\
\text { culation of the difference between antepartum and postpartum haemoglo- } \\
\text { bin. Although these measures may not be reliable measures of the amount of } \\
\text { blood loss by an individual, they are objective, independent of observer bias } \\
\text { and were carried out on women in the trial without knowledge of which inter- } \\
\text { vention was used". }\end{array}$ \\
\hline
\end{tabular}

\begin{tabular}{|c|c|c|}
\hline $\begin{array}{l}\text { Incomplete outcome data } \\
\text { (attrition bias) } \\
\text { All outcomes }\end{array}$ & Low risk & $\begin{array}{l}\text { Losses to follow-up: all women allocated to receive a particular timing op- } \\
\text { tion were included in the intended group with the exception of } 37 \text { women for } \\
\text { whom no trial number was recorded ( } 14 / 250 \text { in early cord clamping and ear- } \\
\text { ly uterotonic group; } 6 / 250 \text { in late cord clamping and early uterotonic group; } \\
6 / 250 \text { in early cord clamping and late uterotonic; and } 11 / 250 \text { in late cord } \\
\text { clamping and late uterotonic group). }\end{array}$ \\
\hline
\end{tabular}

$\begin{aligned} & \text { Selective reporting (re- Low risk } \quad \text { Further information on outcomes was available from the author. } \\ & \text { porting bias) }\end{aligned}$


McDonald 1996 (Continued)

Other bias Low risk Not apparent.

Nelson 1980

Methods Randomised controlled trial. Randomisation: "assigned randomly" - no further details provided.

Participants Women considered to be at low obstetrical risk, interested in the Leboyer approach to birth, and intending to attend psychoprophylactic prenatal classes.

Exclusion criteria: giving birth before 36 weeks, not available for 3 day and 8 month assessments.

Interventions

Early ('conventional') birth with cord clamping within 1 minute of birth $(n=26)$; median time of 45 secs.

Late (Leboyer method with cord clamped when it stopped pulsating); $\mathrm{n}=28$; median time of 180 secs.

Outcomes

Maternal: length of first, second and third stages of labour, mother's experience of labour and birth, maternal psychological adjustment at 6 weeks, maternal perception of infant behaviour at 3 days, 6 weeks and 8 months postpartum (Carey Scales of Infant Temperament), PPH (blood loss threshold not defined), extension of episiotomy, infected episiotomy, endometritis, urinary tract infection.

Infant: perinatal asphyxia, hypothermia (one or more axillary temp $>35 \mathrm{C}$ ), respiratory rate more than

60 , polycythaemia (24-hour capillary haemoglobin more than $25 \mathrm{~g}$ per $100 \mathrm{~mL}$ [more than $15.51 \mathrm{mmol}$ /

L]), jaundice, hyperbilirubinaemia (serum bilirubin more than $12 \mathrm{mg}$ per $100 \mathrm{~mL}$ [more than 205.2 umol/L]).

\section{Notes}

\section{Risk of bias}

\begin{tabular}{lll}
\hline Bias & Authors' judgement & Support for judgement \\
\hline $\begin{array}{l}\text { Random sequence genera- } \\
\text { tion (selection bias) }\end{array}$ & Unclear risk & "assigned randomly" - no further details provided. \\
\hline $\begin{array}{l}\text { Allocation concealment } \\
\text { (selection bias) }\end{array}$ & Unclear risk & No details provided. \\
\hline $\begin{array}{l}\text { Blinding (performance } \\
\text { bias and detection bias) } \\
\text { All outcomes }\end{array}$ & Unclear risk & $\begin{array}{l}\text { Women and care providers would be aware of allocation. 2nd observer blinded } \\
\text { for Brazelton Neonatal Behavioural Assessment Scale, infant Bayley Scales of } \\
\text { Infant Development assessed blind. }\end{array}$ \\
\hline $\begin{array}{l}\text { Incomplete outcome data } \\
\text { (attrition bias) } \\
\text { All outcomes }\end{array}$ & Low risk & $\begin{array}{l}\text { Losses to follow-up: 1/55 (dropped out from conventional (early clamping) } \\
\text { group. }\end{array}$ \\
\hline $\begin{array}{l}\text { Selective reporting (re- } \\
\text { porting bias) }\end{array}$ & Unclear risk & Assessment from published study report only. \\
\hline \begin{tabular}{l} 
Other bias \\
\hline
\end{tabular} & Low risk & Not apparent. \\
\hline
\end{tabular}

Oxford Midwives 1991

\begin{tabular}{ll}
\hline Methods & Randomised controlled trial. \\
\hline Participants & 554 women.
\end{tabular}


Oxford Midwives 1991 (Continued)

Setting: large teaching hospital in Oxford, UK.

\begin{tabular}{ll} 
Interventions & Early clamping (as soon as possible after the birth) or late clamping (3 minutes after the birth). \\
\hline Outcomes & Maternal: PPH, manual removal of placenta. \\
Neonatal: respiratory problems e.g. transient tachypnoea, grunting, rib recession, heart or cardiovas- \\
cular problems, clinical jaundice (whether jaundice had been noted, the duration and level of jaun- \\
dice as indicated by serum bilirubin if blood samples were taken, whether treated with phototherapy), \\
birthweight, feeding method, duration of cord adherence.
\end{tabular}

Notes

Data from 100 women recruited to pilot the trial design was subsequently included in the total of 554 women. It is not clear whether the pilot data was unblinded and therefore may have biased the larger trial.

\section{Risk of bias}

\begin{tabular}{lll}
\hline Bias & Authors' judgement & Support for judgement \\
\hline $\begin{array}{l}\text { Random sequence genera- } \\
\text { tion (selection bias) }\end{array}$ & Low risk & Generation by random-number tables (simple unblocked and unstratified). \\
\hline $\begin{array}{l}\text { Allocation concealment } \\
\text { (selection bias) }\end{array}$ & Low risk & $\begin{array}{l}\text { Sealed opaque envelopes were consecutively numbered and centrally stored } \\
\text { in the delivery suite. }\end{array}$
\end{tabular}

\section{Blinding (performance Unclear risk}

bias and detection bias)

All outcomes

Incomplete outcome data Low risk

(attrition bias)

All outcomes

\begin{abstract}
Women would be aware of allocation. None of the midwives involved in the postnatal care of women participating in the trial was aware of the original trial allocation.
\end{abstract}

Protocol deviations: It is reported that 264/296 infants in the late cord clamping group received the actual management allocated and 252/256 received the actual management allocation. 32 deviations (19 cord around neck, 9 asphyxia,1 maternal emergency and 3 others) were reported. All protocol deviation data were included in the groups to which they were originally allocated for the purpose of analysis (ITT).

Loss to follow-up not reported.

Selective reporting (re- Unclear risk Assessment from published study report.
porting bias)

$\begin{array}{ll}\text { Other bias } & \text { Unclear risk } \\ & \begin{array}{l}\text { Data from } 100 \text { women recruited to pilot the trial design was subsequently in- } \\ \text { cluded in the total of } 554 \text { women. It is not clear whether the pilot data was un- } \\ \text { blinded and therefore may have biased the larger trial. }\end{array}\end{array}$

Philip 1973

\begin{tabular}{ll}
\hline Methods & Randomised controlled trial, 2-arm trial with individual randomisation. \\
\hline Participants & Setting: 57 women attending an Edinburgh (Scotland, UK) over a 6 month period in 1969. \\
& Inclusion criteria: Women with uncomplicated pregnancy and term infants with no evidence of blood \\
& group incompatibility. \\
& Exclusion criteria: Not stated.
\end{tabular}

Interventions

Early clamping: immediately after the delivery of the baby's buttocks (usually achieved within 5 secs and never longer than 15 secs). $\mathrm{N}=28$. 
Philip 1973 (Continued)

Delayed clamping: more than 10 secs after the doctor or midwife thought that the baby was breathing well (mean time 94 secs after birth). $\mathrm{N}=29$.

In both groups the baby was placed approximately $15 \mathrm{~cm}$ below the perineum.

Outcomes

Apgar score at 5 minutes, birthweight, cord blood hematocrit, bilirubin, haptoglobin, reticulocyte count and infant blood at 24 and 72 hours.

Notes

For continuous outcomes mean and SE were reported. We calculated the SD.

\section{Risk of bias}

\begin{tabular}{|c|c|c|}
\hline Bias & Authors' judgement & Support for judgement \\
\hline $\begin{array}{l}\text { Random sequence genera- } \\
\text { tion (selection bias) }\end{array}$ & Unclear risk & $\begin{array}{l}\text { Not described. "Infants were randomly selected for one of two methods of } \\
\text { cord clamping". }\end{array}$ \\
\hline $\begin{array}{l}\text { Allocation concealment } \\
\text { (selection bias) }\end{array}$ & Unclear risk & $\begin{array}{l}\text { Not described. "Infants were randomly selected for one of two methods of } \\
\text { cord clamping". }\end{array}$ \\
\hline $\begin{array}{l}\text { Blinding (performance } \\
\text { bias and detection bias) } \\
\text { All outcomes }\end{array}$ & Unclear risk & Not mentioned. \\
\hline $\begin{array}{l}\text { Incomplete outcome data } \\
\text { (attrition bias) } \\
\text { All outcomes }\end{array}$ & Unclear risk & $\begin{array}{l}\text { It was not clear that all women randomised were accounted for. There } \\
\text { were missing data for some outcomes and this was not balanced across } \\
\text { groups. }\end{array}$ \\
\hline $\begin{array}{l}\text { Selective reporting (re- } \\
\text { porting bias) }\end{array}$ & Unclear risk & Assessment from published study report only. \\
\hline Other bias & Low risk & $\begin{array}{l}\text { No other bias apparent. Very little information was provided on study meth- } \\
\text { ods. Groups appeared comparable. }\end{array}$ \\
\hline
\end{tabular}

\section{Saigal 1972}

\begin{tabular}{ll}
\hline Methods & Randomised controlled trial (no details of randomisation method). \\
\hline Participants & 45 term infants born in 2 hospitals in Montreal, Canada. \\
& Full-term infants 38 to 42 weeks' gestation, vaginal births. \\
& Exclusion criteria: infants of diabetic mothers, malformed infants, infants who developed systemic in- \\
fections, erythroblastic infants and infants who were small for date (below third percentile for gesta- \\
tional age).
\end{tabular}


Saigal 1972 (Continued)

Risk of bias

\begin{tabular}{lll}
\hline Bias & Authors' judgement & Support for judgement \\
\hline $\begin{array}{l}\text { Random sequence genera- } \\
\text { tion (selection bias) }\end{array}$ & Unclear risk & $\begin{array}{l}\text { "assigned prior to delivery according to a randomised study protocol" but no } \\
\text { further details given. }\end{array}$ \\
\hline $\begin{array}{l}\text { Allocation concealment } \\
\text { (selection bias) }\end{array}$ & Unclear risk & Not described. \\
\hline $\begin{array}{l}\text { Blinding (performance } \\
\text { bias and detection bias) } \\
\text { All outcomes }\end{array}$ & Unclear risk & Not reported. \\
\hline $\begin{array}{l}\text { Incomplete outcome data } \\
\text { (attrition bias) } \\
\text { All outcomes }\end{array}$ & Unclear risk & Losses to follow-up or deviation from protocol not reported. \\
\hline $\begin{array}{l}\text { Selective reporting (re- } \\
\text { porting bias) }\end{array}$ & Unclear risk & Assessment from published study report only. \\
\hline \begin{tabular}{l} 
Other bias \\
\hline
\end{tabular} & Unclear risk & Little information on study methods. \\
\hline
\end{tabular}

Spears 1966

\begin{tabular}{ll} 
Methods & Randomised controlled trial (no details of randomisation method). \\
\hline Participants & $\begin{array}{l}379 \text { women who gave birth vaginally to a term infant weighing greater than } 2500 \mathrm{~g} \text { at the Los Angeles } \\
\text { County General Hospital USA. }\end{array}$
\end{tabular}

Late cord clamping was defined as clamping as at 3 minutes post birth. In both instances, the infant was held level with the mother's perineum while the cord was cut $(n=187)$.

No mention of whether or when the mother received any uterotonic agent.

Outcomes Infant: Apgar scores, respiratory distress.

Notes No maternal outcomes reported that were of relevance to this review.

\section{Risk of bias}

\begin{tabular}{lll}
\hline Bias & Authors' judgement & Support for judgement \\
\hline $\begin{array}{l}\text { Random sequence genera- } \\
\text { tion (selection bias) }\end{array}$ & Unclear risk & $\begin{array}{l}\text { Randomly allocated to early or late cord clamping group upon entering the de- } \\
\text { livery room.No further information }\end{array}$ \\
\hline $\begin{array}{l}\text { Allocation concealment } \\
\text { (selection bias) }\end{array}$ & Unclear risk & No description of how the allocation process was decided. \\
\hline $\begin{array}{l}\text { Blinding (performance } \\
\text { bias and detection bias) } \\
\text { All outcomes }\end{array}$ & Unclear risk & No description of how or whether there was blinding. \\
\hline
\end{tabular}


Spears 1966 (Continued)

Incomplete outcome data Unclear risk Not reported.
(attrition bias)

All outcomes

\begin{tabular}{lll}
\hline $\begin{array}{l}\text { Selective reporting (re- } \\
\text { porting bias) }\end{array}$ & Unclear risk & $\begin{array}{l}\text { Assessment from published study report: neonatal deaths not reportedly by } \\
\text { group. }\end{array}$ \\
\hline Other bias & Unclear risk & Little information on study methods. \\
\hline
\end{tabular}

van Rheenen 2007

Methods Randomised controlled trial.

Participants

Full-term pregnant women giving birth in hospital.

105 randomised (50 to early and 55 to late cord clamping) - 45 and 46 analysed.

Exclusion criteria: before randomisation: twin pregnancy; history of PPH; gestational diabetes; preeclampsia.

After randomisation: placental separation before birth; caesarean section; tight nuchal cord necessitating early cutting; need for neonatal resuscitation; major congenital abnormalities.

Infants who weighed less than $2500 \mathrm{~g}$ or with gestational age less than 37 weeks, were excluded.

Setting: hospital in Zambia (malaria-endemic area).

Interventions

Immediate cord clamping within 20 secs of birth $(n=45)$

[mean 15 [SD 8] secs].

Cord clamped after cord stopped pulsating $(n=46)$

[mean 305 [SD 136] secs].

After vaginal birth all infants were placed between the legs of the mother (about $10 \mathrm{~cm}$ below the vaginal introitus) until the cord was clamped.

Intramuscular oxytocin was given to mothers after clamping of the cord.

Outcomes Infant: haemoglobin change from cord values; proportion of anaemic infants at 4 months after birth; duration infants remained free of anaemia (up to 6 months); adverse effects of delayed cord clamping in infants (packed cell volume changes 1 day postpartum; clinical signs of hyperviscosity syndrome or hyperbilirubinaemia) and mothers (haemoglobin change 1 day after birth, blood loss in third stage of labour); birthweight; jaundice; jaundice requiring phototherapy; ZPP levels; blood glucose; malaria; exclusive breastfeeding; infant mortality - 4 deaths (but not reported by early or late cord clamping group).

Notes

Anaemia $=$ haemoglobin concentration more than 2 SDs below the mean of similarly aged infants from an iron-supplemented USA reference population not exposed to malaria $(9.4 \mathrm{~g} / \mathrm{dL}$ at 2 months, 10.3 at 4 months and 10.5 at 6 months).

Fetal anaemia $=$ cord haemoglobin $<12.5 \mathrm{~g} / \mathrm{dL}$.

Maternal anaemia $=$ haemoglobin $<11 \mathrm{~g} / \mathrm{dL}$.

Iron deficiency = ZPP levels above $80 \mu \mathrm{mol} / \mathrm{mol}$ haem for infants and adults.

Iron-deficiency anaemia in mothers and infants = combination of ZPP above the cut-off level, together with haemoglobin more than 2 SD below the reference mean (and mean cell haemoglobin concentration below the cutoff level for 2-month follow-up).

\section{Risk of bias}


van Rheenen 2007 (Continued)

Random sequence genera- Low risk Sequentially numbered opaque sealed envelopes with unpredictable allocation (selection bias) tion code.

Allocation concealment Low risk (selection bias)

Blinding (performance

bias and detection bias)

All outcomes
Sequentially numbered opaque sealed envelopes with unpredictable allocation code.

Incomplete outcome data Unclear risk

(attrition bias)

"partially blinded" study; "one of the investigators... monitored the delivery procedure and was therefore not blinded to treatment assignment".

All outcomes

Losses to follow-up: early group: 8/45 (4 at 2 months, 2 more at 4 months, 2 more at 6 months - 6 moved, 1 died, 1 refused further participation). Late group: 11/46 ( 3 at 2 months, 4 more at 4 months, 4 more at 6 months - 6 moved, 3 died, 2 refused further participation).

Postrandomisation exclusions: 5/50 in the early group (1 low birthweight, 1 unexpected twin, 1 tight nuchal cord, 1 need for resuscitation, 1 refused further participation), 9/55 in the late group ( 2 low birthweight, 1 major congenital abnormalities, 2 unexpected twins, 3 tight nuchal cords, 1 need for resuscitation).
Selective reporting (reporting bias)
Unclear risk

Assessment from published study report only.

Other bias Low risk Not apparent.

ASQ: Ages and Stages Questionnaire

$\mathrm{fL}$ : femtolitre

IM: intramuscular

ITT: intention-to-treat

IUGR: intrauterine growth restriction

IV: intravenous

MCV: mean corpuscular volume

NICU: neonatal intensive care unit

PDA: patent ductus arteriosus

PPH: postpartum haemorrhage

$\mathrm{rH}$ : Rhesus

SD: standard deviation

SE: standard error

secs: seconds

ZPP: zinc protoporphyrin

Characteristics of excluded studies [ordered by study ID]

\begin{tabular}{ll}
\hline Study & Reason for exclusion \\
\hline Abdel Aziz 1999 & Quasi-randomised. \\
\hline Begley 1990 & $\begin{array}{l}\text { This is a comparison of active versus expectant management of the third stage of labour and so is } \\
\text { included in the Cochrane review of this topic. }\end{array}$ \\
\hline Botha 1968 & No mention of randomisation and allocation process not described. \\
\hline Buckels 1965 & No mention of randomisation and allocation process not described. \\
\hline Colozzi 1954 & No mention of randomisation and allocation process not described.
\end{tabular}




\begin{tabular}{ll}
\hline Study & Reason for exclusion \\
\hline Daily 1970 & Quasi-randomised - "every other child has early clamping and the others late clamping". \\
\hline De Paco 2011 & This was not a randomised trial, allocation to groups was alternate (quasi-randomised). \\
\hline Duckman 1953 & No mention of randomisation and allocation process not described. \\
\hline Dunn 1966 & $\begin{array}{l}\text { It was not clear that this was a randomised trial. It was stated that women were selected at random } \\
\text { and then divided into two equal groups (i.e. random selection rather than random allocation). }\end{array}$ \\
\hline Emmanouilides 1971 & No mention of randomisation and allocation process not described. \\
\hline Erickson-Owens 2012 & RCT compares early cord clamping with cord milking (not delayed cord clamping). \\
\hline Erkkola 1984 & No mention of randomisation and allocation process not described. \\
\hline Grajeda 1997 & Quasi-randomised. \\
\hline Greenberg 1967 & No mention of randomisation and allocation process not described. \\
\hline Johansen 1971 & $\begin{array}{l}\text { Quasi-randomised: control group comprised mothers born on odd dates; experimental group com- } \\
\text { prised mothers born on even dates. }\end{array}$ \\
\hline
\end{tabular}

Kemp 1971

Quasi-randomised: allocation method open to bias; "patients were allocated according to age: those whose age was an odd number became the group for abdominal manipulation, and those whose age was an even number formed the cord traction group".

Khan 1997 This is a comparison of active versus expectant management of the third stage of labour and so is
included in the Cochrane review of this topic.
included in the Cochrane review of this topic.

\begin{tabular}{ll}
\hline Kliot 1984 & No mention of randomisation and allocation process not described. \\
\hline Lanzkowsky 1960 & $\begin{array}{l}\text { This was not a randomised trial. Women in labour were admitted alternately to two different } \\
\text { labour wards. }\end{array}$ \\
\hline Linderkamp 1992 & No mention of randomisation and allocation process not described. \\
\hline Navaneethakrishnan 2010 & $\begin{array}{l}\text { This was not a trial of early verus delayed cord clamping. In this study rhesus negative women in } \\
\text { labour were randomised either to have immediate cord clamping and the cord remained clamped } \\
\text { until placental delivery versus immediate cord clamping, then the cord was cut and unclamped on } \\
\text { the maternal side to allow blood from the placenta to drain off. The purpose was to see whether } \\
\text { this reduced feto-maternal transfusion to the rhesus negative mother. Analysis was not performed } \\
\text { where the baby was also rhesus negative. }\end{array}$
\end{tabular}

\begin{tabular}{ll}
\hline Nelle 1996 & No mention of randomisation and allocation process not described. \\
\hline Newton 1961 & Quasi-randomised: allocation method by rotation. \\
\hline Prendiville 1988 & $\begin{array}{l}\text { This is a comparison of active versus expectant management of the third stage of labour and so is } \\
\text { included in the Cochrane review of this topic. }\end{array}$ \\
\hline Rogers 1998 & $\begin{array}{l}\text { This is a comparison of active versus expectant management of the third stage of labour and so is } \\
\text { included in the Cochrane review of this topic. }\end{array}$ \\
\hline Schindler 1981 & $\begin{array}{l}\text { This study compared clamped and unclamped cord management rather than early versus late tim- } \\
\text { ing of cord clamping. Note that although the full paper was in German, a translator was available; it } \\
\text { was determined from the English abstract that this study could not be included. }\end{array}$
\end{tabular}




\begin{tabular}{ll}
\hline Study & Reason for exclusion
\end{tabular}

Siddall 1953

Sorrells-Jones 1982
Quasi-randomised: "in the first half of the experiment the boys cords were milked, while 50 girls had prompt clamping and ligation at delivery. The sexes were reversed for the second 100".
It was not clear how many women were randomised to each group in this study comparing the Leboyer method with routine care. More than half of the sample were excluded post-randomisation. Women in the intervention group received a package of care which included delayed cord clamping along with other interventions and the impact of cord clamping is not clear.

\begin{tabular}{ll}
\hline Taylor 1963 & Quasi-randomised: allocation method by rotation. \\
\hline Terry 1970 & Quasi-randomised: allocation method by alternation. \\
\hline Thilaganathan 1993 & $\begin{array}{l}\text { This is a comparison of active versus expectant management of the third stage of labour and so is } \\
\text { included in the Cochrane review of this topic. }\end{array}$ \\
\hline Walsh 1968 & No mention of randomisation and allocation process not described. \\
\hline Walsh 1969 & No mention of randomisation and allocation process not described. \\
\hline Whipple 1957 & Allocation method, by rotation, open to bias. \\
\hline Wu 1960 & Quasi-randomised: allocation method by alternation. \\
\hline Yao 1971 & No mention of randomisation and allocation process not described. \\
\hline Yao 1977 & It was not clear that this was an RCT. No mention of random allocation to groups. Study concerned \\
with effects of timing of cord clamping on systolic time intervals of the newborn infant
\end{tabular}

RCT: randomised controlled trial

Characteristics of studies awaiting assessment [ordered by study ID]

Jaleel 2009

\begin{tabular}{|c|c|}
\hline Methods & Not clear. \\
\hline Participants & 200 women admitted in labour to a hospital in Karachi. \\
\hline Interventions & $\begin{array}{l}\text { Group 1: umbilical cord clamped immediately after birth. } \\
\text { Group 2: umbilical cord clamped after cessation of pulsation. }\end{array}$ \\
\hline Outcomes & Newborn haemoglobin and bilirubin. \\
\hline Notes & $\begin{array}{l}\text { We are awaiting further information on the methods for this study; it was not clear that there was } \\
\text { random allocation to groups. More than half of the sample were post-randomisation exclusions } \\
\text { and the remaining sample did not appear to be random (for example } 65 \% \text { of the babies were male). } \\
\text { It is stated that is a randomised trial but the authors also state: } \\
\text { " } 447 \text { deliveries were conducted in the Department. Problems were encountered as patients at Lyari } \\
\text { General Hospital tend to leave early after normal deliveries and therefore, obtaining the second } \\
\text { blood sample was difficult. Patients with incomplete data were excluded from the study. Finally, } \\
200 \text { patients were included, } 100 \text { in each group." }\end{array}$ \\
\hline
\end{tabular}


Li 2012

\begin{tabular}{ll}
\hline Methods & RCT. \\
\hline Participants & 158 mother-infant pairs. \\
\hline Interventions & Early cord clamping (15 seconds) versus late cord clamping (1 minute). \\
\hline Outcomes & Infant iron stores at 4 months. \\
\hline Notes & Requires translation. \\
\hline
\end{tabular}

\section{Nardozza 2012}

\begin{tabular}{ll}
\hline Methods & RCT reported in brief abstract. \\
\hline Participants & 50 women giving birth in a hospital in Brazil (not clear). \\
\hline Interventions & Immediate cord clamping versus spontaneous draining of the cord before clamping (not clear). \\
\hline Outcomes & Fetal blood cells entering maternal circulation. \\
\hline Notes & $\begin{array}{l}\text { This study was reported in a brief abstract and there was insufficient information to allow us assess } \\
\text { eligibility. We are awaiting publication of a full report of this trial. }\end{array}$ \\
\hline
\end{tabular}

Ping 2010

\begin{tabular}{ll}
\hline Methods & Not clear. Trial registration with no information on study methods. \\
\hline Participants & All live births. \\
\hline Interventions & $\begin{array}{l}\text { Immediate (within } 10 \text { seconds of birth) umbilical cord clamping versus clamping after the cord has } \\
\text { ceased pulsing. }\end{array}$ \\
\hline Outcomes & Infant haemoglobin at one month. \\
\hline Notes & $\begin{array}{l}\text { Hainan Medical College, China. Chief investigator Professor Hua Shao Ping. We will assess eligibility } \\
\text { once findings are published. }\end{array}$ \\
\hline
\end{tabular}

$\mathrm{RCT}$ : randomised controlled trial

Characteristics of ongoing studies [ordered by study ID]

\section{Beal 2006}

\begin{tabular}{ll}
\hline Trial name or title & Timing of cord clamping and neonatal haemoglobin - NCT00371228. \\
\hline Methods & 150 women presenting for vaginal birth at Tulsa Regional Medical Centre, Oklahoma, USA. \\
\hline Participants & 1) Clamping of umbilical cord within 6 seconds of delivery of the fetal shoulders.
\end{tabular}


Beal 2006 (Continued)

2) Clamping the cord after a palpable pulse has ceased, or after 10 minutes.

\begin{tabular}{ll}
\hline Outcomes & Neonatal haemoglobin. \\
\hline Starting date & September 2006. \\
\hline Contact information & $\begin{array}{l}\text { John M Beal; } \\
\text { Sarah J McCoy, Oklahoma State University Center for Health Sciences } \\
\text { email: sjmccoy98@aol.com }\end{array}$ \\
\hline Notes & \\
\hline
\end{tabular}

Hanson 2012

\begin{tabular}{ll}
\hline Trial name or title & $\begin{array}{l}\text { Effect of delayed cord clamping on the haemoglobin levels of term newborn Aboriginal communi- } \\
\text { ties: A pilot randomised trial. }\end{array}$ \\
\hline Methods & Proposed pilot RCT. \\
\hline Participants & 72 Aboriginal women at 36-42 weeks' gestation with uncomplicated vaginal or caesarean birth. \\
\hline Interventions & $\begin{array}{l}\text { Delayed cord clamping until pulsation ceases or after } 3 \text { minutes with baby held below the level of } \\
\text { the placenta verus standard care (immediate cord clamping). }\end{array}$ \\
\hline Outcomes & $\begin{array}{l}\text { Infant haemoglobin at time of hospital discharge, neonatal morbidity, Apgar score at } 5 \text { minutes, } \\
\text { neonatal death. }\end{array}$ \\
\hline Starting date & Starting date not clear. Proposed end date 29.02.12. \\
\hline Contact information & melanie.hanson@menzies.edu.au \\
\hline Notes & Proposed study reported in a brief conference abstract. \\
\hline
\end{tabular}

$\mathrm{RCT}$ : randomised controlled trial

\section{DATA AND ANALYSES}

\section{Comparison 1. Early versus late cord clamping}

\begin{tabular}{lllll}
\hline Outcome or subgroup title & No. of studies & $\begin{array}{l}\text { No. of partici- } \\
\text { pants }\end{array}$ & Statistical method & Effect size \\
\hline $\begin{array}{l}1 \text { Severe PPH/blood loss } 1000 \\
\text { mL or more }\end{array}$ & 5 & 2066 & Risk Ratio (M-H, Fixed, 95\% Cl) & $1.04[0.65,1.65]$ \\
\hline $\begin{array}{l}1.1 \text { Uterotonic before clamp- } \\
\text { ing }\end{array}$ & 1 & 480 & Risk Ratio (M-H, Fixed, 95\% Cl) & $1.16[0.46,2.96]$ \\
\hline $\begin{array}{l}1.2 \text { Uterotonic at, or after, } \\
\text { clamping }\end{array}$ & 3 & 956 & Risk Ratio (M-H, Fixed, 95\% Cl) & $1.06[0.57,1.95]$ \\
\hline
\end{tabular}




\begin{tabular}{|c|c|c|c|c|}
\hline Outcome or subgroup title & No. of studies & $\begin{array}{l}\text { No. of partici- } \\
\text { pants }\end{array}$ & Statistical method & Effect size \\
\hline $\begin{array}{l}1.3 \text { Use of uterotonic not spec- } \\
\text { ified }\end{array}$ & 2 & 630 & Risk Ratio (M-H, Fixed, 95\% Cl) & $0.85[0.29,2.49]$ \\
\hline 2 Neonatal death & 2 & 381 & Risk Ratio (M-H, Fixed, 95\% Cl) & $0.37[0.04,3.41]$ \\
\hline $\begin{array}{l}3 \mathrm{PPH} / \text { blood loss } 500 \mathrm{~mL} \text { or } \\
\text { more }\end{array}$ & 5 & 2260 & Risk Ratio (M-H, Fixed, 95\% Cl) & $1.17[0.94,1.44]$ \\
\hline $\begin{array}{l}3.1 \text { Uterotonic before clamp- } \\
\text { ing }\end{array}$ & 2 & 1032 & Risk Ratio (M-H, Fixed, 95\% Cl) & $1.11[0.74,1.67]$ \\
\hline $\begin{array}{l}3.2 \text { Uterotonic at, or after, } \\
\text { clamping }\end{array}$ & 3 & 956 & Risk Ratio (M-H, Fixed, 95\% Cl) & $1.22[0.90,1.65]$ \\
\hline $\begin{array}{l}3.3 \text { Use of uterotonic not spec- } \\
\text { ified }\end{array}$ & 1 & 272 & Risk Ratio (M-H, Fixed, 95\% Cl) & $1.13[0.73,1.74]$ \\
\hline 4 Mean blood loss (mL) & 2 & 1345 & $\begin{array}{l}\text { Mean Difference (IV, Fixed, 95\% } \\
\mathrm{CI} \text { ) }\end{array}$ & $5.11[-23.18,33.39]$ \\
\hline $\begin{array}{l}4.1 \text { Uterotonic before clamp- } \\
\text { ing }\end{array}$ & 1 & 480 & $\begin{array}{l}\text { Mean Difference (IV, Fixed, 95\% } \\
\mathrm{Cl} \text { ) }\end{array}$ & $22.0[-40.16,84.16]$ \\
\hline $\begin{array}{l}4.2 \text { Uterotonic at, or after, } \\
\text { clamping }\end{array}$ & 2 & 865 & $\begin{array}{l}\text { Mean Difference (IV, Fixed, 95\% } \\
\mathrm{CI} \text { ) }\end{array}$ & $0.70[-31.06,32.46]$ \\
\hline $\begin{array}{l}5 \text { Maternal haemoglobin (g/ } \\
\mathrm{dL} \text { ) } 24 \text { to } 72 \text { hours postpartum }\end{array}$ & 3 & 1128 & $\begin{array}{l}\text { Mean Difference (IV, Fixed, 95\% } \\
\mathrm{CI} \text { ) }\end{array}$ & $-0.12[-0.30,0.06]$ \\
\hline $\begin{array}{l}5.1 \text { Uterotonic before clamp- } \\
\text { ing }\end{array}$ & 1 & 480 & $\begin{array}{l}\text { Mean Difference (IV, Fixed, 95\% } \\
\mathrm{CI} \text { ) }\end{array}$ & $0.0[-0.31,0.31]$ \\
\hline $\begin{array}{l}5.2 \text { Uterotonic at, or after, } \\
\text { clamping }\end{array}$ & 1 & 483 & $\begin{array}{l}\text { Mean Difference (IV, Fixed, 95\% } \\
\mathrm{CI} \text { ) }\end{array}$ & $-0.10[-0.42,0.22]$ \\
\hline $\begin{array}{l}5.3 \text { Use of uterotonic not spec- } \\
\text { ified }\end{array}$ & 2 & 165 & $\begin{array}{l}\text { Mean Difference (IV, Fixed, 95\% } \\
\mathrm{CI})\end{array}$ & $-0.28[-0.60,0.04]$ \\
\hline 6 Need for blood transfusion & 2 & 1345 & Risk Ratio (M-H, Fixed, 95\% Cl) & $1.02[0.44,2.37]$ \\
\hline $\begin{array}{l}6.1 \text { Uterotonic before clamp- } \\
\text { ing }\end{array}$ & 1 & 480 & Risk Ratio (M-H, Fixed, 95\% Cl) & $1.55[0.26,9.20]$ \\
\hline $\begin{array}{l}6.2 \text { Uterotonic at, or after, } \\
\text { clamping }\end{array}$ & 2 & 865 & Risk Ratio (M-H, Fixed, 95\% Cl) & $0.89[0.34,2.35]$ \\
\hline $\begin{array}{l}7 \text { Need for manual removal of } \\
\text { placenta }\end{array}$ & 2 & 1515 & Risk Ratio (M-H, Fixed, 95\% Cl) & $1.59[0.78,3.26]$ \\
\hline $\begin{array}{l}7.1 \text { Uterotonic before clamp- } \\
\text { ing }\end{array}$ & 2 & 1032 & Risk Ratio (M-H, Fixed, 95\% Cl) & $2.17[0.94,5.01]$ \\
\hline $\begin{array}{l}7.2 \text { Uterotonic at, or after, } \\
\text { clamping }\end{array}$ & 1 & 483 & Risk Ratio (M-H, Fixed, 95\% Cl) & $0.49[0.09,2.65]$ \\
\hline
\end{tabular}




\begin{tabular}{|c|c|c|c|c|}
\hline Outcome or subgroup title & No. of studies & $\begin{array}{l}\text { No. of partici- } \\
\text { pants }\end{array}$ & Statistical method & Effect size \\
\hline $\begin{array}{l}8 \text { Length of third stage }>30 \\
\text { mins }\end{array}$ & 2 & 1345 & Risk Ratio (M-H, Fixed, 95\% Cl) & $1.18[0.55,2.52]$ \\
\hline $\begin{array}{l}8.1 \text { Uterotonic before clamp- } \\
\text { ing }\end{array}$ & 1 & 480 & Risk Ratio (M-H, Fixed, 95\% Cl) & $3.10[0.32,29.61]$ \\
\hline $\begin{array}{l}\text { 8.2 Uterotonic at, or after, } \\
\text { clamping }\end{array}$ & 2 & 865 & Risk Ratio (M-H, Fixed, 95\% Cl) & $1.01[0.44,2.29]$ \\
\hline $\begin{array}{l}9 \text { Length of third stage }>60 \\
\text { mins }\end{array}$ & 2 & 1345 & Risk Ratio (M-H, Random, 95\% Cl) & $1.11[0.33,3.74]$ \\
\hline $\begin{array}{l}9.1 \text { Uterotonic before clamp- } \\
\text { ing }\end{array}$ & 1 & 480 & Risk Ratio (M-H, Random, 95\% Cl) & $1.03[0.34,3.16]$ \\
\hline $\begin{array}{l}9.2 \text { Uterotonic at, or after } \\
\text { clamping }\end{array}$ & 2 & 865 & Risk Ratio (M-H, Random, 95\% Cl) & $1.68[0.09,31.66]$ \\
\hline $\begin{array}{l}10 \text { Need for therapeutic utero- } \\
\text { tonics }\end{array}$ & 1 & 963 & Risk Ratio (M-H, Fixed, 95\% Cl) & $0.94[0.74,1.20]$ \\
\hline $\begin{array}{l}10.1 \text { Uterotonic before clamp- } \\
\text { ing }\end{array}$ & 1 & 480 & Risk Ratio (M-H, Fixed, 95\% Cl) & $1.10[0.78,1.55]$ \\
\hline $\begin{array}{l}10.2 \text { Uterotonic at, or after, } \\
\text { clamping }\end{array}$ & 1 & 483 & Risk Ratio (M-H, Fixed, 95\% Cl) & $0.81[0.58,1.14]$ \\
\hline 11 Apgar score $<7$ at 5 mins & 3 & 1399 & Risk Ratio (M-H, Fixed, 95\% Cl) & $1.23[0.73,2.07]$ \\
\hline $\begin{array}{l}11.1 \text { Uterotonic before clamp- } \\
\text { ing }\end{array}$ & 1 & 480 & Risk Ratio (M-H, Fixed, 95\% Cl) & $1.72[0.42,7.13]$ \\
\hline $\begin{array}{l}11.2 \text { Uterotonic at, or after, } \\
\text { clamping }\end{array}$ & 2 & 540 & Risk Ratio (M-H, Fixed, 95\% Cl) & $1.96[0.60,6.42]$ \\
\hline $\begin{array}{l}11.3 \text { Use of uterotonic not } \\
\text { specified }\end{array}$ & 1 & 379 & Risk Ratio (M-H, Fixed, 95\% Cl) & $0.97[0.51,1.85]$ \\
\hline $\begin{array}{l}12 \text { Any admission to SCN or } \\
\text { NICU }\end{array}$ & 4 & 1675 & Risk Ratio (M-H, Fixed, 95\% Cl) & $0.79[0.48,1.31]$ \\
\hline $\begin{array}{l}12.1 \text { Uterotonic before clamp- } \\
\text { ing }\end{array}$ & 1 & 480 & Risk Ratio (M-H, Fixed, 95\% Cl) & $1.45[0.47,4.50]$ \\
\hline $\begin{array}{l}12.2 \text { Uterotonic at, or after, } \\
\text { clamping }\end{array}$ & 2 & 865 & Risk Ratio (M-H, Fixed, 95\% Cl) & $0.74[0.37,1.46]$ \\
\hline $\begin{array}{l}12.3 \text { Use of uterotonic not } \\
\text { specified }\end{array}$ & 2 & 330 & Risk Ratio (M-H, Fixed, 95\% Cl) & $0.57[0.20,1.60]$ \\
\hline 13 Respiratory distress & 3 & 835 & Risk Ratio (M-H, Random, 95\% Cl) & $0.70[0.22,2.19]$ \\
\hline $\begin{array}{l}14 \text { Jaundice requiring pho- } \\
\text { totherapy }\end{array}$ & 7 & 2324 & Risk Ratio (M-H, Fixed, 95\% Cl) & $0.62[0.41,0.96]$ \\
\hline
\end{tabular}




\begin{tabular}{|c|c|c|c|c|}
\hline Outcome or subgroup title & No. of studies & $\begin{array}{l}\text { No. of partici- } \\
\text { pants }\end{array}$ & Statistical method & Effect size \\
\hline $\begin{array}{l}14.1 \text { Uterotonic before clamp- } \\
\text { ing }\end{array}$ & 2 & 1032 & Risk Ratio (M-H, Fixed, 95\% Cl) & $0.59[0.32,1.11]$ \\
\hline $\begin{array}{l}14.2 \text { Uterotonic at, or after, } \\
\text { clamping }\end{array}$ & 5 & 1112 & Risk Ratio (M-H, Fixed, 95\% Cl) & $0.64[0.35,1.18]$ \\
\hline $\begin{array}{l}\text { 14.3 Use of uterotonic not } \\
\text { specified }\end{array}$ & 1 & 180 & Risk Ratio (M-H, Fixed, 95\% Cl) & $1.0[0.06,15.74]$ \\
\hline 15 Clinical jaundice & 6 & 2098 & Risk Ratio (M-H, Fixed, 95\% Cl) & $0.84[0.66,1.07]$ \\
\hline $\begin{array}{l}15.1 \text { Uterotonic before clamp- } \\
\text { ing }\end{array}$ & 2 & 1022 & Risk Ratio (M-H, Fixed, 95\% Cl) & $0.86[0.62,1.18]$ \\
\hline $\begin{array}{l}15.2 \text { Uterotonic at, or after, } \\
\text { clamping }\end{array}$ & 2 & 576 & Risk Ratio (M-H, Fixed, 95\% Cl) & $0.87[0.57,1.31]$ \\
\hline $\begin{array}{l}15.3 \text { Use of uterotonic not } \\
\text { specified }\end{array}$ & 3 & 500 & Risk Ratio (M-H, Fixed, 95\% Cl) & $0.64[0.29,1.39]$ \\
\hline 16 Polycythaemia & 5 & 1025 & Risk Ratio (M-H, Fixed, 95\% Cl) & $0.39[0.12,1.27]$ \\
\hline $\begin{array}{l}16.1 \text { Uterotonic at, or after, } \\
\text { clamping }\end{array}$ & 3 & 577 & Risk Ratio (M-H, Fixed, 95\% Cl) & $0.38[0.06,2.48]$ \\
\hline $\begin{array}{l}\text { 16.2 Use of uterotonic not } \\
\text { specified }\end{array}$ & 2 & 448 & Risk Ratio (M-H, Fixed, 95\% Cl) & $0.40[0.09,1.80]$ \\
\hline 17 Cord haemoglobin (g/dL) & 5 & 696 & $\begin{array}{l}\text { Mean Difference (IV, Fixed, 95\% } \\
\mathrm{CI} \text { ) }\end{array}$ & $0.41[0.15,0.66]$ \\
\hline $\begin{array}{l}17.1 \text { Uterotonic at, or after, } \\
\text { clamping }\end{array}$ & 3 & 531 & $\begin{array}{l}\text { Mean Difference (IV, Fixed, 95\% } \\
\mathrm{CI} \text { ) }\end{array}$ & $0.48[0.19,0.76]$ \\
\hline $\begin{array}{l}\text { 17.2 Use of uterotonic not } \\
\text { specified }\end{array}$ & 2 & 165 & $\begin{array}{l}\text { Mean Difference (IV, Fixed, 95\% } \\
\mathrm{CI} \text { ) }\end{array}$ & $0.15[-0.42,0.71]$ \\
\hline $\begin{array}{l}18 \text { Newborn haemoglobin (g/ } \\
\mathrm{dL} \text { ) }\end{array}$ & 3 & 671 & $\begin{array}{l}\text { Mean Difference (IV, Random, } \\
95 \% \mathrm{CI})\end{array}$ & $-2.17[-4.06,-0.28]$ \\
\hline $\begin{array}{l}18.1 \text { Uterotonic at, or after, } \\
\text { clamping }\end{array}$ & 1 & 45 & $\begin{array}{l}\text { Mean Difference (IV, Random, } \\
95 \% \mathrm{CI} \text { ) }\end{array}$ & $-4.45[-5.33,-3.57]$ \\
\hline $\begin{array}{l}\text { 18.2 Use of uterotonic not } \\
\text { specified }\end{array}$ & 2 & 626 & $\begin{array}{l}\text { Mean Difference (IV, Random, } \\
95 \% \mathrm{CI} \text { ) }\end{array}$ & $-1.07[-2.03,-0.12]$ \\
\hline $\begin{array}{l}19 \text { Infant haemoglobin at } \\
24-48 \text { hours }(\mathrm{g} / \mathrm{dL})\end{array}$ & 4 & 884 & $\begin{array}{l}\text { Mean Difference (IV, Fixed, 95\% } \\
\mathrm{CI} \text { ) }\end{array}$ & $-1.49[-1.78,-1.21]$ \\
\hline $\begin{array}{l}19.1 \text { Uterotonic at, or after, } \\
\text { clamping }\end{array}$ & 2 & 426 & $\begin{array}{l}\text { Mean Difference (IV, Fixed, 95\% } \\
\mathrm{CI} \text { ) }\end{array}$ & $-1.40[-1.75,-1.05]$ \\
\hline $\begin{array}{l}\text { 19.2 Use of uterotonic not } \\
\text { specified }\end{array}$ & 2 & 458 & $\begin{array}{l}\text { Mean Difference (IV, Fixed, 95\% } \\
\mathrm{CI} \text { ) }\end{array}$ & $-1.68[-2.18,-1.19]$ \\
\hline
\end{tabular}




\begin{tabular}{|c|c|c|c|c|}
\hline Outcome or subgroup title & No. of studies & $\begin{array}{l}\text { No. of partici- } \\
\text { pants }\end{array}$ & Statistical method & Effect size \\
\hline $\begin{array}{l}20 \text { Infant haemoglobin at 3-6 } \\
\text { months }(\mathrm{g} / \mathrm{dL})\end{array}$ & 6 & 1115 & $\begin{array}{l}\text { Mean Difference (IV, Random, } \\
95 \% \mathrm{CI} \text { ) }\end{array}$ & $-0.15[-0.48,0.19]$ \\
\hline $\begin{array}{l}20.1 \text { Uterotonic at, or after, } \\
\text { clamping }\end{array}$ & 2 & 434 & $\begin{array}{l}\text { Mean Difference (IV, Random, } \\
95 \% \mathrm{CI} \text { ) }\end{array}$ & $0.03[-0.17,0.22]$ \\
\hline $\begin{array}{l}20.2 \text { Use of uterotonic not } \\
\text { specified }\end{array}$ & 4 & 681 & $\begin{array}{l}\text { Mean Difference (IV, Random, } \\
95 \% \mathrm{CI})\end{array}$ & $-0.26[-0.79,0.26]$ \\
\hline $\begin{array}{l}21 \text { Low infant haemoglobin at } \\
3-6 \text { months }\end{array}$ & 4 & 954 & Risk Ratio (M-H, Fixed, 95\% Cl) & $1.05[0.79,1.39]$ \\
\hline $\begin{array}{l}21.1 \text { Uterotonic at, or after, } \\
\text { clamping }\end{array}$ & 2 & 438 & Risk Ratio (M-H, Fixed, 95\% Cl) & $0.96[0.67,1.36]$ \\
\hline $\begin{array}{l}21.2 \text { Use of uterotonic not } \\
\text { specified }\end{array}$ & 2 & 516 & Risk Ratio (M-H, Fixed, 95\% Cl) & $1.19[0.74,1.92]$ \\
\hline 22 Infant haematocrit (\%) & 1 & & $\begin{array}{l}\text { Mean Difference (IV, Fixed, 95\% } \\
\mathrm{CI} \text { ) }\end{array}$ & Subtotals only \\
\hline 22.1 At 24 hours & 1 & 180 & $\begin{array}{l}\text { Mean Difference (IV, Fixed, 95\% } \\
\mathrm{CI} \text { ) }\end{array}$ & $-4.40[-5.71,-3.09]$ \\
\hline 22.2 At 3-5 months & 1 & 160 & $\begin{array}{l}\text { Mean Difference (IV, Fixed, 95\% } \\
\mathrm{CI} \text { ) }\end{array}$ & $-0.40[-1.48,0.68]$ \\
\hline $\begin{array}{l}23 \text { Low infant haematocrit (< } \\
45 \% \text { at } 6 \text { hours) }\end{array}$ & 1 & 272 & Risk Ratio (M-H, Fixed, 95\% Cl) & $16.18[2.05,127.37]$ \\
\hline $\begin{array}{l}23.1 \text { Use of uterotonic not } \\
\text { specified }\end{array}$ & 1 & 272 & Risk Ratio (M-H, Fixed, 95\% Cl) & $16.18[2.05,127.37]$ \\
\hline $\begin{array}{l}24 \text { Low infant haematocrit (< } \\
45 \% \text { at } 24-48 \text { hours) }\end{array}$ & 1 & 268 & Risk Ratio (M-H, Fixed, 95\% Cl) & $6.03[2.27,16.07]$ \\
\hline $\begin{array}{l}24.1 \text { Use of uterotonic not } \\
\text { specified }\end{array}$ & 1 & 268 & Risk Ratio (M-H, Fixed, 95\% Cl) & $6.03[2.27,16.07]$ \\
\hline $\begin{array}{l}25 \text { Infant iron deficiency at 3-6 } \\
\text { months }\end{array}$ & 5 & 1152 & Risk Ratio (M-H, Random, 95\% Cl) & $2.65[1.04,6.73]$ \\
\hline $\begin{array}{l}25.1 \text { Uterotonic at, or after, } \\
\text { clamping }\end{array}$ & 2 & 425 & Risk Ratio (M-H, Random, 95\% Cl) & $2.73[0.19,40.19]$ \\
\hline $\begin{array}{l}25.2 \text { Use of uterotonic not } \\
\text { specified }\end{array}$ & 3 & 727 & Risk Ratio (M-H, Random, 95\% Cl) & $2.91[1.18,7.20]$ \\
\hline 26 Birthweight (g) & 12 & 3139 & $\begin{array}{l}\text { Mean Difference (IV, Random, } \\
95 \% \mathrm{CI})\end{array}$ & $\begin{array}{l}-101.18[-157.59 \\
-44.76]\end{array}$ \\
\hline $\begin{array}{l}27 \text { Not breastfeeding on dis- } \\
\text { charge (or later) }\end{array}$ & 9 & & Risk Ratio (M-H, Fixed, 95\% Cl) & Subtotals only \\
\hline 27.1 At discharge & 4 & 1633 & Risk Ratio (M-H, Fixed, 95\% Cl) & $1.11[0.90,1.36]$ \\
\hline
\end{tabular}




\begin{tabular}{|c|c|c|c|c|}
\hline Outcome or subgroup title & No. of studies & $\begin{array}{l}\text { No. of partici- } \\
\text { pants }\end{array}$ & Statistical method & Effect size \\
\hline 27.2 At 1 month & 1 & 268 & Risk Ratio (M-H, Fixed, 95\% Cl) & $1.10[1.00,1.20]$ \\
\hline 27.3 At 2 months & 1 & 84 & Risk Ratio (M-H, Fixed, 95\% Cl) & $0.21[0.01,4.24]$ \\
\hline 27.4 At 3 months & 2 & 144 & Risk Ratio (M-H, Fixed, 95\% Cl) & $0.93[0.36,2.42]$ \\
\hline 27.5 At 4 months & 2 & 391 & Risk Ratio (M-H, Fixed, 95\% Cl) & $0.88[0.74,1.04]$ \\
\hline 27.6 At 6 months & 2 & 430 & Risk Ratio (M-H, Fixed, 95\% Cl) & $0.99[0.89,1.11]$ \\
\hline $\begin{array}{l}28 \text { Neurodevelopment at } 4 \\
\text { months }\end{array}$ & 1 & & $\begin{array}{l}\text { Mean Difference (IV, Fixed, 95\% } \\
\mathrm{CI} \text { ) }\end{array}$ & Subtotals only \\
\hline 28.1 ASQ total score & 1 & 365 & $\begin{array}{l}\text { Mean Difference (IV, Fixed, 95\% } \\
\mathrm{CI} \text { ) }\end{array}$ & $-1.40[-7.31,4.51]$ \\
\hline $\begin{array}{l}28.2 \text { ASQ communication } \\
\text { score }\end{array}$ & 1 & 365 & $\begin{array}{l}\text { Mean Difference (IV, Fixed, 95\% } \\
\mathrm{CI} \text { ) }\end{array}$ & $-0.30[-1.87,1.27]$ \\
\hline 28.3 ASQ gross motor score & 1 & 365 & $\begin{array}{l}\text { Mean Difference (IV, Fixed, 95\% } \\
\mathrm{Cl} \text { ) }\end{array}$ & $-0.60[-2.11,0.91]$ \\
\hline 28.4 ASQ fine motor score & 1 & 365 & $\begin{array}{l}\text { Mean Difference (IV, Fixed, 95\% } \\
\mathrm{Cl} \text { ) }\end{array}$ & $-0.90[-3.10,1.30]$ \\
\hline $\begin{array}{l}28.5 \text { ASQ problem-solving } \\
\text { score }\end{array}$ & 1 & 365 & $\begin{array}{l}\text { Mean Difference (IV, Fixed, 95\% } \\
\mathrm{CI})\end{array}$ & $-1.80[-3.38,-0.22]$ \\
\hline 28.6 ASQ personal-social score & 1 & 365 & $\begin{array}{l}\text { Mean Difference (IV, Fixed, 95\% } \\
\mathrm{CI})\end{array}$ & $2.30[0.51,4.09]$ \\
\hline $\begin{array}{l}29 \text { Symptoms of infection dur- } \\
\text { ing first } 4 \text { months }\end{array}$ & 1 & & Risk Ratio (M-H, Fixed, 95\% Cl) & Subtotals only \\
\hline 29.1 Fever & 1 & 360 & Risk Ratio (M-H, Fixed, 95\% Cl) & $0.92[0.64,1.31]$ \\
\hline 29.2 Diarrhoea & 1 & 360 & Risk Ratio (M-H, Fixed, 95\% Cl) & $1.12[0.57,2.19]$ \\
\hline 29.3 Loose stools & 1 & 360 & Risk Ratio (M-H, Fixed, 95\% Cl) & $0.85[0.57,1.27]$ \\
\hline 29.4 Hard stools & 1 & 360 & Risk Ratio (M-H, Fixed, 95\% Cl) & $0.78[0.28,2.21]$ \\
\hline 29.5 Belly ache & 1 & 360 & Risk Ratio (M-H, Fixed, 95\% Cl) & $1.18[0.81,1.71]$ \\
\hline 29.6 Vomiting & 1 & 360 & Risk Ratio (M-H, Fixed, 95\% Cl) & $1.38[0.79,2.41]$ \\
\hline 29.7 Cough & 1 & 360 & Risk Ratio (M-H, Fixed, 95\% Cl) & $0.94[0.72,1.23]$ \\
\hline 29.8 Breathing difficulties & 1 & 360 & Risk Ratio (M-H, Fixed, 95\% Cl) & $0.80[0.40,1.60]$ \\
\hline 29.9 Rhinorrhea/runny nose & 1 & 360 & Risk Ratio (M-H, Fixed, 95\% Cl) & $0.94[0.69,1.28]$ \\
\hline 29.10 Nasal congestion & 1 & 360 & Risk Ratio (M-H, Fixed, 95\% Cl) & $1.07[0.89,1.27]$ \\
\hline
\end{tabular}




\begin{tabular}{lllll}
\hline Outcome or subgroup title & No. of studies & $\begin{array}{l}\text { No. of partici- } \\
\text { pants }\end{array}$ & Statistical method & Effect size \\
\hline 29.11 Otitis & 1 & 360 & Risk Ratio (M-H, Fixed, 95\% Cl) & $0.70[0.12,4.12]$ \\
\hline 29.12 Rash & 1 & 360 & Risk Ratio (M-H, Fixed, 95\% Cl) & $0.97[0.59,1.60]$ \\
\hline 29.13 Crying & 1 & 360 & Risk Ratio (M-H, Fixed, 95\% Cl) & $1.37[0.95,1.96]$ \\
\hline 29.14 Tiredness & 1 & 360 & Risk Ratio (M-H, Fixed, 95\% Cl) & $1.17[0.71,1.93]$ \\
\hline 29.15 Visit to paediatrician & 1 & 360 & Risk Ratio (M-H, Fixed, 95\% Cl) & $0.83[0.56,1.23]$ \\
\hline 29.16 Visit to other doctor & 1 & 360 & Risk Ratio (M-H, Fixed, 95\% Cl) & $1.19[0.60,2.37]$ \\
\hline 29.17 Antibiotics & 1 & 360 & Risk Ratio (M-H, Fixed, 95\% Cl) & $1.36[0.61,3.02]$ \\
\hline 29.18 Admitted to hospital & 1 & 360 & Risk Ratio (M-H, Fixed, 95\% Cl) & $1.46[0.67,3.21]$ \\
\hline
\end{tabular}

Analysis 1.1. Comparison 1 Early versus late cord clamping, Outcome 1 Severe PPH/blood loss $1000 \mathrm{~mL}$ or more.

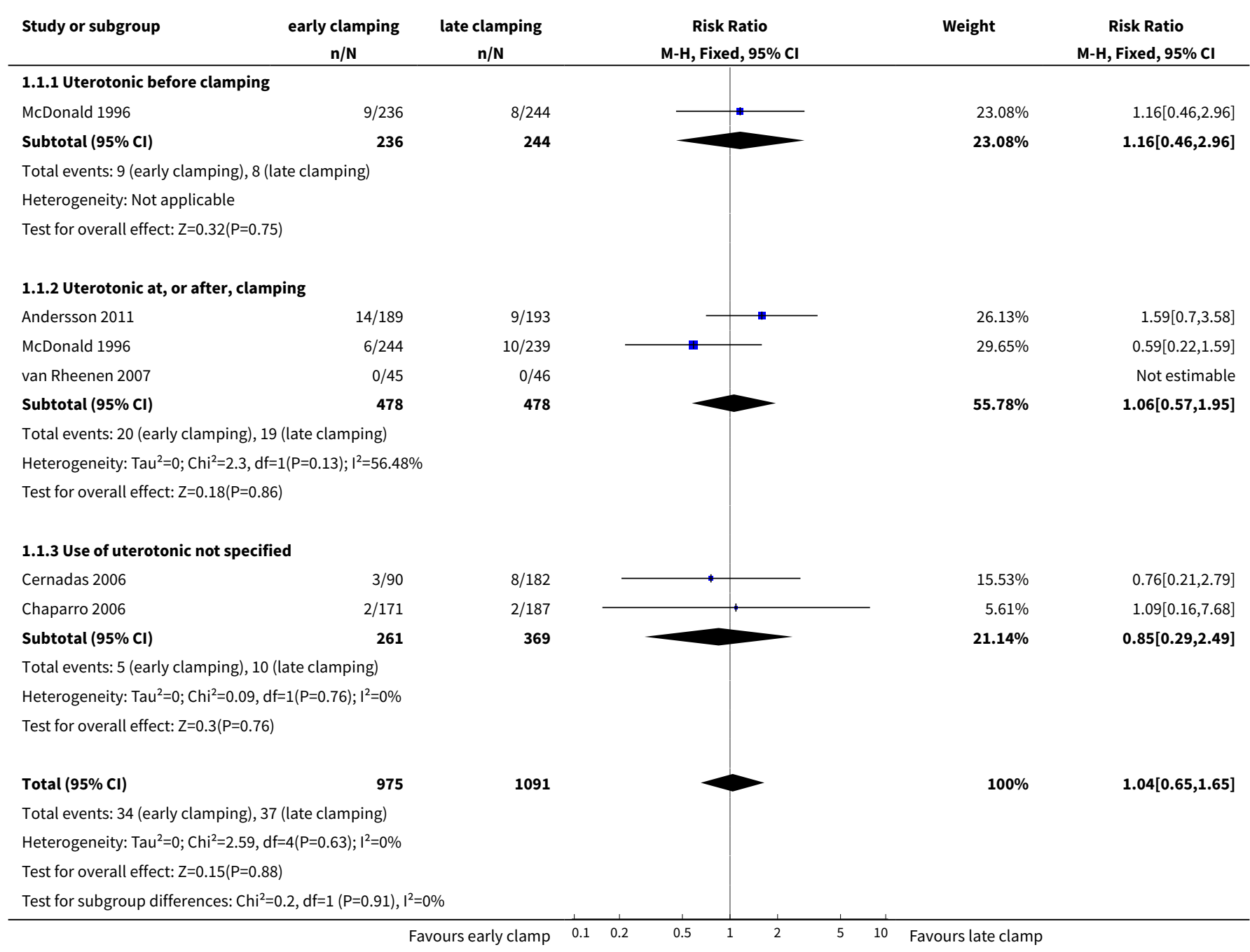


Analysis 1.2. Comparison 1 Early versus late cord clamping, Outcome 2 Neonatal death.

\begin{tabular}{|c|c|c|c|c|c|}
\hline Study or subgroup & $\begin{array}{c}\text { early clamping } \\
n / N\end{array}$ & $\begin{array}{c}\text { late clamping } \\
\mathrm{n} / \mathrm{N}\end{array}$ & $\begin{array}{c}\text { Risk Ratio } \\
\text { M-H, Fixed, } 95 \% \text { Cl }\end{array}$ & Weight & $\begin{array}{c}\text { Risk Ratio } \\
\text { M-H, Fixed, } 95 \% \mathrm{Cl} \\
\end{array}$ \\
\hline Cernadas 2006 & $0 / 92$ & $0 / 184$ & & & Not estimable \\
\hline van Rheenen 2007 & $1 / 50$ & $3 / 55$ & 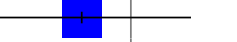 & $100 \%$ & $0.37[0.04,3.41]$ \\
\hline Total $(95 \% \mathrm{Cl})$ & 142 & 239 & & $100 \%$ & $0.37[0.04,3.41]$ \\
\hline \multicolumn{6}{|c|}{ Total events: 1 (early clamping), 3 (late clamping) } \\
\hline \multicolumn{6}{|c|}{ Heterogeneity: Not applicable } \\
\hline \multicolumn{6}{|c|}{ Test for overall effect: $\mathrm{Z}=0.88(\mathrm{P}=0.38)$} \\
\hline
\end{tabular}

Analysis 1.3. Comparison 1 Early versus late cord clamping, Outcome $3 \mathrm{PPH} / \mathrm{blood}$ loss $500 \mathrm{~mL}$ or more.

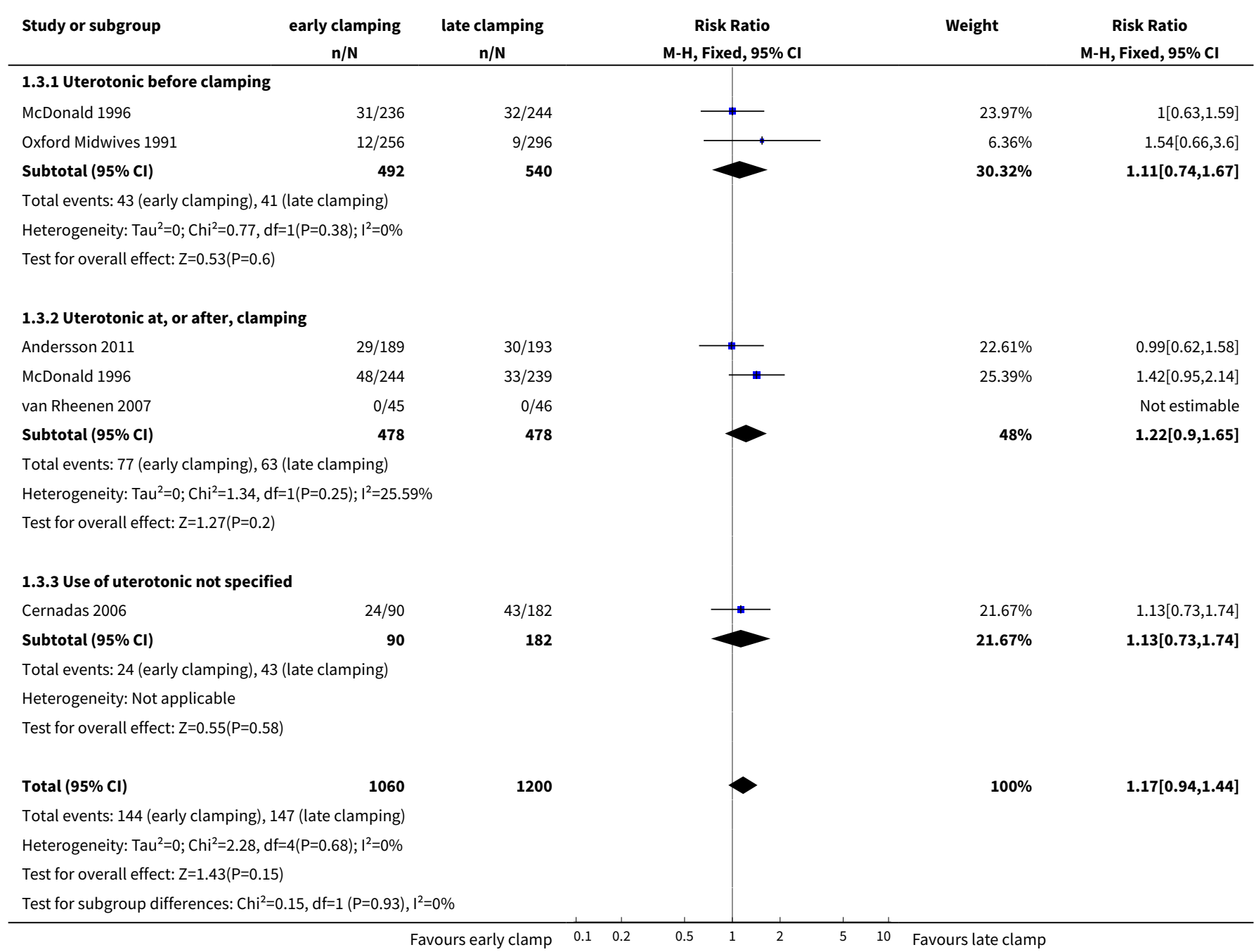


Analysis 1.4. Comparison 1 Early versus late cord clamping, Outcome 4 Mean blood loss ( $\mathrm{mL}$ ).

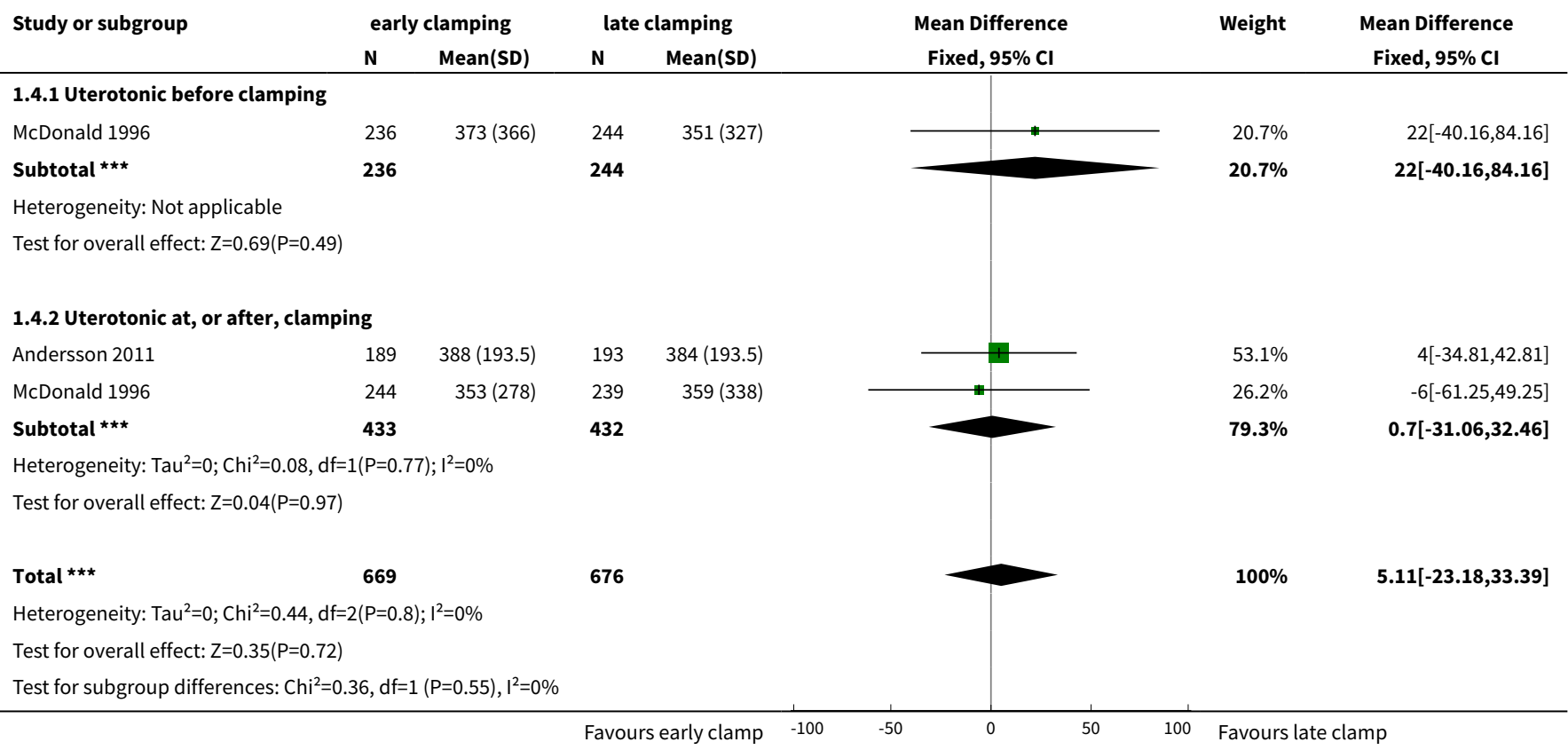

Analysis 1.5. Comparison 1 Early versus late cord clamping, Outcome 5 Maternal haemoglobin $(\mathrm{g} / \mathrm{dL}) 24$ to 72 hours postpartum.

\begin{tabular}{|c|c|c|c|c|c|c|c|}
\hline \multirow[t]{2}{*}{ Study or subgroup } & \multicolumn{2}{|c|}{ early clamping } & \multicolumn{2}{|c|}{ late clamping } & \multirow{2}{*}{$\begin{array}{c}\text { Mean Difference } \\
\text { Fixed, } 95 \% \mathrm{Cl}\end{array}$} & \multirow[t]{2}{*}{ Weight } & \multirow{2}{*}{$\begin{array}{c}\text { Mean Difference } \\
\text { Fixed, } 95 \% \mathrm{Cl}\end{array}$} \\
\hline & $\mathbf{N}$ & $\operatorname{Mean}(S D)$ & $\mathbf{N}$ & $\operatorname{Mean}(S D)$ & & & \\
\hline \multicolumn{8}{|c|}{ 1.5.1 Uterotonic before clamping } \\
\hline McDonald 1996 & 236 & $10.8(1.8)$ & 244 & $10.8(1.6)$ & & $35.57 \%$ & $0[-0.31,0.31]$ \\
\hline 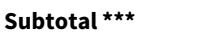 & 236 & & 244 & & & $35.57 \%$ & $0[-0.31,0.31]$ \\
\hline \multicolumn{8}{|c|}{ Heterogeneity: Not applicable } \\
\hline \multicolumn{8}{|c|}{ Test for overall effect: Not applicable } \\
\hline \multicolumn{8}{|c|}{ 1.5.2 Uterotonic at, or after, clamping } \\
\hline McDonald 1996 & 244 & $11.1(1.7)$ & 239 & $11.2(1.9)$ & \# & $31.97 \%$ & $-0.1[-0.42,0.22]$ \\
\hline 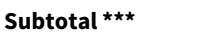 & 244 & & 239 & & & $31.97 \%$ & $-0.1[-0.42,0.22]$ \\
\hline \multicolumn{8}{|c|}{ Heterogeneity: Not applicable } \\
\hline \multicolumn{8}{|c|}{ Test for overall effect: $Z=0.61(P=0.54)$} \\
\hline Geethanath 1997 & 48 & $12.5(1.7)$ & 59 & $12.7(1.8)$ & $\longrightarrow$ & $7.48 \%$ & $-0.2[-0.87,0.47]$ \\
\hline Gupta 2002 & 29 & $8.9(0.8)$ & 29 & $9.2(0.6)$ & $\rightarrow$ & $24.98 \%$ & $-0.3[-0.66,0.06]$ \\
\hline Subtotal $* \star \star$ & 77 & & 88 & & & $32.47 \%$ & $-0.28[-0.6,0.04]$ \\
\hline \multicolumn{8}{|c|}{ Heterogeneity: Tau $^{2}=0 ; \mathrm{Chi}^{2}=0.07, \mathrm{df}=1(\mathrm{P}=0.8) ; \mathrm{I}^{2}=0 \%$} \\
\hline \multicolumn{8}{|c|}{ Test for overall effect: $Z=1.7(P=0.09)$} \\
\hline Total $\star \star \star ~$ & 557 & & 571 & & 4 & $100 \%$ & $-0.12[-0.3,0.06]$ \\
\hline \multicolumn{8}{|c|}{ Heterogeneity: $\mathrm{Tau}^{2}=0 ; \mathrm{Chi}^{2}=1.6, \mathrm{df}=3(\mathrm{P}=0.66) ; \mathrm{I}^{2}=0 \%$} \\
\hline \multicolumn{8}{|c|}{ Test for overall effect: $\mathrm{Z}=1.31(\mathrm{P}=0.19)$} \\
\hline \multicolumn{8}{|c|}{ Test for subgroup differences: $\mathrm{Chi}^{2}=1.54, \mathrm{df}=1(\mathrm{P}=0.46), \mathrm{I}^{2}=0 \%$} \\
\hline & & & Favo & late clamp $\quad-4$ & -2 & Favours & lamp \\
\hline
\end{tabular}




\section{Analysis 1.6. Comparison 1 Early versus late cord clamping, Outcome 6 Need for blood transfusion.}

\begin{tabular}{|c|c|c|c|c|c|}
\hline Study or subgroup & $\begin{array}{c}\text { early clamping } \\
n / N\end{array}$ & $\begin{array}{c}\text { late clamping } \\
\mathrm{n} / \mathrm{N}\end{array}$ & $\begin{array}{c}\text { Risk Ratio } \\
\text { M-H, Fixed, } 95 \% \mathrm{Cl} \\
\end{array}$ & Weight & $\begin{array}{c}\text { Risk Ratio } \\
\text { M-H, Fixed, } 95 \% \mathrm{Cl} \\
\end{array}$ \\
\hline \multicolumn{6}{|c|}{ 1.6.1 Uterotonic before clamping } \\
\hline McDonald 1996 & $3 / 236$ & $2 / 244$ & " & $18.86 \%$ & $1.55[0.26,9.2]$ \\
\hline Subtotal $(95 \% \mathrm{Cl})$ & 236 & 244 & & $18.86 \%$ & $1.55[0.26,9.2]$ \\
\hline \multicolumn{6}{|c|}{ Total events: 3 (early clamping), 2 (late clamping) } \\
\hline \multicolumn{6}{|c|}{ Heterogeneity: Not applicable } \\
\hline \multicolumn{6}{|c|}{ Test for overall effect: $Z=0.48(P=0.63)$} \\
\hline \multicolumn{6}{|c|}{ 1.6.2 Uterotonic at, or after, clamping } \\
\hline Andersson 2011 & $7 / 189$ & $6 / 193$ & + & $56.93 \%$ & $1.19[0.41,3.48]$ \\
\hline McDonald 1996 & $0 / 244$ & $2 / 239$ & & $24.22 \%$ & $0.2[0.01,4.06]$ \\
\hline Subtotal (95\% Cl) & 433 & 432 & & $81.14 \%$ & $0.89[0.34,2.35]$ \\
\hline \multicolumn{6}{|c|}{ Total events: 7 (early clamping), 8 (late clamping) } \\
\hline \multicolumn{6}{|c|}{ Heterogeneity: Tau $^{2}=0 ; \mathrm{Chi}^{2}=1.24, \mathrm{df}=1(\mathrm{P}=0.27) ; I^{2}=19.29 \%$} \\
\hline \multicolumn{6}{|c|}{ Test for overall effect: $Z=0.23(P=0.82)$} \\
\hline Total $(95 \% \mathrm{Cl})$ & 669 & 676 & & $100 \%$ & $1.02[0.44,2.37]$ \\
\hline \multicolumn{6}{|c|}{ Total events: 10 (early clamping), 10 (late clamping) } \\
\hline \multicolumn{6}{|c|}{ Heterogeneity: $\operatorname{Tau}^{2}=0 ; \mathrm{Chi}^{2}=1.43, \mathrm{df}=2(\mathrm{P}=0.49) ; 1^{2}=0 \%$} \\
\hline \multicolumn{6}{|c|}{ Test for overall effect: $\mathrm{Z}=0.04(\mathrm{P}=0.97)$} \\
\hline Test for subgroup dif & $.28, d f=1(P=0.59)$ & & & & \\
\hline
\end{tabular}

\section{Analysis 1.7. Comparison 1 Early versus late cord clamping, Outcome 7 Need for manual removal of placenta.}

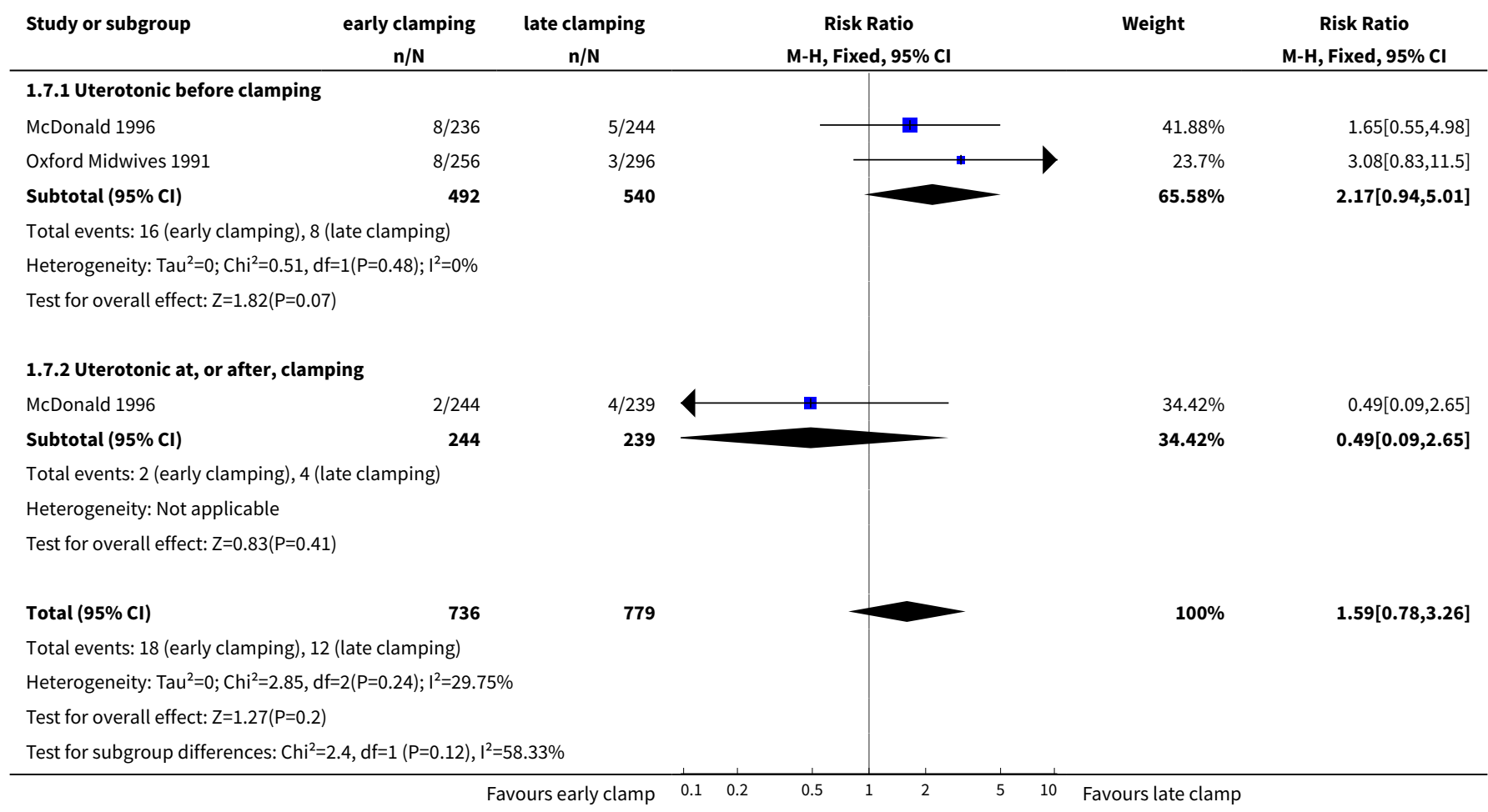


Analysis 1.8. Comparison 1 Early versus late cord clamping, Outcome 8 Length of third stage $>30$ mins.

\begin{tabular}{|c|c|c|c|c|c|}
\hline Study or subgroup & $\begin{array}{c}\text { early clamping } \\
n / N\end{array}$ & $\begin{array}{c}\text { late clamping } \\
n / N\end{array}$ & $\begin{array}{c}\text { Risk Ratio } \\
\text { M-H, Fixed, } 95 \% \mathrm{Cl}\end{array}$ & Weight & $\begin{array}{c}\text { Risk Ratio } \\
\text { M-H, Fixed, } 95 \% \mathrm{Cl}\end{array}$ \\
\hline \multicolumn{6}{|c|}{ 1.8.1 Uterotonic before clamping } \\
\hline McDonald 1996 & $3 / 236$ & $1 / 244$ & 4 & $8.23 \%$ & $3.1[0.32,29.61]$ \\
\hline Subtotal $(95 \% \mathrm{Cl})$ & 236 & 244 & & $8.23 \%$ & $3.1[0.32,29.61]$ \\
\hline \multicolumn{6}{|c|}{ Total events: 3 (early clamping), 1 (late clamping) } \\
\hline \multicolumn{6}{|c|}{ Heterogeneity: Not applicable } \\
\hline \multicolumn{6}{|c|}{ Test for overall effect: $\mathrm{Z}=0.98(\mathrm{P}=0.33)$} \\
\hline \multicolumn{6}{|c|}{ 1.8.2 Uterotonic at, or after, clamping } \\
\hline Andersson 2011 & $9 / 189$ & $7 / 193$ & \# & $57.96 \%$ & $1.31[0.5,3.45]$ \\
\hline McDonald 1996 & $2 / 244$ & $4 / 239$ & & $33.82 \%$ & $0.49[0.09,2.65]$ \\
\hline Subtotal (95\% Cl) & 433 & 432 & & $91.77 \%$ & $1.01[0.44,2.29]$ \\
\hline \multicolumn{6}{|c|}{ Total events: 11 (early clamping), 11 (late clamping) } \\
\hline \multicolumn{6}{|c|}{ Heterogeneity: $\operatorname{Tau}^{2}=0 ; \mathrm{Chi}^{2}=0.99, \mathrm{df}=1(\mathrm{P}=0.32) ; \mathrm{I}^{2}=0 \%$} \\
\hline \multicolumn{6}{|c|}{ Test for overall effect: $Z=0.02(P=0.98)$} \\
\hline Total $(95 \% \mathrm{Cl})$ & 669 & 676 & & $100 \%$ & $1.18[0.55,2.52]$ \\
\hline \multicolumn{6}{|c|}{ Total events: 14 (early clamping), 12 (late clamping) } \\
\hline \multicolumn{6}{|c|}{ Heterogeneity: Tau $^{2}=0 ; \mathrm{Chi}^{2}=1.79, \mathrm{df}=2(\mathrm{P}=0.41) ; \mathrm{I}^{2}=0 \%$} \\
\hline \multicolumn{6}{|c|}{ Test for overall effect: $Z=0.43(P=0.67)$} \\
\hline Test for subgroup dif & $0.84, d f=1(P=0.36)$, & & & & \\
\hline
\end{tabular}

Analysis 1.9. Comparison 1 Early versus late cord clamping, Outcome 9 Length of third stage $>60$ mins.

\begin{tabular}{|c|c|c|c|c|c|}
\hline Study or subgroup & $\begin{array}{l}\text { early clamping } \\
n / N\end{array}$ & $\begin{array}{c}\text { late clamping } \\
\mathrm{n} / \mathrm{N}\end{array}$ & $\begin{array}{c}\text { Risk Ratio } \\
\text { M-H, Random, } 95 \% \mathrm{Cl}\end{array}$ & Weight & $\begin{array}{c}\text { Risk Ratio } \\
\text { M-H, Random, } 95 \% \mathrm{Cl} \\
\end{array}$ \\
\hline \multicolumn{6}{|c|}{ 1.9.1 Uterotonic before clamping } \\
\hline McDonald 1996 & $6 / 236$ & $6 / 244$ & & $52.1 \%$ & $1.03[0.34,3.16]$ \\
\hline Subtotal $(95 \% \mathrm{Cl})$ & 236 & 244 & & $52.1 \%$ & $1.03[0.34,3.16]$ \\
\hline \multicolumn{6}{|c|}{ Total events: 6 (early clamping), 6 (late clamping) } \\
\hline \multicolumn{6}{|c|}{ Heterogeneity: Not applicable } \\
\hline \multicolumn{6}{|c|}{ Test for overall effect: $Z=0.06(P=0.95)$} \\
\hline \multicolumn{6}{|c|}{ 1.9.2 Uterotonic at, or after clamping } \\
\hline Andersson 2011 & $4 / 189$ & 0/193 & & $14.63 \%$ & $9.19[0.5,169.52]$ \\
\hline McDonald 1996 & $2 / 244$ & $4 / 239$ & 4 & $33.27 \%$ & $0.49[0.09,2.65]$ \\
\hline Subtotal $(95 \% \mathrm{Cl})$ & 433 & 432 & & $47.9 \%$ & $1.68[0.09,31.66]$ \\
\hline \multicolumn{6}{|c|}{ Total events: 6 (early clamping), 4 (late clamping) } \\
\hline \multicolumn{6}{|c|}{ Heterogeneity: $\mathrm{Tau}^{2}=3.13 ; \mathrm{Chi}^{2}=3.12, \mathrm{df}=1(\mathrm{P}=0.08) ; \mathrm{I}^{2}=67.95 \%$} \\
\hline \multicolumn{6}{|c|}{ Test for overall effect: $Z=0.35(P=0.73)$} \\
\hline Total $(95 \% \mathrm{Cl})$ & 669 & 676 & & $100 \%$ & $1.11[0.33,3.74]$ \\
\hline \multicolumn{6}{|c|}{ Total events: 12 (early clamping), 10 (late clamping) } \\
\hline \multicolumn{6}{|c|}{ Heterogeneity: $\mathrm{Tau}^{2}=0.41 ; \mathrm{Chi}^{2}=3.04, \mathrm{df}=2(\mathrm{P}=0.22) ; \mathrm{I}^{2}=34.15 \%$} \\
\hline \multicolumn{6}{|c|}{ Test for overall effect: $Z=0.17(P=0.87)$} \\
\hline Test for subgroup dif & $.09, d f=1(P=0.76)$, & & & & \\
\hline
\end{tabular}


Analysis 1.10. Comparison 1 Early versus late cord clamping, Outcome 10 Need for therapeutic uterotonics.

\begin{tabular}{|c|c|c|c|c|c|}
\hline Study or subgroup & $\begin{array}{c}\text { early clamping } \\
n / N\end{array}$ & $\begin{array}{c}\text { late clamping } \\
n / N\end{array}$ & $\begin{array}{c}\text { Risk Ratio } \\
\text { M-H, Fixed, } 95 \% \mathrm{Cl} \\
\end{array}$ & Weight & $\begin{array}{c}\text { Risk Ratio } \\
\text { M-H, Fixed, } 95 \% \mathrm{Cl} \\
\end{array}$ \\
\hline \multicolumn{6}{|c|}{ 1.10.1 Uterotonic before clamping } \\
\hline McDonald 1996 & $52 / 236$ & $49 / 244$ & & $45.12 \%$ & $1.1[0.78,1.55]$ \\
\hline Subtotal $(95 \% \mathrm{Cl})$ & 236 & 244 & & $45.12 \%$ & $1.1[0.78,1.55]$ \\
\hline \multicolumn{6}{|c|}{ Total events: 52 (early clamping), 49 (late clamping) } \\
\hline \multicolumn{6}{|c|}{ Heterogeneity: Not applicable } \\
\hline \multicolumn{6}{|c|}{ Test for overall effect: $Z=0.52(P=0.6)$} \\
\hline \multicolumn{6}{|c|}{ 1.10.2 Uterotonic at, or after, clamping } \\
\hline McDonald 1996 & $48 / 244$ & $58 / 239$ & - & $54.88 \%$ & $0.81[0.58,1.14]$ \\
\hline Subtotal $(95 \% \mathrm{Cl})$ & 244 & 239 & & $54.88 \%$ & $0.81[0.58,1.14]$ \\
\hline \multicolumn{6}{|c|}{ Total events: 48 (early clamping), 58 (late clamping) } \\
\hline \multicolumn{6}{|c|}{ Heterogeneity: Not applicable } \\
\hline \multicolumn{6}{|c|}{ Test for overall effect: $Z=1.22(P=0.22)$} \\
\hline Total $(95 \% \mathrm{Cl})$ & 480 & 483 & & $100 \%$ & $0.94[0.74,1.2]$ \\
\hline \multicolumn{6}{|c|}{ Total events: 100 (early clamping), 107 (late clamping) } \\
\hline \multicolumn{6}{|c|}{ Heterogeneity: $\operatorname{Tau}^{2}=0 ; \mathrm{Chi}^{2}=1.5, \mathrm{df}=1(\mathrm{P}=0.22) ; \mathrm{I}^{2}=33.32 \%$} \\
\hline \multicolumn{6}{|c|}{ Test for overall effect: $Z=0.5(P=0.62)$} \\
\hline \multicolumn{6}{|c|}{ Test for subgroup differences: $\mathrm{Chi}^{2}=1.5, \mathrm{df}=1(\mathrm{P}=0.22), \mathrm{I}^{2}=33.32 \%$} \\
\hline
\end{tabular}

Analysis 1.11. Comparison 1 Early versus late cord clamping, Outcome 11 Apgar score $<7$ at 5 mins.

\begin{tabular}{|c|c|c|c|c|c|}
\hline Study or subgroup & $\begin{array}{c}\text { early clamping } \\
n / N\end{array}$ & $\begin{array}{c}\text { late clamping } \\
\mathrm{n} / \mathrm{N} \\
\end{array}$ & $\begin{array}{c}\text { Risk Ratio } \\
\text { M-H, Fixed, } 95 \% \mathrm{CI}\end{array}$ & Weight & $\begin{array}{c}\text { Risk Ratio } \\
\text { M-H, Fixed, } 95 \% \mathrm{Cl}\end{array}$ \\
\hline \multicolumn{6}{|c|}{ 1.11.1 Uterotonic before clamping } \\
\hline McDonald 1996 & $5 / 236$ & $3 / 244$ & & $12.18 \%$ & $1.72[0.42,7.13]$ \\
\hline Subtotal $(95 \% \mathrm{Cl})$ & 236 & 244 & & $12.18 \%$ & $1.72[0.42,7.13]$ \\
\hline \multicolumn{6}{|c|}{ Total events: 5 (early clamping), 3 (late clamping) } \\
\hline \multicolumn{6}{|c|}{ Heterogeneity: Not applicable } \\
\hline \multicolumn{6}{|c|}{ Test for overall effect: $\mathrm{Z}=0.75(\mathrm{P}=0.45)$} \\
\hline \multicolumn{6}{|c|}{ 1.11.2 Uterotonic at, or after, clamping } \\
\hline McDonald 1996 & $8 / 244$ & $4 / 239$ & 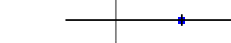 & $16.69 \%$ & $1.96[0.6,6.42]$ \\
\hline Philip 1973 & $0 / 28$ & $0 / 29$ & & & Not estimable \\
\hline Subtotal $(95 \% \mathrm{Cl})$ & 272 & 268 & & $16.69 \%$ & $1.96[0.6,6.42]$ \\
\hline \multicolumn{6}{|c|}{ Total events: 8 (early clamping), 4 (late clamping) } \\
\hline \multicolumn{6}{|c|}{ Heterogeneity: Not applicable } \\
\hline \multicolumn{6}{|c|}{ Test for overall effect: $Z=1.11(P=0.27)$} \\
\hline \multicolumn{6}{|c|}{ 1.11.3 Use of uterotonic not specified } \\
\hline Spears 1966 & $17 / 192$ & $17 / 187$ & & $71.13 \%$ & $0.97[0.51,1.85]$ \\
\hline Subtotal $(95 \% \mathrm{Cl})$ & 192 & 187 & & $71.13 \%$ & $0.97[0.51,1.85]$ \\
\hline \multicolumn{6}{|c|}{ Total events: 17 (early clamping), 17 (late clamping) } \\
\hline \multicolumn{6}{|c|}{ Heterogeneity: Not applicable } \\
\hline Test for overall effec & & & & & \\
\hline
\end{tabular}




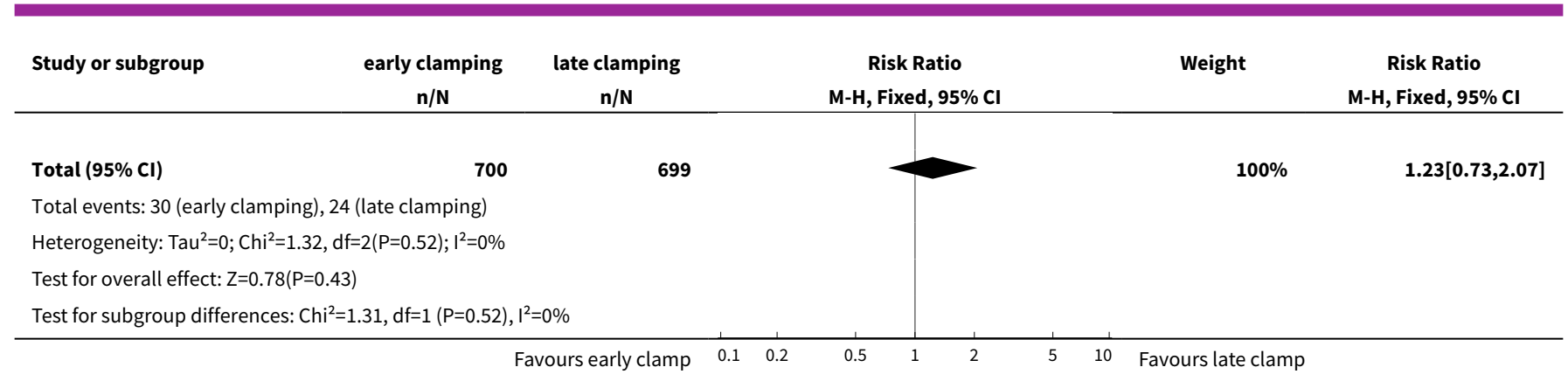

\section{Analysis 1.12. Comparison 1 Early versus late cord clamping, Outcome 12 Any admission to SCN or NICU.}

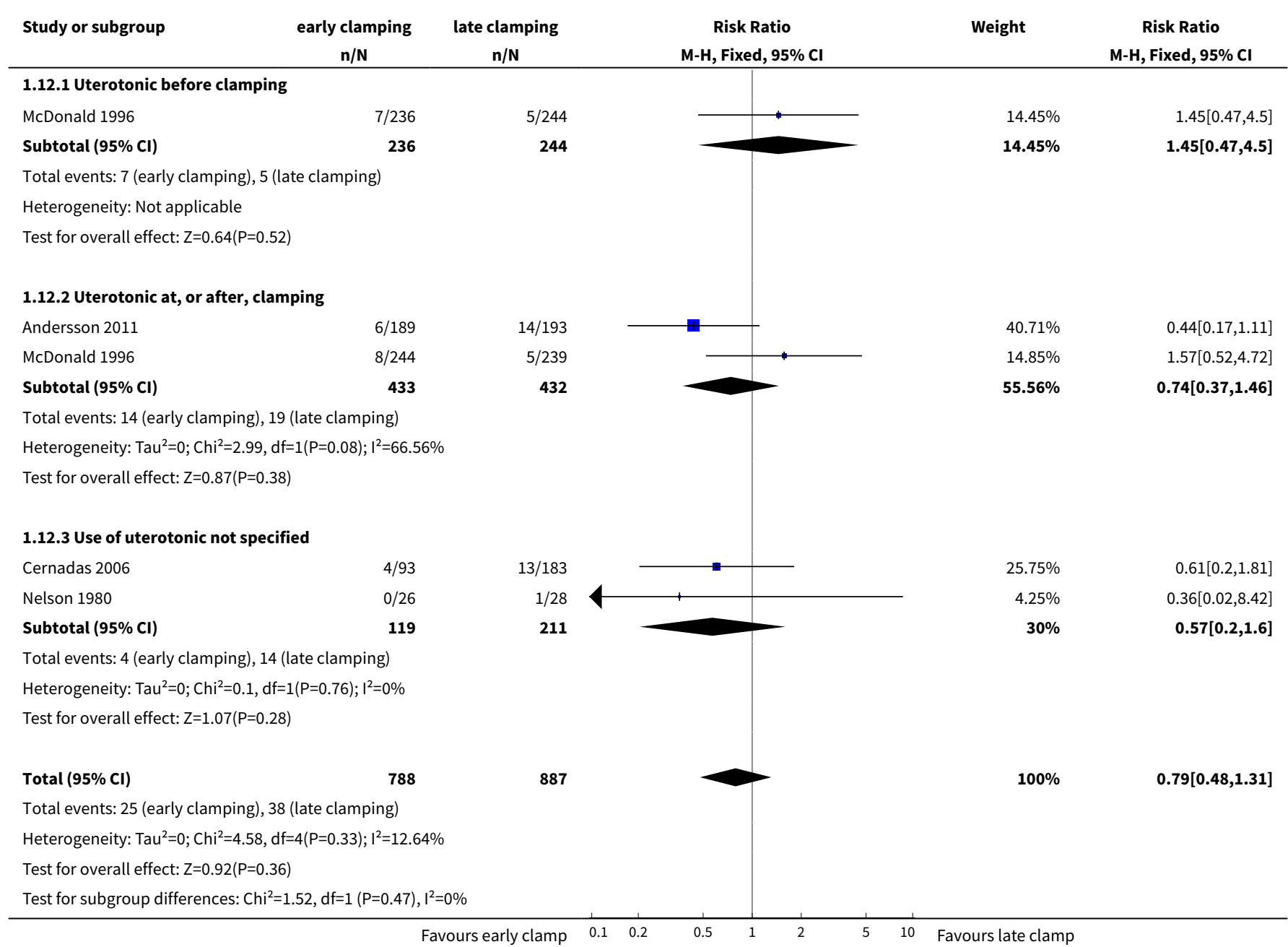

\section{Analysis 1.13. Comparison 1 Early versus late cord clamping, Outcome 13 Respiratory distress.}

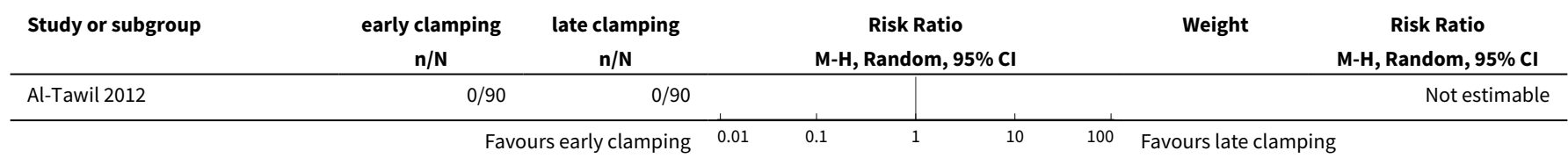




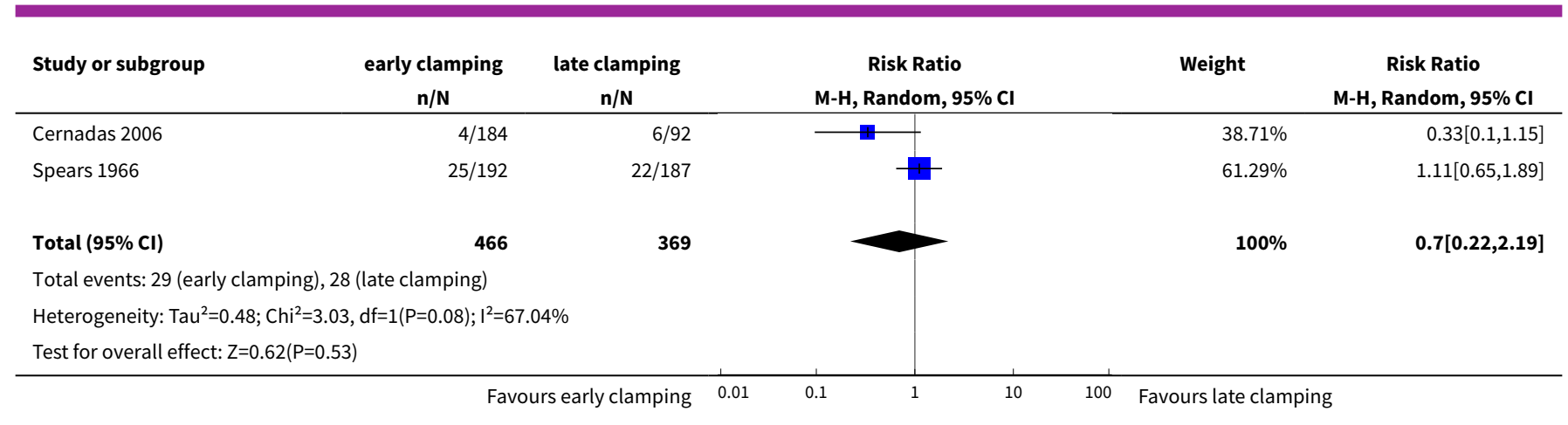

\section{Analysis 1.14. Comparison 1 Early versus late cord clamping, Outcome 14 Jaundice requiring phototherapy.}

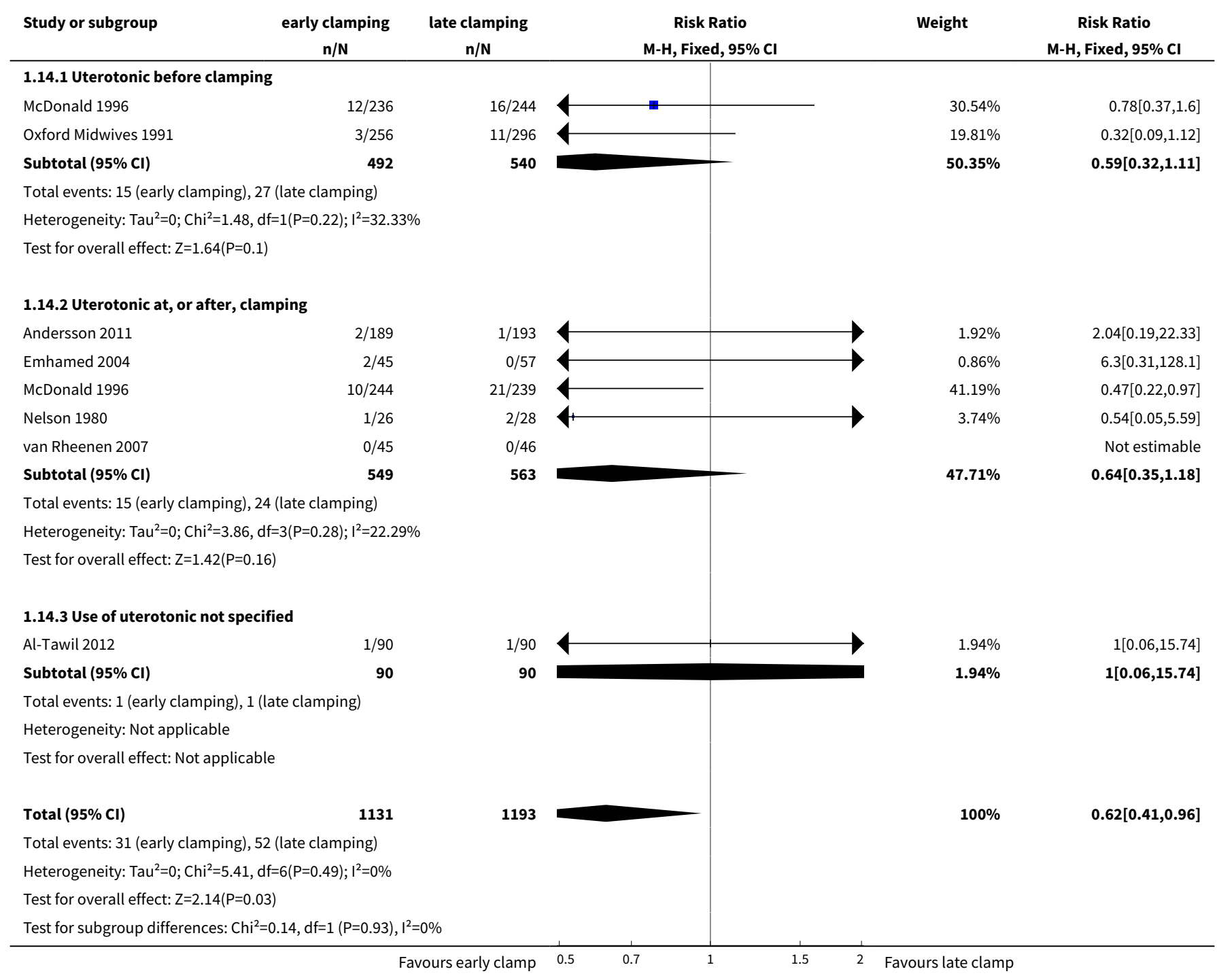


Analysis 1.15. Comparison 1 Early versus late cord clamping, Outcome 15 Clinical jaundice.

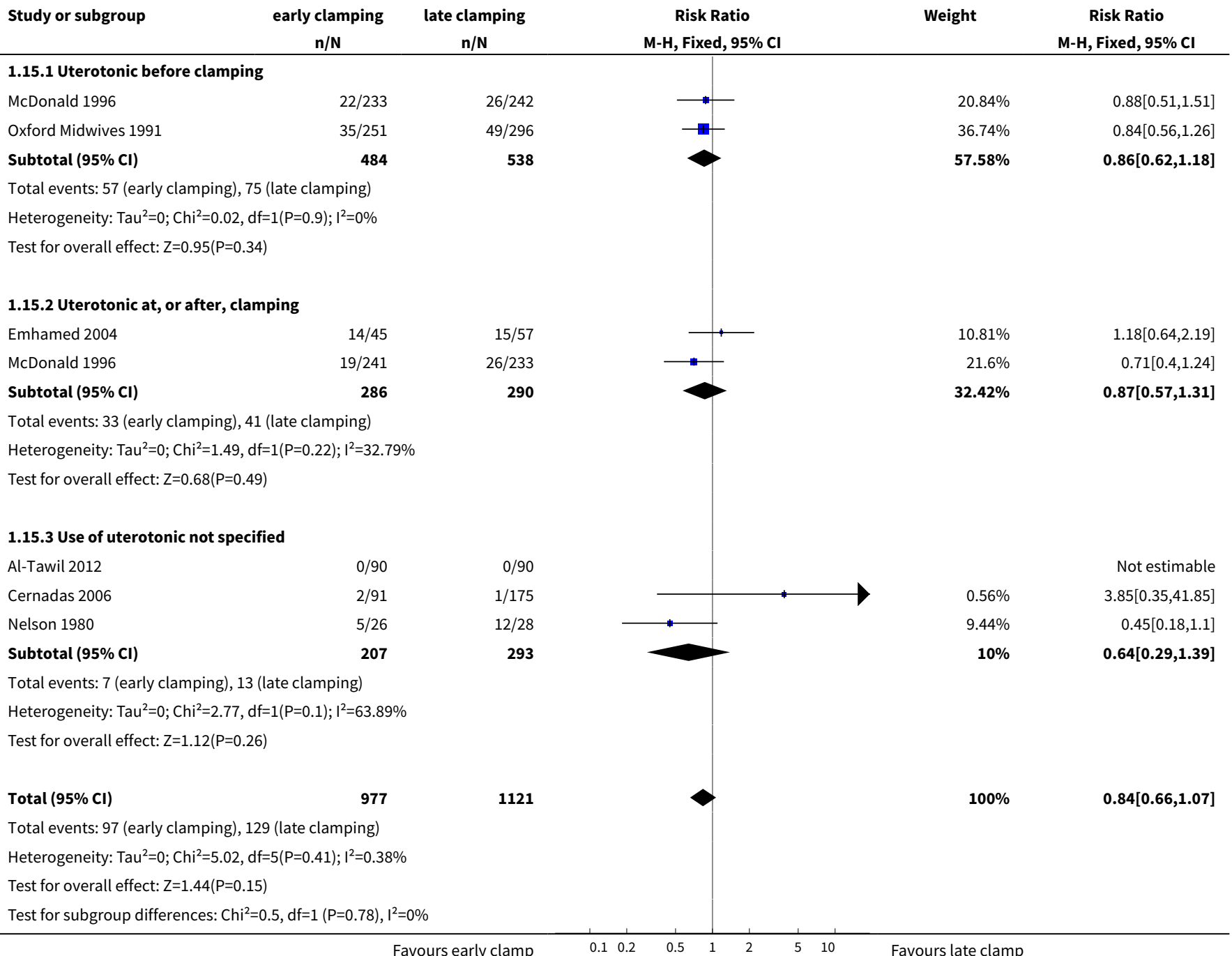

\section{Analysis 1.16. Comparison 1 Early versus late cord clamping, Outcome 16 Polycythaemia.}

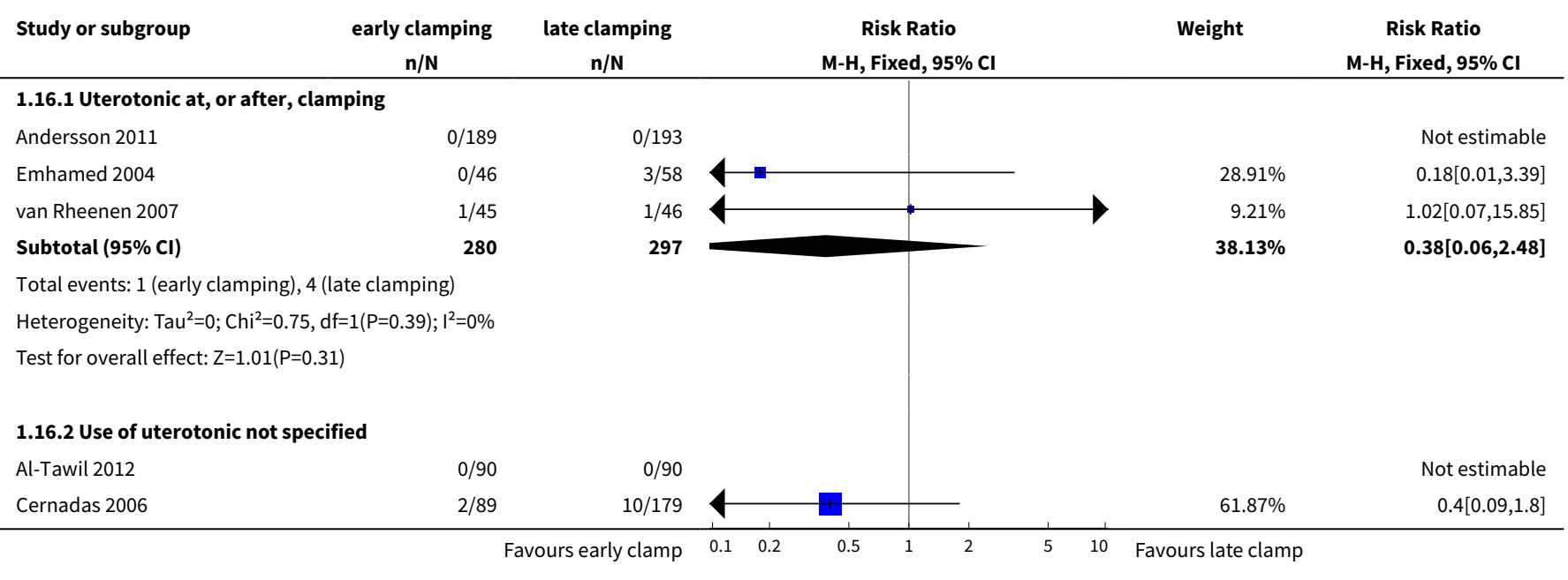




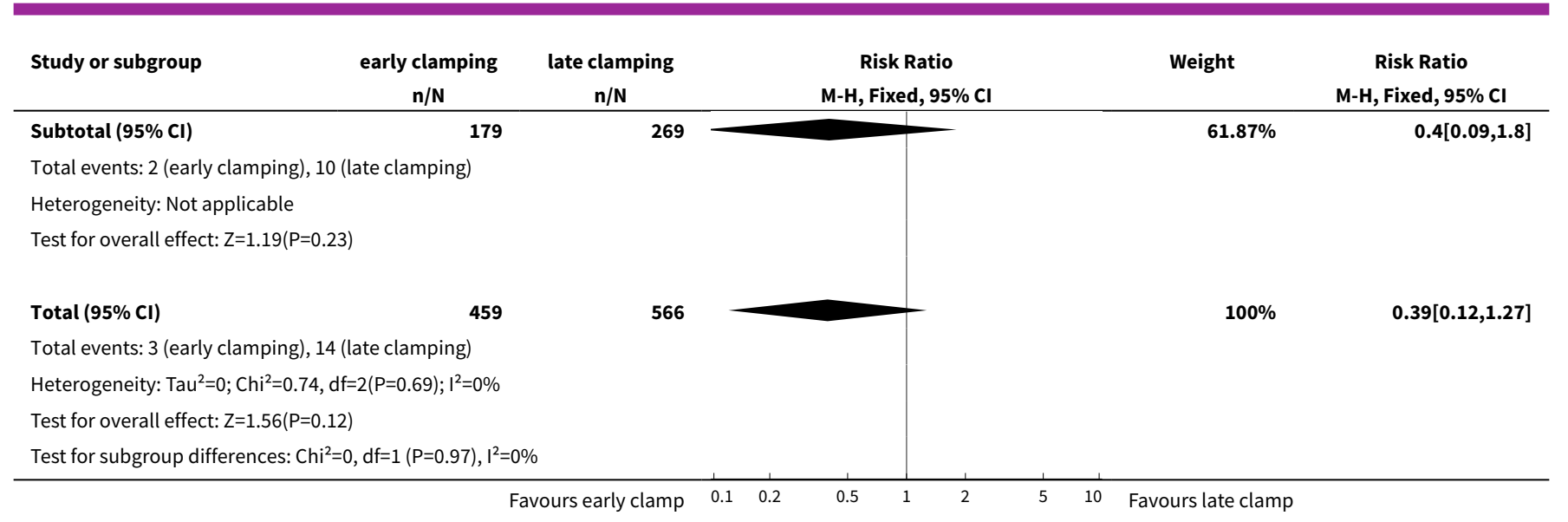

Analysis 1.17. Comparison 1 Early versus late cord clamping, Outcome 17 Cord haemoglobin (g/dL).

\begin{tabular}{|c|c|c|c|c|c|c|c|}
\hline \multirow[t]{2}{*}{ Study or subgroup } & \multicolumn{2}{|c|}{ early clamping } & \multicolumn{2}{|c|}{ late clamping } & \multirow{2}{*}{$\begin{array}{c}\text { Mean Difference } \\
\text { Fixed, } 95 \% \mathrm{Cl}\end{array}$} & \multirow[t]{2}{*}{ Weight } & \multirow{2}{*}{$\begin{array}{c}\text { Mean Difference } \\
\text { Fixed, } 95 \% \mathrm{Cl}\end{array}$} \\
\hline & $\mathbf{N}$ & Mean(SD) & $\mathbf{N}$ & $\operatorname{Mean}(S D)$ & & & \\
\hline \multicolumn{5}{|c|}{ 1.17.1 Uterotonic at, or after, clamping } & & & \\
\hline Andersson 2011 & 189 & $16.3(1.6)$ & 193 & $15.9(1.8)$ & & $56 \%$ & $0.4[0.06,0.74]$ \\
\hline Emhamed 2004 & 46 & $15.4(1.4)$ & 58 & $14.9(1.7)$ & 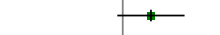 & $18.38 \%$ & $0.5[-0.1,1.1]$ \\
\hline Saigal 1972 & 15 & $16.8(1.7)$ & 30 & $15.6(2.1)$ & & $5 \%$ & $1.25[0.11,2.39]$ \\
\hline Subtotal $\star \star \star ~$ & 250 & & 281 & & & $79.38 \%$ & $0.48[0.19,0.76]$ \\
\hline \multicolumn{8}{|c|}{ Test for overall effect: $Z=3.26(P=0)$} \\
\hline \multicolumn{8}{|c|}{ 1.17.2 Use of uterotonic not specified } \\
\hline Geethanath 1997 & 48 & $16.1(2.2)$ & 59 & $15.5(2.3)$ & $\longrightarrow$ & $8.92 \%$ & $0.6[-0.26,1.46]$ \\
\hline Gupta 2002 & 29 & $13.9(1.5)$ & 29 & $14.1(1.4)$ & $\longrightarrow$ & $11.7 \%$ & $-0.2[-0.95,0.55]$ \\
\hline Subtotal $\star \star \star ~$ & 77 & & 88 & & & $20.62 \%$ & $0.15[-0.42,0.71]$ \\
\hline \multicolumn{8}{|c|}{ Heterogeneity: Tau $^{2}=0 ; \mathrm{Chi}^{2}=1.91, \mathrm{df}=1(\mathrm{P}=0.17) ; \mathrm{I}^{2}=47.55 \%$} \\
\hline \multicolumn{8}{|c|}{ Test for overall effect: $Z=0.51(P=0.61)$} \\
\hline 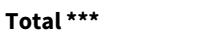 & 327 & & 369 & & $>$ & $100 \%$ & $0.41[0.15,0.66]$ \\
\hline \multicolumn{8}{|c|}{ Heterogeneity: $\mathrm{Tau}^{2}=0 ; \mathrm{Chi}^{2}=4.92, \mathrm{df}=4(\mathrm{P}=0.3) ; \mathrm{I}^{2}=18.71 \%$} \\
\hline \multicolumn{8}{|c|}{ Test for overall effect: $Z=3.13(P=0)$} \\
\hline \multicolumn{8}{|c|}{ Test for subgroup differences: $\mathrm{Chi}^{2}=1.05, \mathrm{df}=1(\mathrm{P}=0.3), \mathrm{I}^{2}=5.1 \%$} \\
\hline
\end{tabular}

\section{Analysis 1.18. Comparison 1 Early versus late cord clamping, Outcome 18 Newborn haemoglobin (g/dL).}

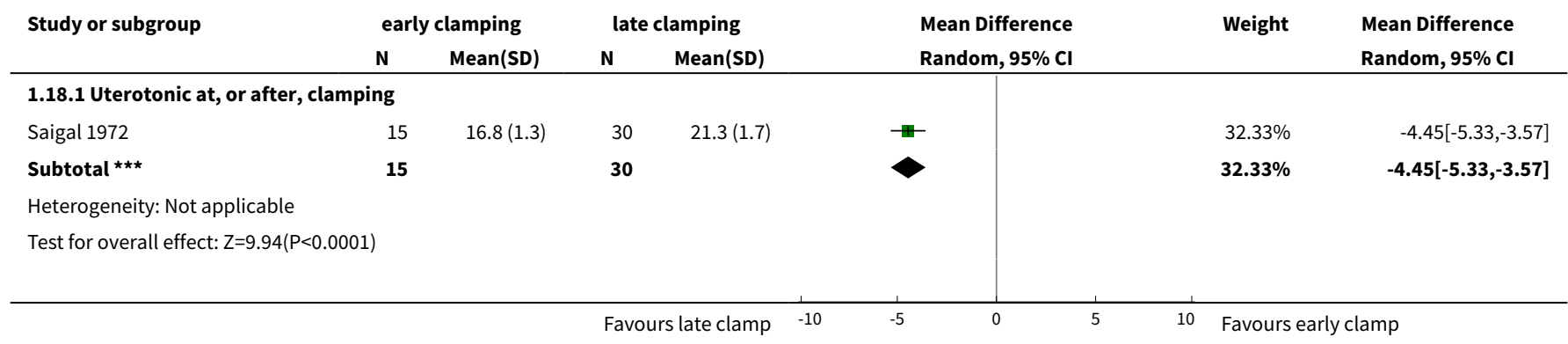




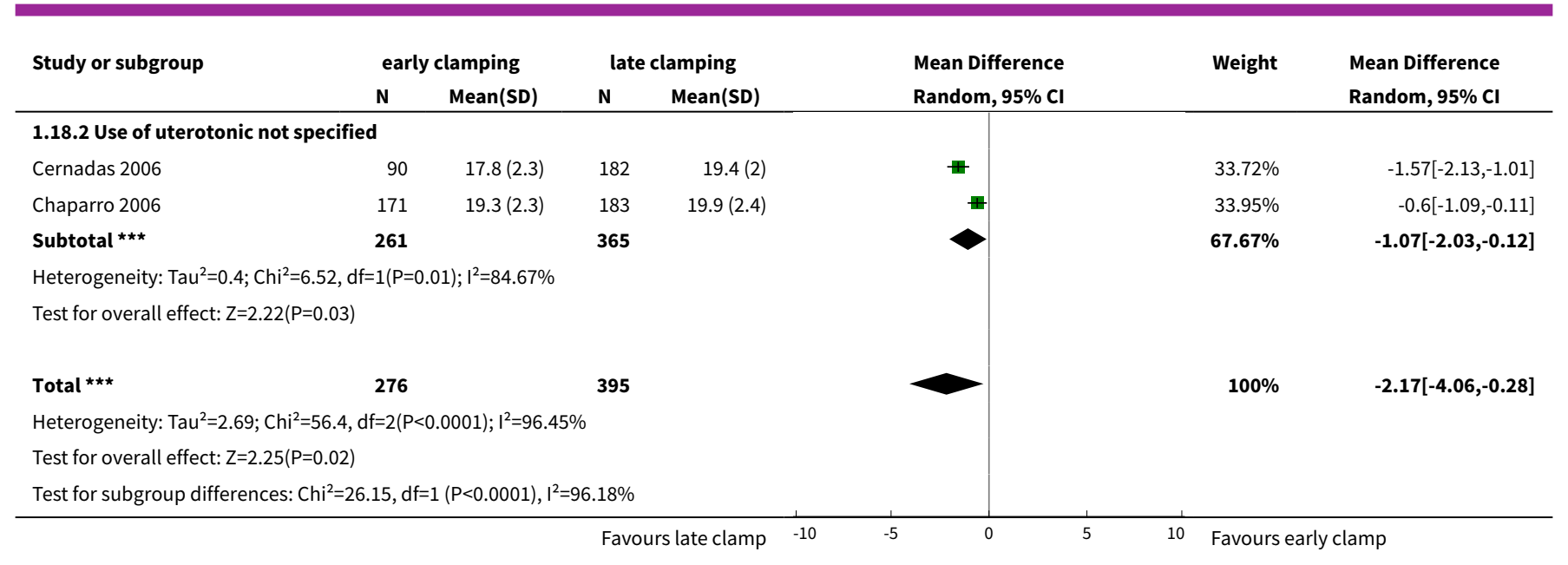

Analysis 1.19. Comparison 1 Early versus late cord clamping, Outcome 19 Infant haemoglobin at 24-48 hours (g/dL).

\begin{tabular}{|c|c|c|c|c|c|c|c|}
\hline \multirow[t]{2}{*}{ Study or subgroup } & \multicolumn{2}{|c|}{ early clamping } & \multicolumn{2}{|c|}{ late clamping } & \multirow{2}{*}{$\begin{array}{c}\text { Mean Difference } \\
\text { Fixed, } 95 \% \mathrm{Cl}\end{array}$} & \multirow[t]{2}{*}{ Weight } & \multirow{2}{*}{$\begin{array}{c}\text { Mean Difference } \\
\text { Fixed, } 95 \% \mathrm{Cl}\end{array}$} \\
\hline & $\mathbf{N}$ & $\operatorname{Mean}(S D)$ & $\mathbf{N}$ & Mean(SD) & & & \\
\hline \multicolumn{8}{|c|}{ 1.19.1 Uterotonic at, or after, clamping } \\
\hline Andersson 2011 & 160 & $17.5(1.9)$ & 162 & $18.9(1.7)$ & + & $52.68 \%$ & $-1.4[-1.79,-1.01]$ \\
\hline Emhamed 2004 & 46 & $17.1(1.9)$ & 58 & $18.5(2.1)$ & + & $13.77 \%$ & $-1.4[-2.17,-0.63]$ \\
\hline Subtotal $* \star \star$ & 206 & & 220 & & $\diamond$ & $66.45 \%$ & $-1.4[-1.75,-1.05]$ \\
\hline \multicolumn{8}{|c|}{ Heterogeneity: Tau $^{2}=0 ; \mathrm{Chi}^{2}=0, \mathrm{df}=1(\mathrm{P}=1) ; \mathrm{I}^{2}=0 \%$} \\
\hline \multicolumn{8}{|c|}{ 1.19.2 Use of uterotonic not specified } \\
\hline Al-Tawil 2012 & 90 & $16.8(2.9)$ & 90 & $19.6(3.8)$ & $\rightarrow$ & $8.38 \%$ & $-2.8[-3.79,-1.81]$ \\
\hline Cernadas 2006 & 89 & $17(2.3)$ & 189 & $18.3(2.2)$ & - & $25.16 \%$ & $-1.31[-1.88,-0.74]$ \\
\hline Subtotal ${ }^{\star \star \star}$ & 179 & & 279 & & $\diamond$ & $33.55 \%$ & $-1.68[-2.18,-1.19]$ \\
\hline \multicolumn{8}{|c|}{ Heterogeneity: $\mathrm{Tau}^{2}=0 ; \mathrm{Chi}^{2}=6.56, \mathrm{df}=1(\mathrm{P}=0.01) ; \mathrm{I}^{2}=84.75 \%$} \\
\hline \multicolumn{8}{|c|}{ Test for overall effect: $Z=6.68(P<0.0001)$} \\
\hline Total $\star \star \star ~$ & 385 & & 499 & & $\checkmark$ & $100 \%$ & $-1.49[-1.78,-1.21]$ \\
\hline \multicolumn{8}{|c|}{ Heterogeneity: $\mathrm{Tau}^{2}=0 ; \mathrm{Chi}^{2}=7.39, \mathrm{df}=3(\mathrm{P}=0.06) ; \mathrm{I}^{2}=59.43 \%$} \\
\hline \multicolumn{8}{|c|}{ Test for overall effect: $Z=10.25(P<0.0001)$} \\
\hline Test for subgroup dif & $83, \mathrm{df}=$ & $P=0.36), I^{2}=0 \%$ & & & & & \\
\hline
\end{tabular}

Analysis 1.20. Comparison 1 Early versus late cord clamping, Outcome 20 Infant haemoglobin at 3-6 months (g/dL).

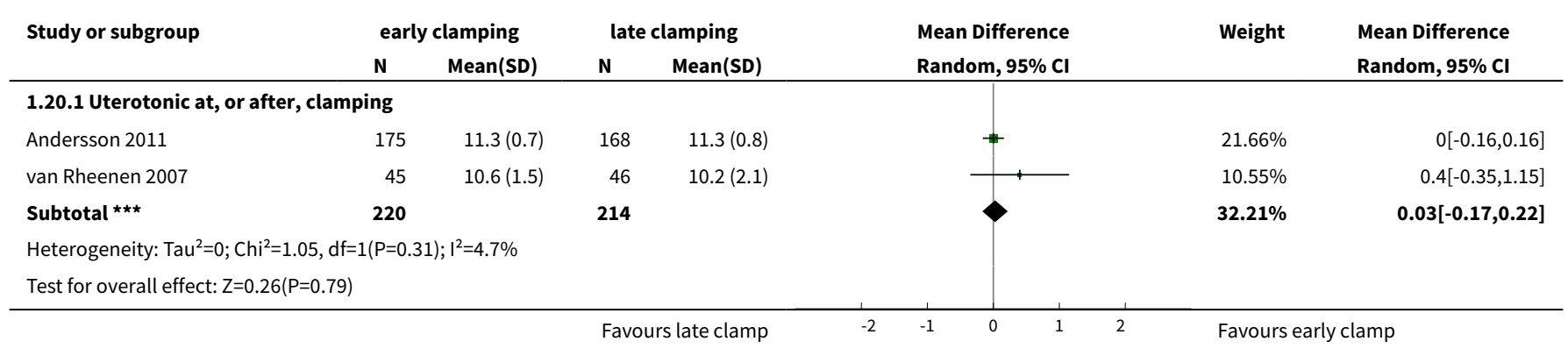




\begin{tabular}{|c|c|c|c|c|c|c|c|}
\hline \multirow[t]{2}{*}{ Study or subgroup } & \multicolumn{2}{|c|}{ early clamping } & \multicolumn{2}{|c|}{ late clamping } & \multirow{2}{*}{$\begin{array}{l}\text { Mean Difference } \\
\text { Random, } 95 \% \mathrm{Cl}\end{array}$} & \multirow[t]{2}{*}{ Weight } & \multirow{2}{*}{$\begin{array}{l}\text { Mean Difference } \\
\text { Random, } 95 \% \mathrm{Cl}\end{array}$} \\
\hline & $\mathbf{N}$ & Mean(SD) & $\mathbf{N}$ & Mean(SD) & & & \\
\hline \multicolumn{8}{|c|}{ 1.20.2 Use of uterotonic not specified } \\
\hline Al-Tawil 2012 & 78 & $11.6(0.8)$ & 82 & $12(1.1)$ & 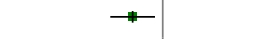 & $19.28 \%$ & $-0.4[-0.7,-0.1]$ \\
\hline Chaparro 2006 & 171 & $12.7(0.9)$ & 185 & $12.7(1.1)$ & - & $20.92 \%$ & $0[-0.21,0.21]$ \\
\hline Geethanath 1997 & 48 & $8.9(1.6)$ & 59 & $8.3(2.1)$ & 1 & $11.29 \%$ & $0.6[-0.1,1.3]$ \\
\hline Gupta 2002 & 29 & $8.8(0.8)$ & 29 & $9.9(0.9)$ & $\longrightarrow$ & $16.31 \%$ & $-1.1[-1.54,-0.66]$ \\
\hline Subtotal $\star \star \star$ & 326 & & 355 & & & $67.79 \%$ & $-0.26[-0.79,0.26]$ \\
\hline \multicolumn{8}{|c|}{ Heterogeneity: $\operatorname{Tau}^{2}=0.24 ; \mathrm{Chi}^{2}=26.44, \mathrm{df}=3(\mathrm{P}<0.0001) ; \mathrm{I}^{2}=88.65 \%$} \\
\hline \multicolumn{8}{|c|}{ Test for overall effect: $Z=0.98(P=0.33)$} \\
\hline Total $\star \star \star$ & 546 & & 569 & & & $100 \%$ & $-0.15[-0.48,0.19]$ \\
\hline \multicolumn{8}{|c|}{ Heterogeneity: $\mathrm{Tau}^{2}=0.13 ; \mathrm{Chi}^{2}=31.86, \mathrm{df}=5(\mathrm{P}<0.0001) ; \mathrm{I}^{2}=84.31 \%$} \\
\hline \multicolumn{8}{|c|}{ Test for overall effect: $\mathrm{Z}=0.87(\mathrm{P}=0.39)$} \\
\hline \multicolumn{8}{|c|}{ Test for subgroup differences: $\mathrm{Chi}^{2}=1.02, \mathrm{df}=1(\mathrm{P}=0.31), \mathrm{I}^{2}=1.89 \%$} \\
\hline
\end{tabular}

\section{Analysis 1.21. Comparison 1 Early versus late cord clamping, Outcome 21 Low infant haemoglobin at 3-6 months.}

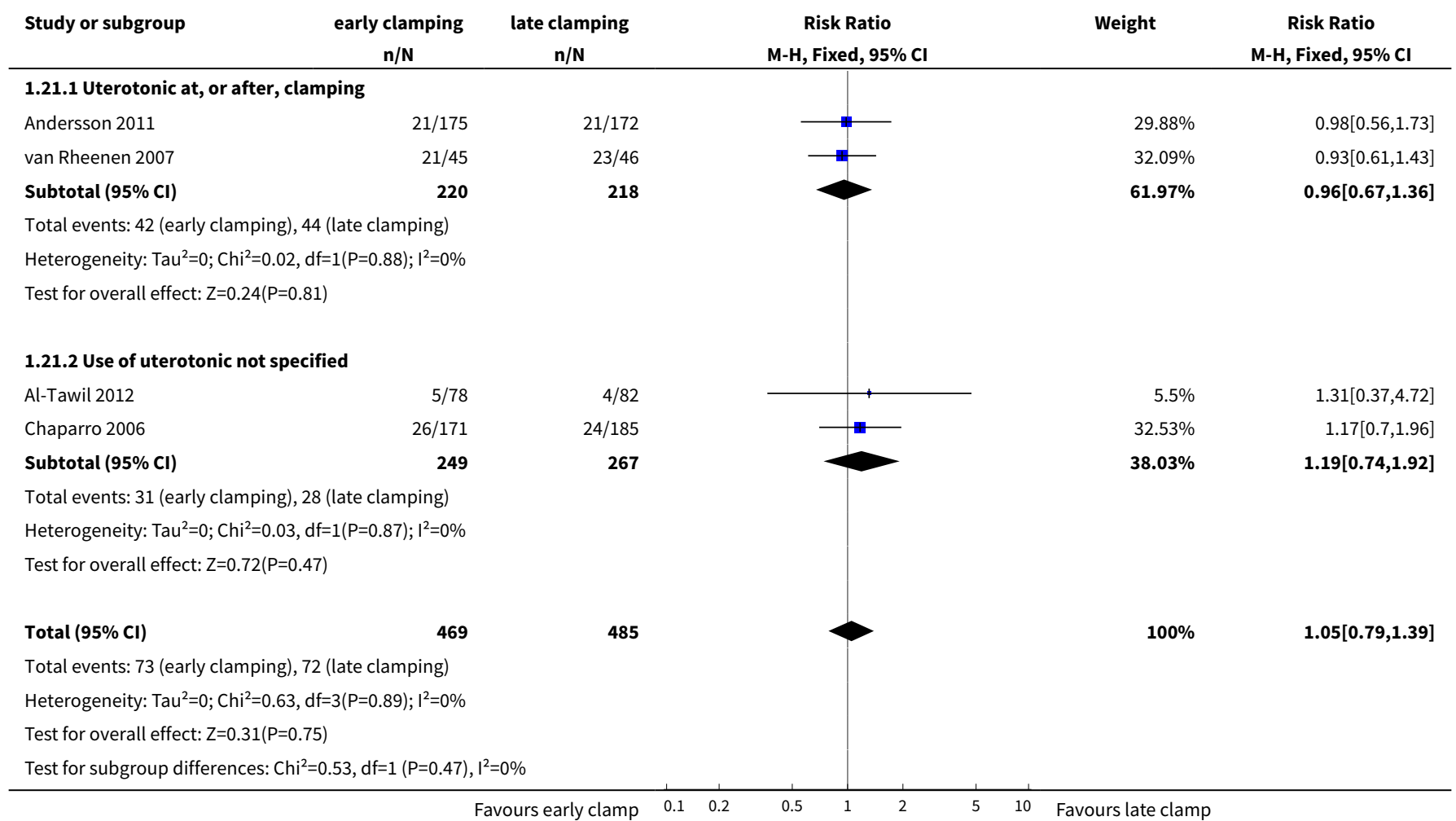


Analysis 1.22. Comparison 1 Early versus late cord clamping, Outcome 22 Infant haematocrit (\%).

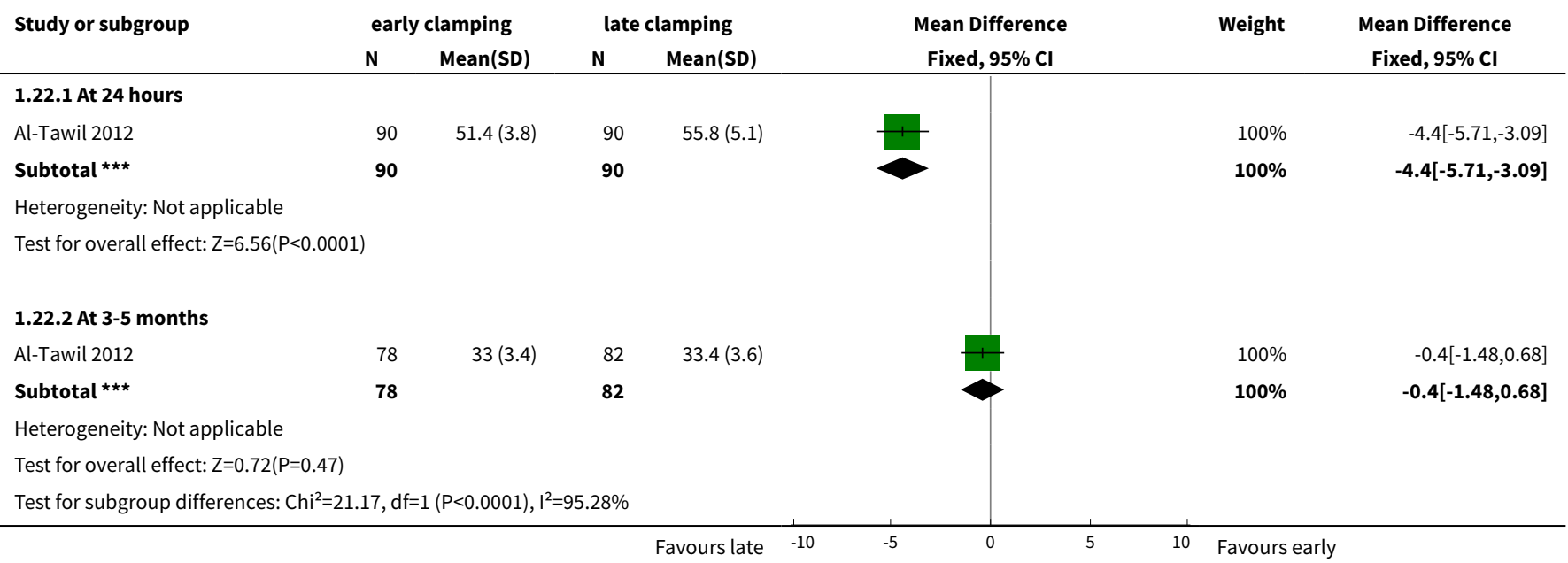

Analysis 1.23. Comparison 1 Early versus late cord clamping, Outcome 23 Low infant haematocrit ( $<45 \%$ at 6 hours).

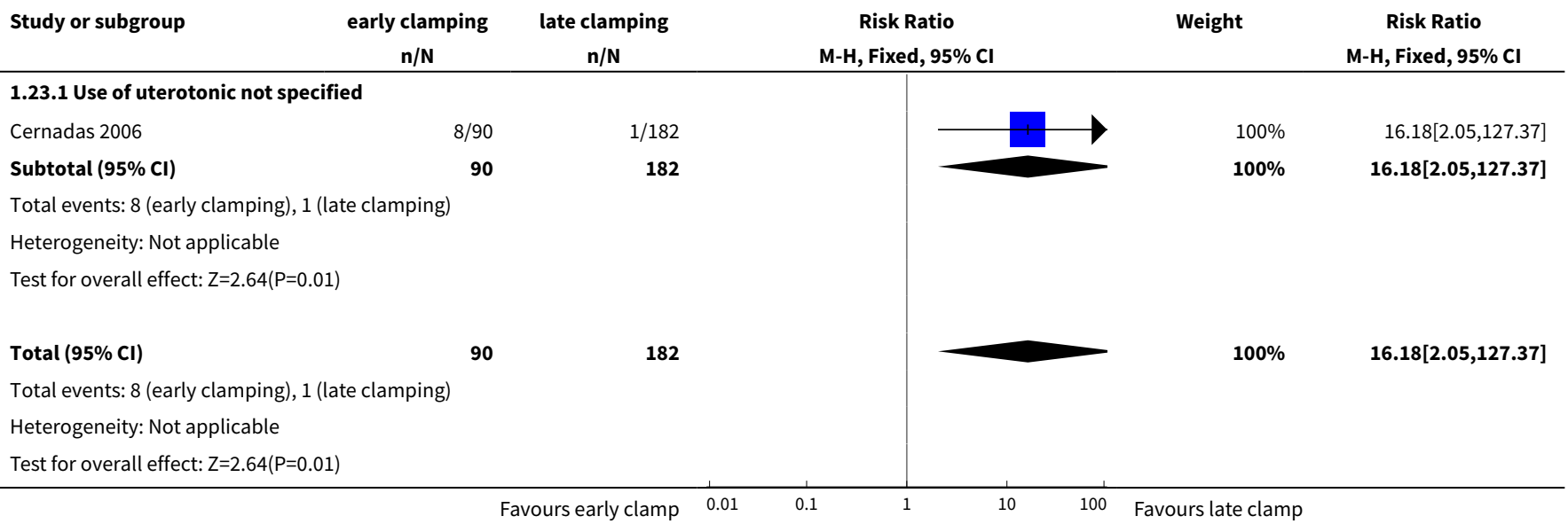

Analysis 1.24. Comparison 1 Early versus late cord clamping, Outcome 24 Low infant haematocrit ( $<45 \%$ at $24-48$ hours).

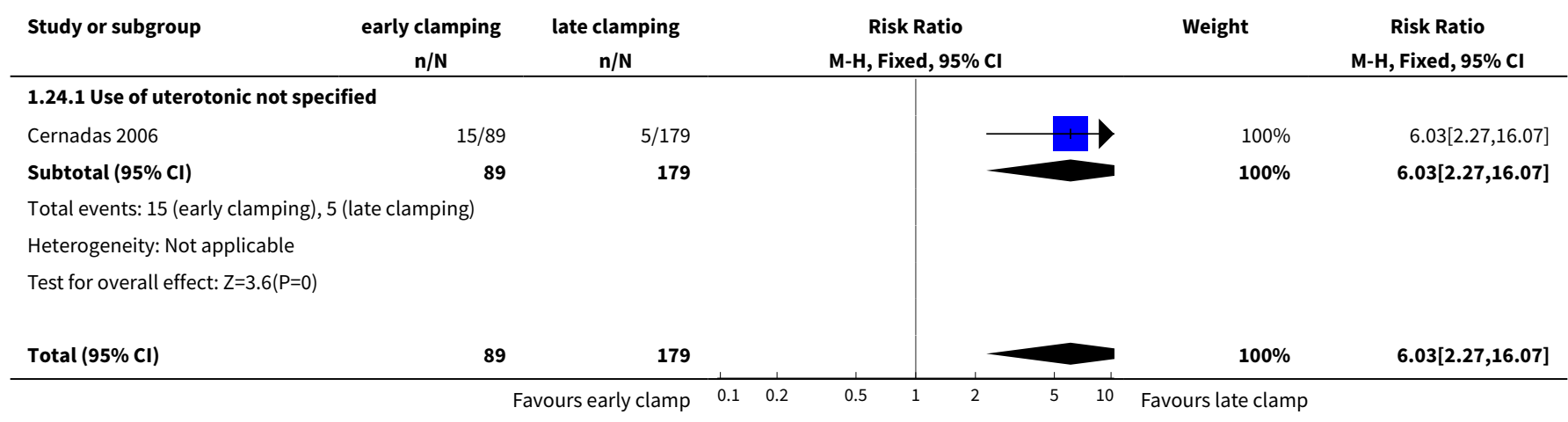




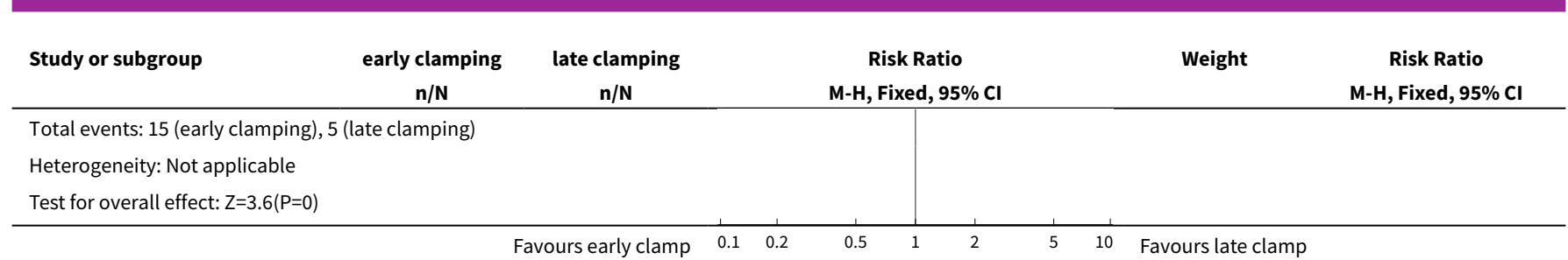

\section{Analysis 1.25. Comparison 1 Early versus late cord clamping, Outcome 25 Infant iron deficiency at 3-6 months.}

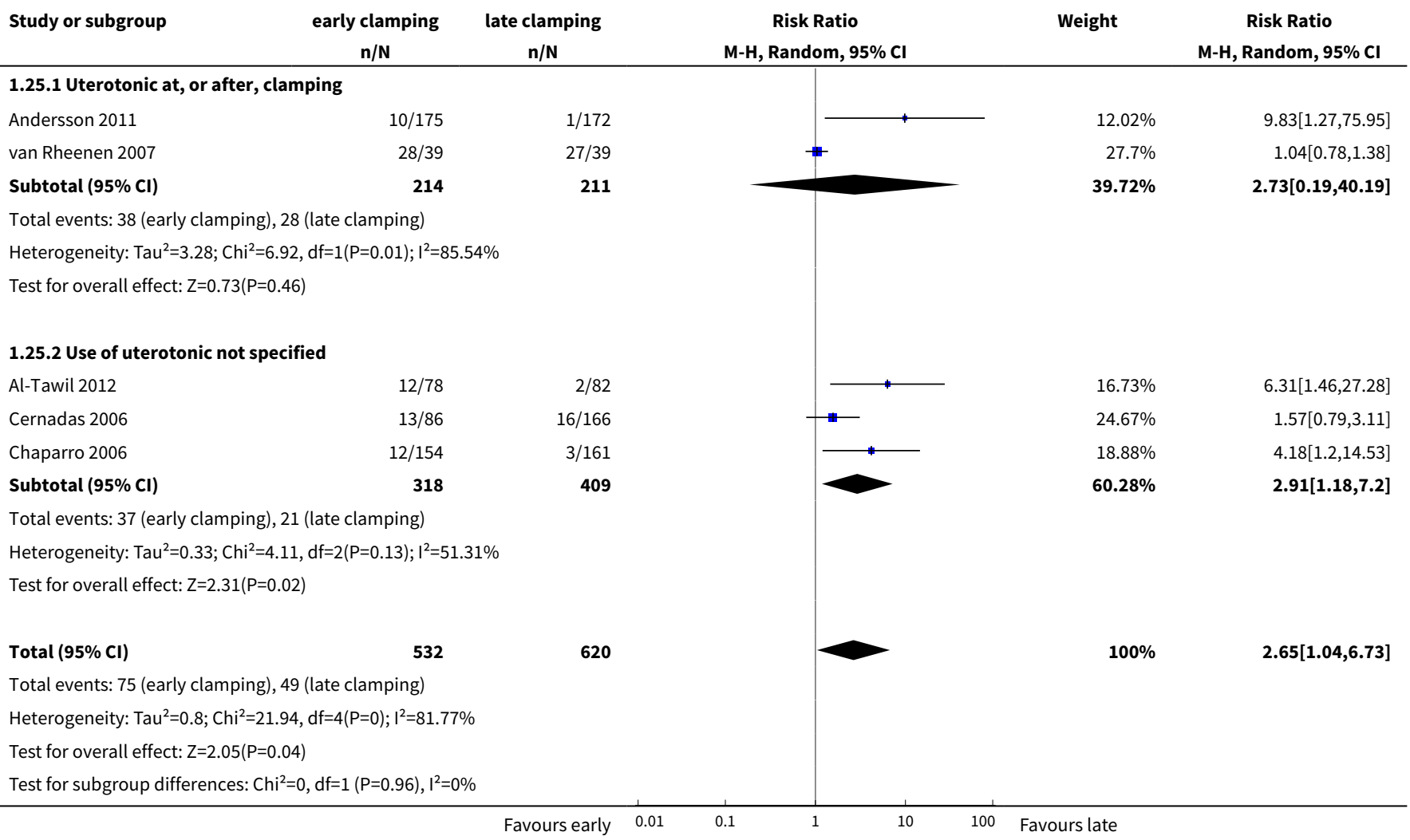

Analysis 1.26. Comparison 1 Early versus late cord clamping, Outcome 26 Birthweight (g).

\begin{tabular}{|c|c|c|c|c|c|c|c|}
\hline \multirow{3}{*}{$\begin{array}{l}\text { Study or subgroup } \\
\text { Al-Tawil } 2012\end{array}$} & \multicolumn{2}{|c|}{ early clamping } & \multicolumn{2}{|c|}{ late clamping } & \multirow{2}{*}{$\begin{array}{l}\text { Mean Difference } \\
\text { Random, } 95 \% \mathrm{Cl}\end{array}$} & \multirow[t]{2}{*}{ Weight } & \multirow{2}{*}{$\begin{array}{l}\text { Mean Difference } \\
\text { Random, 95\% Cl }\end{array}$} \\
\hline & $\mathbf{N}$ & Mean(SD) & $\mathbf{N}$ & Mean(SD) & & & \\
\hline & 90 & $\begin{array}{l}3110.6 \\
(540.8)\end{array}$ & 90 & $\begin{array}{r}3348 \\
(390.8)\end{array}$ & & $8.14 \%$ & $-237.4[-375.25,-99.55]$ \\
\hline Andersson 2011 & 189 & $3533(486)$ & 193 & $3629(460)$ & 1 & $10.93 \%$ & $-96[-190.93,-1.07]$ \\
\hline Cernadas 2006 & 93 & 3390 (395) & 183 & $3422(372)$ & 1 & $10.8 \%$ & $-32[-128.69,64.69]$ \\
\hline Chaparro 2006 & 171 & $3196(362)$ & 187 & 3318 (369) & & $12.31 \%$ & $-122[-197.77,-46.23]$ \\
\hline Emhamed 2004 & 46 & $3428(424)$ & 58 & $3390(421)$ & & $6.79 \%$ & $38[-125.56,201.56]$ \\
\hline Gupta 2002 & 29 & $2707(417)$ & 29 & $2744(408)$ & & $4.88 \%$ & $-37[-249.33,175.33]$ \\
\hline Jahazi 2008 & 30 & 3009 (573) & 34 & $3272(329)$ & & $4.28 \%$ & $-263[-495.96,-30.04]$ \\
\hline McDonald 1996 & 480 & 3374 (493) & 483 & $3416(495)$ & 1 & $13.26 \%$ & $-42[-104.4,20.4]$ \\
\hline Nelson 1980 & 26 & 3489 (453) & 28 & 3437 (439) & & $4.14 \%$ & $52[-186.24,290.24]$ \\
\hline
\end{tabular}




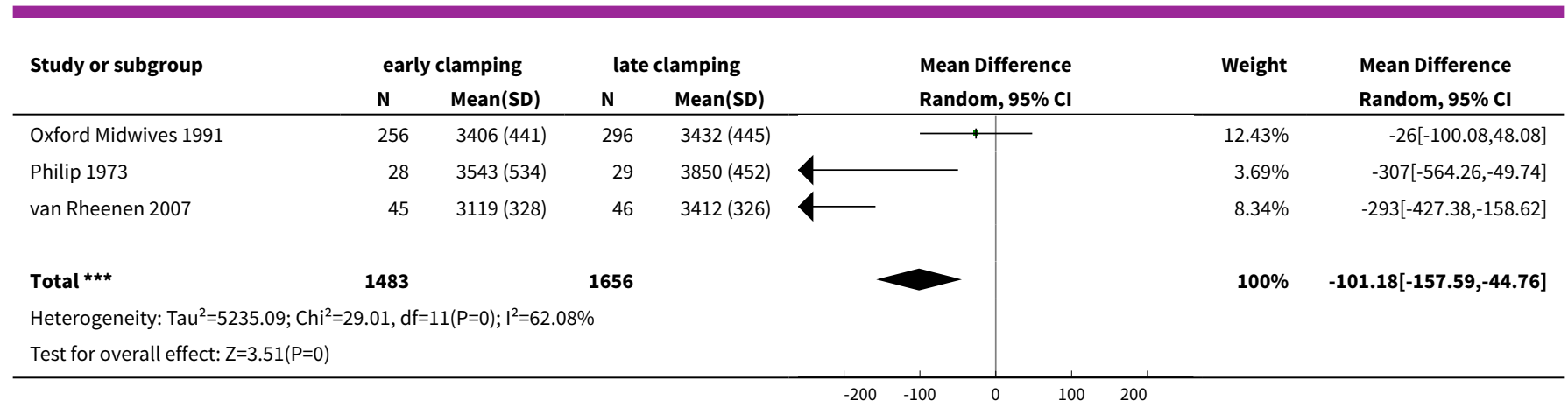

Analysis 1.27. Comparison 1 Early versus late cord clamping, Outcome 27 Not breastfeeding on discharge (or later).

\begin{tabular}{|c|c|c|c|c|c|}
\hline Study or subgroup & $\begin{array}{c}\text { early clamping } \\
n / N\end{array}$ & $\begin{array}{c}\text { late clamping } \\
\mathrm{n} / \mathrm{N}\end{array}$ & $\begin{array}{c}\text { Risk Ratio } \\
\text { M-H, Fixed, } 95 \% \mathrm{Cl}\end{array}$ & Weight & $\begin{array}{c}\text { Risk Ratio } \\
\text { M-H, Fixed, } 95 \% \mathrm{Cl} \\
\end{array}$ \\
\hline \multicolumn{6}{|l|}{ 1.27.1 At discharge } \\
\hline Jahazi 2008 & $0 / 30$ & $0 / 34$ & & & Not estimable \\
\hline McDonald 1996 & $48 / 480$ & $49 / 483$ & $\rightarrow$ & $36.9 \%$ & $0.99[0.68,1.44]$ \\
\hline Nelson 1980 & $2 / 26$ & $1 / 28$ & & $0.73 \%$ & $2.15[0.21,22.37]$ \\
\hline Oxford Midwives 1991 & $90 / 256$ & $89 / 296$ & E & $62.37 \%$ & $1.17[0.92,1.49]$ \\
\hline Subtotal $(95 \% \mathrm{Cl})$ & 792 & 841 & & $100 \%$ & $1.11[0.9,1.36]$ \\
\hline \multicolumn{6}{|c|}{ Total events: 140 (early clamping), 139 (late clamping) } \\
\hline \multicolumn{6}{|c|}{ Heterogeneity: Tau $^{2}=0 ; \mathrm{Chi}^{2}=0.87, \mathrm{df}=2(\mathrm{P}=0.65) ; \mathrm{I}^{2}=0 \%$} \\
\hline \multicolumn{6}{|c|}{ Test for overall effect: $Z=0.99(P=0.32)$} \\
\hline \multicolumn{6}{|l|}{ 1.27.2 At 1 month } \\
\hline Cernadas 2006 & $82 / 90$ & $148 / 178$ & & $100 \%$ & $1.1[1,1.2]$ \\
\hline Subtotal $(95 \% \mathrm{Cl})$ & 90 & 178 & 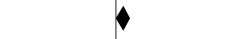 & $100 \%$ & $1.1[1,1.2]$ \\
\hline \multicolumn{6}{|c|}{ Total events: 82 (early clamping), 148 (late clamping) } \\
\hline \multicolumn{6}{|c|}{ Heterogeneity: Not applicable } \\
\hline \multicolumn{6}{|c|}{ Test for overall effect: $Z=1.94(P=0.05)$} \\
\hline \multicolumn{6}{|l|}{ 1.27.3 At 2 months } \\
\hline van Rheenen 2007 & $0 / 41$ & $2 / 43$ & & $100 \%$ & $0.21[0.01,4.24]$ \\
\hline Subtotal $(95 \% \mathrm{Cl})$ & 41 & 43 & & $100 \%$ & $0.21[0.01,4.24]$ \\
\hline \multicolumn{6}{|c|}{ Total events: 0 (early clamping), 2 (late clamping) } \\
\hline \multicolumn{6}{|c|}{ Heterogeneity: Not applicable } \\
\hline \multicolumn{6}{|c|}{ Test for overall effect: $Z=1.02(P=0.31)$} \\
\hline \multicolumn{6}{|l|}{ 1.27.4 At 3 months } \\
\hline Geethanath 1997 & $4 / 40$ & $3 / 46$ & - & $35.82 \%$ & $1.53[0.36,6.44]$ \\
\hline Gupta 2002 & $3 / 29$ & $5 / 29$ & & $64.18 \%$ & $0.6[0.16,2.28]$ \\
\hline Subtotal (95\% Cl) & 69 & 75 & & $100 \%$ & $0.93[0.36,2.42]$ \\
\hline \multicolumn{6}{|c|}{ Total events: 7 (early clamping), 8 (late clamping) } \\
\hline \multicolumn{6}{|c|}{ Heterogeneity: Tau $^{2}=0 ; \mathrm{Chi}^{2}=0.88, \mathrm{df}=1(\mathrm{P}=0.35) ; \mathrm{I}^{2}=0 \%$} \\
\hline \multicolumn{6}{|c|}{ Test for overall effect: $Z=0.14(P=0.89)$} \\
\hline \multicolumn{6}{|l|}{ 1.27.5 At 4 months } \\
\hline Chaparro 2006 & $87 / 147$ & $98 / 166$ & & $75.42 \%$ & $1[0.83,1.21]$ \\
\hline van Rheenen 2007 & $15 / 39$ & $30 / 39$ & $\square$ & $24.58 \%$ & $0.5[0.32,0.77]$ \\
\hline Subtotal (95\% Cl) & 186 & 205 & 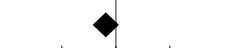 & $100 \%$ & $0.88[0.74,1.04]$ \\
\hline
\end{tabular}




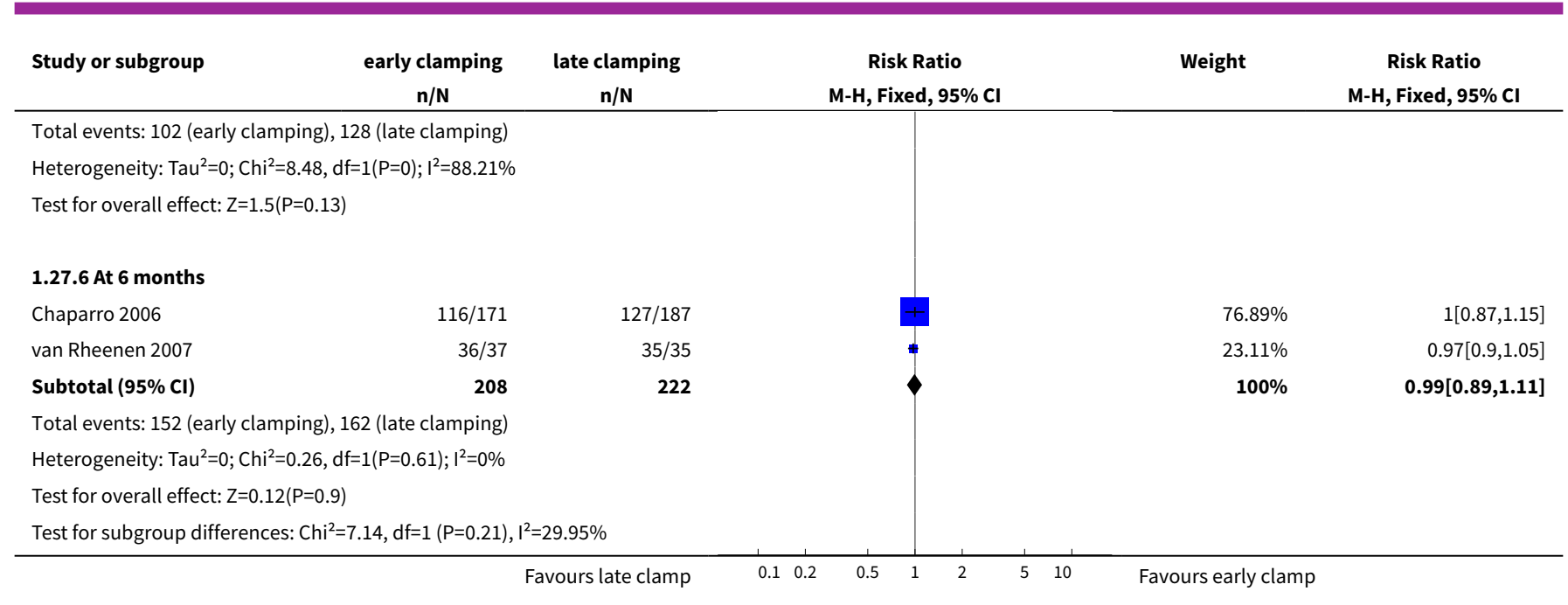

\section{Analysis 1.28. Comparison 1 Early versus late cord clamping, Outcome 28 Neurodevelopment at 4 months.}

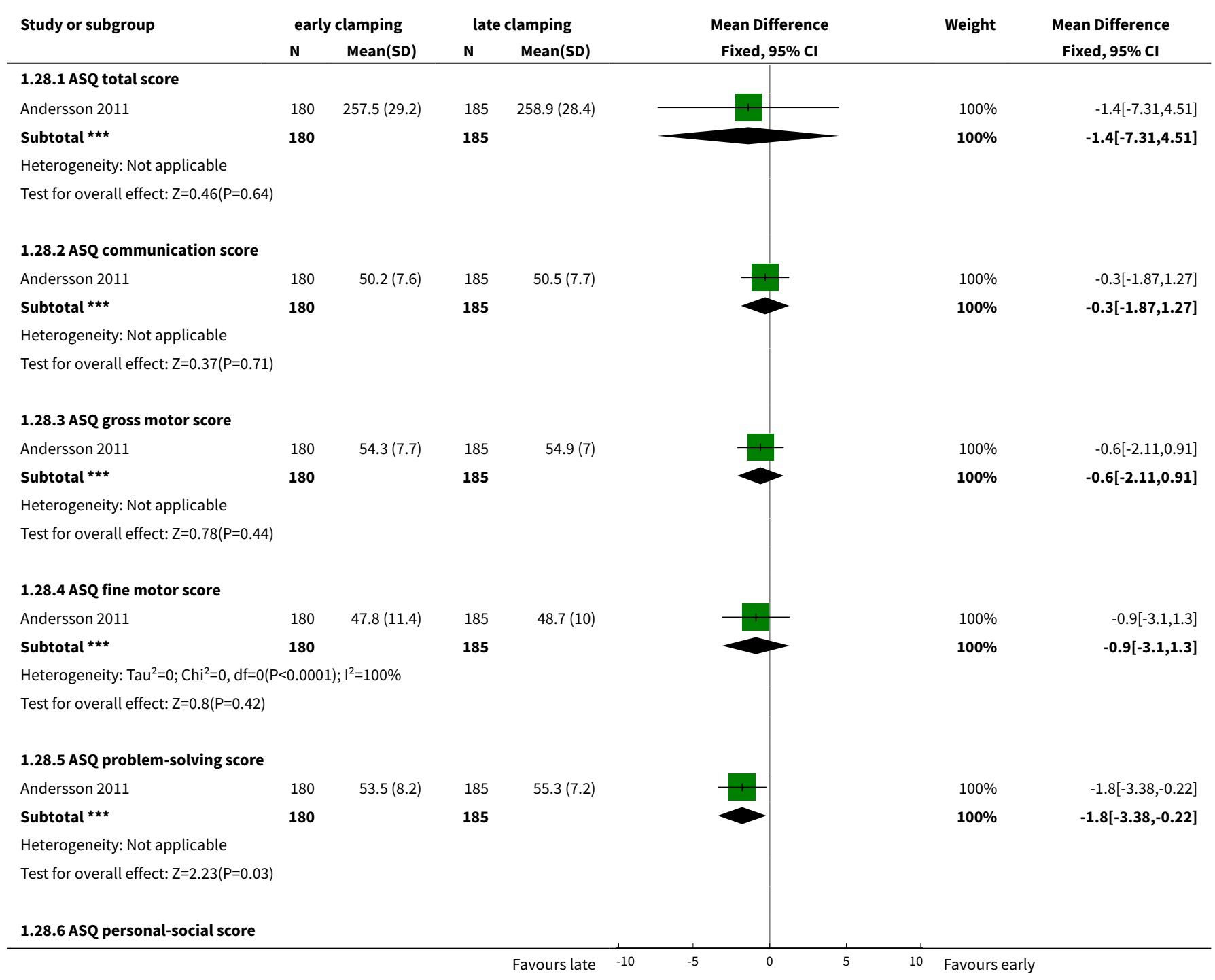




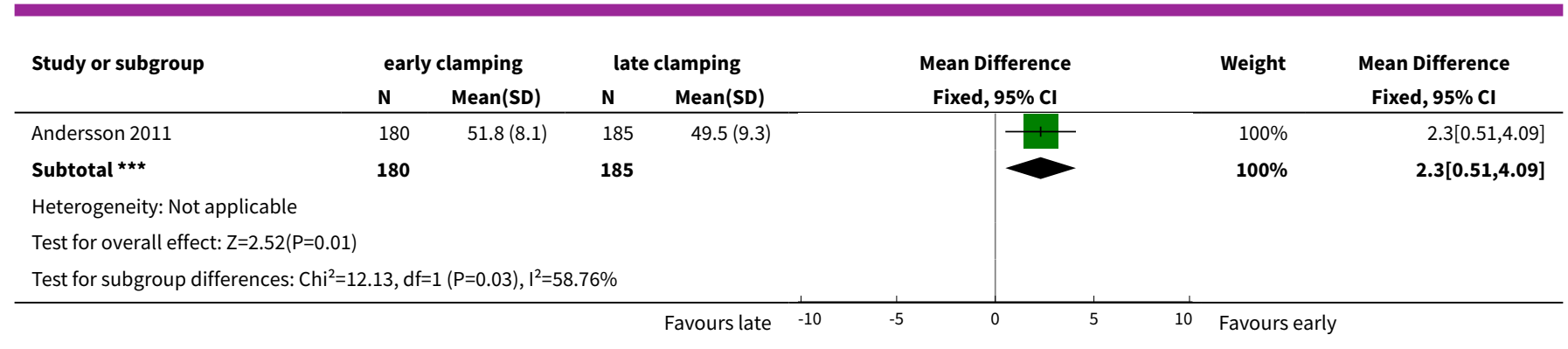

\section{Analysis 1.29. Comparison 1 Early versus late cord clamping,} Outcome 29 Symptoms of infection during first 4 months.

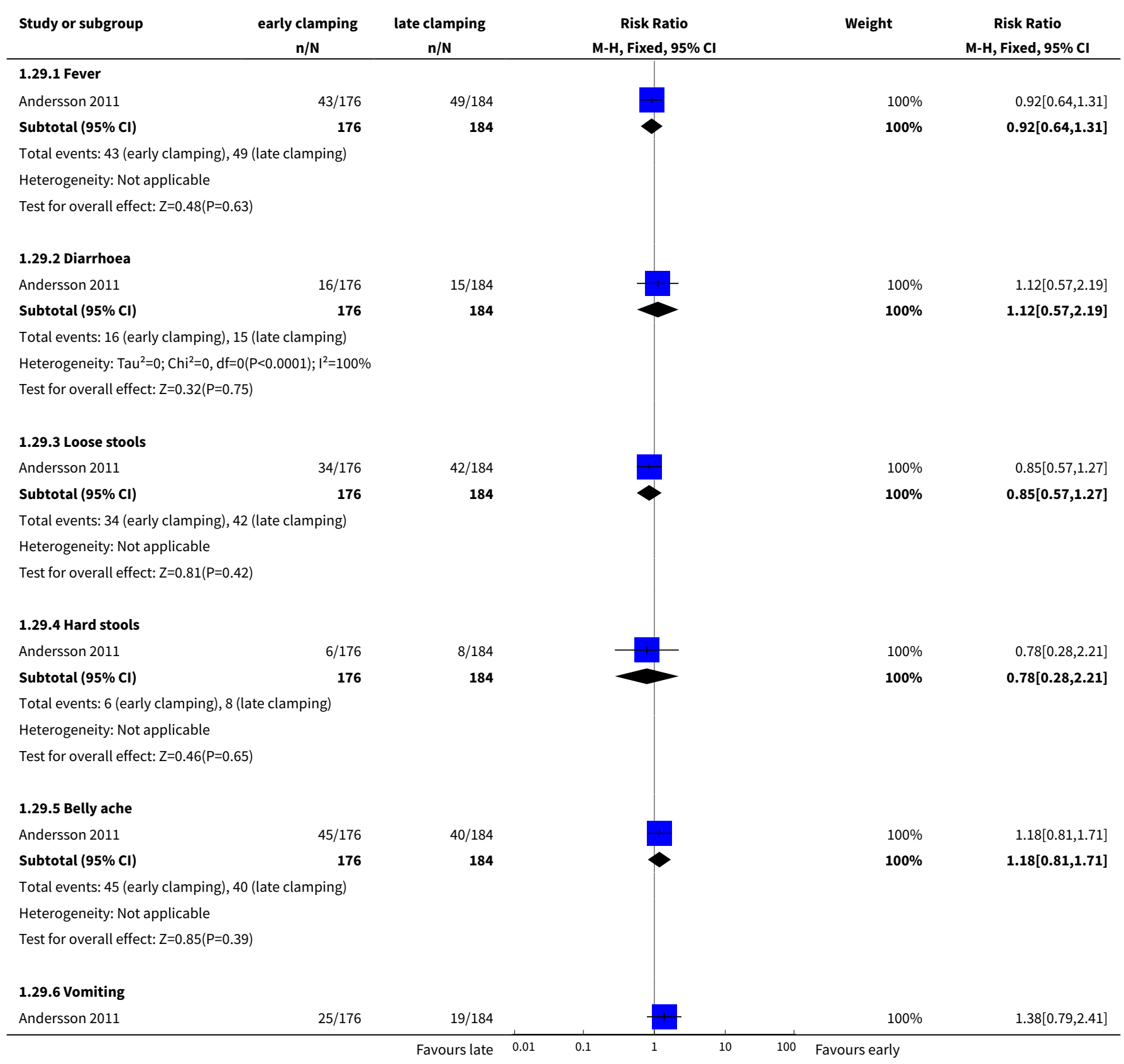




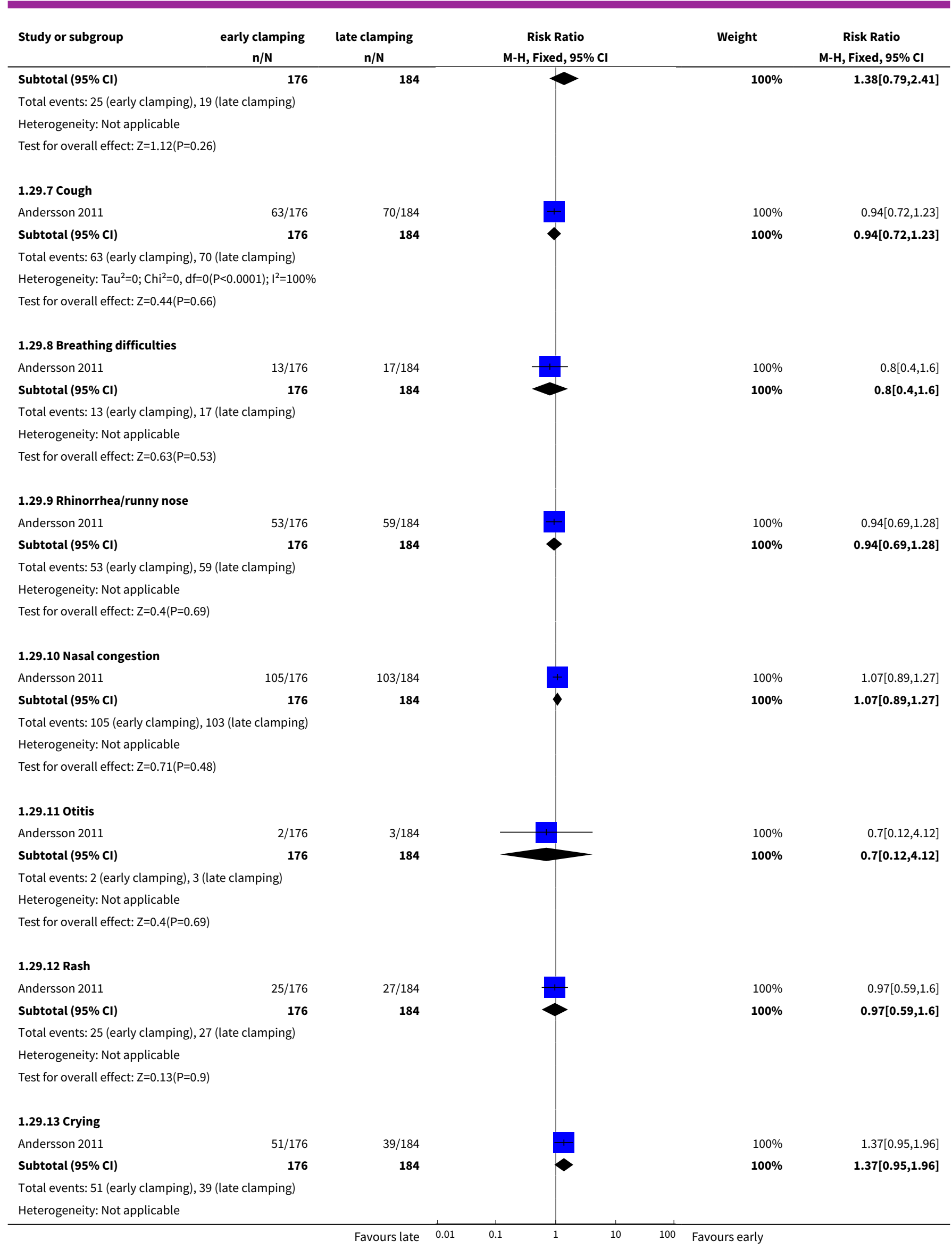

Effect of timing of umbilical cord clamping of term infants on maternal and neonatal outcomes (Review) 


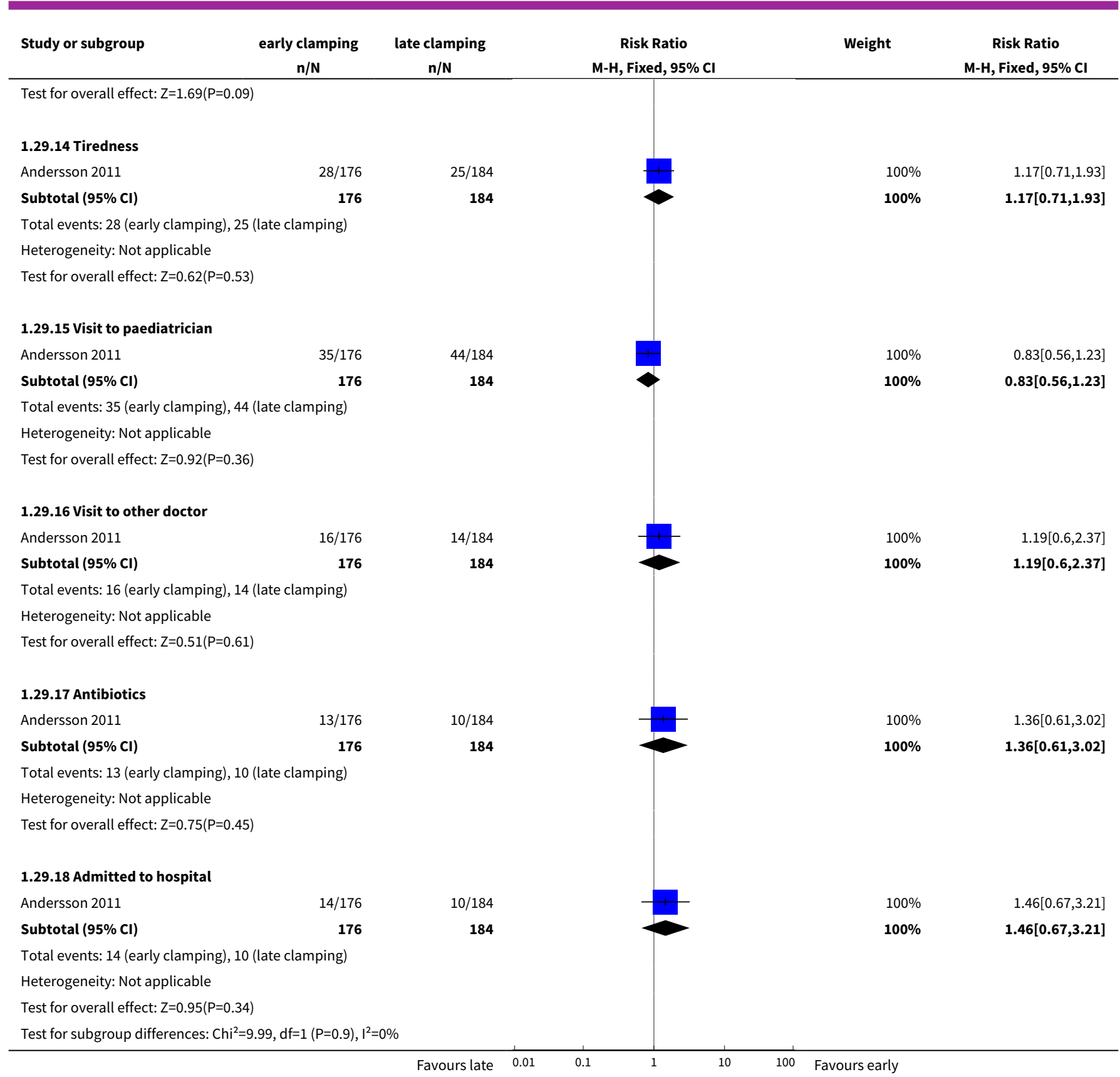

ADDITIONAL TABLES

Table 1. Infant iron deficiency and ferritin at 3-6 months

\begin{tabular}{lll}
\hline STUDY & Iron deficiency & Ferritin \\
\hline Al-Tawil 2012 & Data collected at 3-5 months & At 3-5 months. Defined as serum ferritin $<20$ \\
& Mean cell volume $<73 \mathrm{fL}$ & $\mathrm{Hg} / \mathrm{L}$ \\
& Early clamping group 4/78 & Early clamping group 12/78 \\
& Late clamping group 2/82 & Late clamping group 2/82 \\
\hline
\end{tabular}


Table 1. Infant iron deficiency and ferritin at 3-6 months

$P=0.43$

Transferrin saturation levels below 10\%

Early clamping group $11 / 78$

Late clamping group $8 / 82$

$P=0.62$
$\mathrm{P}<0.001$

Also reported mean (SD) ferritin

Early clamping group $(\mathrm{n}=78)$ mean $228(\mathrm{SD}$ 147)

Late clamping group $(n=82)$ mean 430 (SD

132) $\mathrm{P}<0.001$

Andersson $2011 \quad \begin{aligned} & \text { Defined as } 2 \text { or more indicators outside ref } \\ & \text { ranges (low ferritin, low mean cell volume, } \\ & \text { rin saturation, high transferrin receptors) }\end{aligned}$
At 4 months
Early clamping group 10/175
Late clamping group 1/172
$\mathrm{P}=0.01$
Also reported mean iron $(\mu \mathrm{mol} / \mathrm{L})$
At 4 months
Early clamping group $(\mathrm{n}=175) 9.3$ (SD 2.9)
Late clamping group $(\mathrm{n}=172) 10.2$ (SD 3.0)
P = 0.007

Cernadas 2006

Iron deficiency anaemia at 6 months (defined as $\mathrm{Hb}<$

Ferritin $<9 \mu \mathrm{g} / \mathrm{L}$ at 6 months $10.5 \mathrm{~g} / \mathrm{dL}$ and ferritin $<9 \mu \mathrm{g} / \mathrm{L})$

15 second group $6 / 86$

1-minute group $3 / 84$

15 second $13 / 86$

1 minute $10 / 83$

3-minute group 2/84

3 minutes $6 / 83$

Ferritin geometric mean at 6 months

15 seconds $(n=86) 20.9($ SD 26.3)

1 minute $(n=83) 25.5(S D 26.0)$

3 minute $(n=83) 33.2$ SD 36.8)

\begin{tabular}{|c|c|c|}
\hline \multirow[t]{2}{*}{ Chaparro 2006} & $\begin{array}{l}\text { Iron deficiency at 4-6 months (defined as ferritin }<9 \mu \mathrm{g} \text { / } \\
\text { L) }\end{array}$ & Ferritin $\mu \mathrm{g} / \mathrm{L}$ at 4-6 months. Mean and SD \\
\hline & $\begin{array}{l}\text { Early clamping } 12 / 154 \\
\text { Late clamping } 3 / 161 \\
P=0.02\end{array}$ & $\begin{array}{l}\text { Early clamping }(n=154) 34.9(32.2) \\
\text { Late clamping }(n=161) 46.7(37.7) \\
P=0.001\end{array}$ \\
\hline Geethanath 1997 & Not reported & $\begin{array}{l}\text { Ferritin } \mu \mathrm{g} / \mathrm{mL} \text { geometric mean at } 3 \text { months } \\
\text { (dispersion statistic not clear) } \\
\text { Earlvelamnino oroun }(n=48) 557(37)\end{array}$ \\
\hline
\end{tabular}


Table 1. Infant iron deficiency and ferritin at 3-6 months

Late clamping group $(n=59) 73.6(3.1)$

Difference not significant.

\begin{tabular}{|c|c|c|}
\hline \multirow[t]{4}{*}{ Gupta 2002} & Not reported & $\begin{array}{l}\text { Ferritin } \mu \mathrm{g} / \mathrm{L} \text { geometric mean, median and } \\
\text { range at } 3 \text { months. }\end{array}$ \\
\hline & & $\begin{array}{l}\text { Early clamping }(n=29) \text { geometric mean } 73.04 \text {, } \\
\text { median and range } 80(15 \text { to } 180)\end{array}$ \\
\hline & & $\begin{array}{l}\text { Late clamping }(n=29) \text { geometric mean } 118.39 \text {, } \\
\text { median and range } 105(30 \text { to } 500)\end{array}$ \\
\hline & & $P=0.02$ \\
\hline
\end{tabular}

van Rheenen 2007

Iron deficiency anaemia (defined as zinc-protopor-

phyrin (ZPP) $>80 \mu \mathrm{mol} / \mathrm{mol}$ haem and $\mathrm{Hb}<10.3$ )

At 4 months

Immediate clamping 14/39

Delayed clamping 6/39

NS

At 6 months

Immediate clamping 17/37

Delayed clamping 17/35

NS

Iron deficiency (ZPP > $80 \mu \mathrm{mol} / \mathrm{mol}$ haem)

At 4 months

Delayed clamping 27/39

Immediate clamping 28/39

NS

At 6 months

Delayed clamping 27/35

Immediate clamping 28/37

NS

fL: femtolitre

$\mathrm{Hb}$ : haemoglobin

SD: standard deviation 


\section{FEE D B A C K}

\section{Erickson-Owens and Mercer, 21 April 2008}

\section{Summary}

First we would like to thank Susan J McDonald and Philippa Middleton on completion of the huge task of reviewing all of the literature on delayed cord clamping in term infants. This is a daunting task and they are to be commended.

However, we do have two serious concerns that we feel significantly weaken this Cochrane review. Our first concern is that the evidence for an increase in 'jaundice requiring phototherapy' is based upon one 12 year old unpublished trial done by the lead author of this Cochrane Review (McDonald) in Australia. When that one trial is removed from data (offered in Analysis 1.14 ) the variable of 'jaundice requiring phototherapy' does not reach significance. A recent meta-analysis found in JAMA did not agree with the outcome that delayed cord clamping (DCC) leads to 'jaundice requiring phototherapy' (Hutton and Hassan, 2007). We question the emphasis given to the outcome drawn from this one study.

There are several reasons in this Cochrane Review why 'jaundice needing phototherapy' (associated with DCC) may be misleading. First, no information is offered to tell the reader if the providers ordering the phototherapy in the McDonald trial were blinded to the infants grouping. Secondly, guidelines to treat jaundice have changed over time and no mention is given of what the guidelines were in Australia 12 years ago. How high were the bilirubin levels? What was the age of the infants at the time that phototherapy was indicated? Did any of the infants require further treatment such as exchange transfusions? What were the feeding policies at the time and how many mothers were breastfeeding and bottle feeding? What was the racial mix and was metabolic screening to rule out G6PD, galactosemia and other conditions considered? These questions suggest competing factors and other potential influences rather than DCC only on the incidence of jaundice needing phototherapy in McDonald's 12 year old unpublished controlled trial.

Our second main concern is that harm to infants from DCC is inferred but not demonstrated in this review. The use of the word 'severe' in the Plain Language Summary is particularly misleading. Was there 'harm' to any of the infants in the McDonald study or simply more infants receiving phototherapy? What were peak bilirubin levels? The use of phototherapy does not necessarily imply 'severe' jaundice. Maisals (2006) recommends that the term severe be used when the total serum bilirubin level is $20 \mathrm{mg} / \mathrm{dL}$ ( $340 \mathrm{umol} / \mathrm{L}$ ) or higher. The issue of hyperbilirubinemia is extremely complex (AAP, Technical Report 7/04). Recent information on bilirubin tells us that it is an antioxidant and that the elevations seen after birth especially in breastfed infants may be initially protective (Hammerman C et al, 2002). It does everyone an injustice to infer 'harm' in the face of the evidence from the two large randomized controlled trials published in 2006. These trials indicate less anemia and better iron stores at 6 months of age in infants with DCC at birth (Cernadas et al, 2006; Chaparro et al, 2006).

In analysis 1.16 'Clinical Jaundice' did not result in significant differences between the delayed group and the immediate clamped group even though the 90 infants who were clamped at 3 minutes in the Cernadas study (2006) with no increase in jaundice are left out and the McDonald study results are included here as well.

It is important to blind pediatric providers when one is using a management decision as an outcome variable. Strauss (2008) recently published findings on 105 preterm neonates randomized to immediate clamping or a one minute delay in cord clamping. Use of phototherapy was an outcome variable and the providers caring for the infants were not blinded to the infants grouping. He reported that even though there were "no differences in serum bilirubin values prompting therapy or in intensity of therapy required", more infants with the delay in cord clamping group received phototherapy (Strauss, 2008). This information concerning treatment when neonatologists are unblinded to an infant's grouping suggests that the belief that DCC causes jaundice effects clinical practice. It demonstrates the need for pediatric providers to be blinded in trials using jaundice requiring phototherapy as an outcome variable. Fortunately, Strauss balanced his variables and reported that there were no differences in initial bilirubin levels at decision to treat or in the extent of phototherapy used.

In order to prevent regional biases, we suggest that the Cochrane Collaboration recommend groups of authors representing more than one country, one continent, and one specialty. This is imperative to offer balance for such an important review.

Other points are:

1. The abstract offers that both benefits and harm are shown for late cord clamping. The evidence of harm in this review is much too weak (based on one unpublished study's findings) to be stated so definitively.

2. Under 'Significant increase in infants needing jaundice', five trials are listed but only one trial gives any weight to this finding and that is a 12 year old unpublished study.

3. Under Authors' Comments, the authors state "One definition of active management [of third stage labor]" but do not refer to the current definition as offered by WHO, ICM, and FIGO. It is imperative that such documents use and refer to the most current definitions.

\section{References}

AAP Technical Report. An evidence-based review of important issues concerning neonatal hyperbilirubinemia. Pediatrics 2004, 114(1):e130-153. 
Cernadas, J., et al. (2006). The effect of timing of cord clamping on neonatal venous hematocrit values and clinical outcome at term: A randomized controlled trial. Obstetrical \& Gynecological Survey, 61(9):564-565.

Chaparro, C.M., et al. (2006). Effect of timing of umbilical cord clamping on iron status in Mexican infants: a randomised controlled trial. Lancet, 367 (9527):1997-2004.

Hammerman C, Goldschmidt, D, Caplan, M. S, Kaplan, M. Bromiker, R. Eidelman, A. I.et al. (2002) Protective Effect of Bilirubin in Ischemia? Reperfusion Injury in the Rat Intestine Journal of Pediatric Gastroenterology and Nutrition, 35:344?349.

Hutton, E.K. and Hassan, E.S. (2007). Late vs. early clamping of the umbilical cord in full-term neonates: systematic review and metaanalysis of controlled trials. JAMA, 297(11):1241-52.

Maisels, MJ. (2006). What?s in a Name? Physiologic and pathologic jaundice: the conundrum of defining normal bilirubin levels in the newborn. Pediatrics, 118(2):805-807.

Strauss, R.G. et al. (2008). A randomized clinical trial comparing immediate versus delayed clamping of the umbilical cord in preterm infants: short-term clinical and laboratory endpoints. Transfusion, 48(4):658-65.

(Feedback received from Judith S Mercer, PhD, CNM, FACNM and Debra A Erickson-Owens, PhD(c), CNM)

\section{Reply}

\section{Jaundice requiring phototherapy}

\section{Emphasis}

Debra Erickson-Owens and Judith Mercer question the emphasis we have placed in the review on this outcome. We believe that our presentation of jaundice requiring phototherapy accurately reflects an increase in jaundice. The authors recognise that interpretation of the clinical relevance of this for infants may vary. As the largest trial, the McDonald study (appropriately) contributes the most data, so it is not surprising that its removal from the analysis also removes the statistical significance. Three of the other four trials contributing data to this outcome are small. The fourth trial of 556 babies (Oxford Midwives 1991) shows a risk difference of approximately similar magnitude to McDonald 1996 (2.5\% versus 3.1\%).

\section{Blinding}

In the McDonald 1996 trial, while it is possible that lack of blinding may have had an influence, we think that it is unlikely since women were not explicitly informed of their allocation at the time of birth. In the period that most of these trials were conducted, in many units, the midwives at the birth would not be the midwives providing postnatal care. In the McDonald study, midwives and other clinicians providing postnatal care were not aware of allocations to groups, or even that a particular infant had participated in the study. Furthermore, the decision to place a baby under phototherapy has many objective elements and criteria. We did include a brief mention of blinding of outcome assessment in the text of the review, but have added extra detail in the Characteristics of Included studies.

\section{Guidelines for treating jaundice}

We agree with the statement that these guidelines have changed over time. In the case of the McDonald 1996 trial, the level of jaundice requiring phototherapy depended on the age and weight of the infants (all were under four days). Approximately $90 \%$ of babies were breastfed at discharge ( $89 \%$ in the delayed clamping group and $91 \%$ in the early clamping group).

\section{Other factors}

The other factors mentioned would have been distributed between the two groups of the McDonald 1996 study, as it was a securely randomised trial with adequate allocation concealment.

\section{Ignoring results from Cernadas}

All infants from the Cernadas study (including the 90 infants clamped at three minutes) have been included in the clinical jaundice outcome. We feel that we have given appropriate weight to the favourable results for six-month anaemia and iron levels, pointing this out in the Results, Discussion, Authors' conclusions and Abstract.

\section{Potential risks from delayed cord clamping}

We think there is a slight misinterpretation about the Plain language Summary saying that the jaundice was severe - our actual words were "a possible additional risk of jaundice severe enough to require phototherapy". However, we can see that this wording could be easily misinterpreted and we will change it and also the applicable wording in the Authors' conclusions.

We feel it would be irresponsible to ignore or downplay potential harms and, in fact, to do so would be contrary to The Cochrane Collaboration's guidelines (Loke 2008). We believe we have appropriately pointed out a potential risk (albeit one which is preventable through phototherapy), noting that this risk would be minimal in facilities that have the equipment to test for and treat jaundice. Although Moerschel 2008 have recently stated, "every hospital that cares for newborns should be able to provide intensive phototherapy", we recognise that this is not always the case. 


\section{Clinical jaundice}

Thank you for picking up that we missed reporting the third arm of Cernadas for clinical jaundice. The addition of these data change the total RR from $0.83,95 \% \mathrm{Cl} 0.65$ to 1.06 to $0.84,95 \% \mathrm{Cl} 0.66$ to 1.07 . We have made this change in the review.

\section{Current definitions of active management}

The point of our comment in the conclusions in the Abstract was to highlight that active management takes a number of forms, as evidenced by the Winter 2007 survey that we cite in the background. Part of this variation will always exist, as conditions at birth sometimes mean that components of intended active management or expectant management cannot be carried out. We will refer to the current definitions in the review and add the appropriate reference when we update the review.

\section{Contributors}

Feedback received from Judith S Mercer, PhD, CNM, FACNM and Debra A Erickson-Owens, PhD(c), CNM

Reply from Susan J McDonald and Philippa Middleton

\section{Simon, 26 May 2008}

\section{Summary}

'Delayed clamping' of the umbilical cord at birth appears to be regarded as a novel alternative to a longstanding protocol for immediate disconnection of an infant from placental circulation within seconds of birth.

How many prospective parents are aware of the protocol for clamping the umbilical cord immediately at birth? How many prospective parents are fully informed about randomized controlled trials before assenting to random assignment to one group or another?

The infant does not gain 30 per cent more blood volume when the cord is left intact until pulsations cease. On the contrary the infant loses 30 per cent of its blood volume if placental circulation is clamped off immediately at birth.

The placenta is the respiratory organ of the child until its blood is transferred to the capillaries surrounding the alveoli and the lungs become fully functional. Pulsations in the cord are from the infant's heart continuing to make use of fetal circulation back to the placenta until the foramen ovale, ductus arteriosus, and pulmonary bypass circulation have closed. Clamping a pulsating umbilical cord arbitrarily terminates postnatal placental circulation. Redistribution of blood to the lungs, the brain, the gut will be variable from infant to infant.

Randomized controlled trials show that most healthy newborn babies somehow adjust, but findings like increased bilirubin levels are insufficient justification for promoting continued use of the obstetric clamp.

Oxygen insufficiency is the greatest danger of disrupted umbilical blood-flow, prenatally, during labor, when the cord is wrapped around the neck, and after birth. Bilirubin is only a danger if the blood-brain-barrier is disrupted, as demonstrated by research like that of Lucey et al (1964) and Lou et al (1977). Why is evidence of this kind, obtained in experiments with animals overlooked in favor of randomized controlled experiments with human children?

References (with notes from my recent comment to the Interagency Autism Coordinating Committee, IACC)

1. Lucey JF, Hibbard E, Behrman RE, Esquival FO, Windle WF. Kernicterus in asphyxiated newborn monkeys. Exp Neurol 1964 Jan; 9(1):43-58. Lucey et al induced hyperbiliruninemia in fourteen newborn monkeys by injecting a solution of bilirubin into the bloodstream every six hours. Bilirubin levels of 20 to $35 \mathrm{mg}$ were maintained for up to 96 hours. Then, "Six healthy full-term monkeys were asphyxiated at birth. A rubber bag filled with saline solution was placed over the fetal head as it was delivered from the uterus before the first breath. The umbilical cord was then clamped and asphyxiation carried out for 10 or 12 minutes" [p45]. Hyperbilirubinemia was then induced in the asphyxiated monkeys as in the fourteen control animals.

Lucey et al described the monkeys made hyperbilirubinemic as showing marked yellow coloration of skin and mucous membranes. Those not asphyxiated became slightly lethargic but none developed signs of neurological impairment. Monkeys subjected to asphyxia before induction of hyperbilirubinemia developed tremors, seizures, and prolonged periods of opisthotonus (a postural state with arched back and neck).

"Hyperbilirubinemia alone did not result in selective staining of nuclei in the brain, such as is associated with human kernicterus - the brains had a diffuse, faint to moderate, yellow color, but no extravascular bilirubin was seen" [p50].

Bilirubin is not directly toxic to the brain. Asphyxia appears to break down the blood-brain barrier, which then allows bilirubin to get into neural cells. As Zimmerman and Yannet noted in 1933, 'any intravital dye will localize in zones of injury and will leave unstained tissues which are not damaged.' [4, p757]

2. Lou HC, Tweed WA, Johnson G, Jones M, Lassen NA. Breakdown of blood/brain barrier in kernicterus. Lancet. 1977 May 14;1(8020):1062-3. Lou et al (1977) addressed what appeared to be the primary concern over "delayed" cord clamping allowing placental transfusion [5]. Citing the paper by Lucey et al (1964) they stated: 
"Asphyxiated infants are especially susceptible to kernicterus, even if their plasma-bilirubin levels are low. Furthermore, it is very difficult to produce clinical and pathological signs of kernicterus by injection of bilirubin intravenously in normal infant monkeys, while kernicterus was readily produced in previously asphyxiated monkeys." [p1062] Mossakowski et al (1968) used Evans blue dye to investigate the bloodbrain barrier in newborn monkeys subjected to asphyxia by clamping the umbilical cord and obstructing the airway [6]. Lou et al also used Evans blue dye in fetal lambs subjected to oxygen insufficiency for 1-2 hours:

"The fetuses were asphyxiated by partially inflating a cuff around the umbilical cord.

Asphyxia developed over a period of 1-2 $\mathrm{h}$ ( $\mathrm{pH}$ about 690)." [p1062] The initial response of the fetal lambs was a slowing of heart rate and increased blood pressure during the first half- to one-hour period of umbilical cord blood flow restriction. After that the blood pressure declined and remained low. Twinning is frequent in lambs, and Lou et al used the twin as a control for the fate of Evans blue dye, and reported:

"We have found, in experimental asphyxia lasting 1-2 h, a striking discoloration throughout cortex and basal ganglia after intravenous injection of $3 \mathrm{ml} / \mathrm{kg}$ of a $2 \%$ solution of Evans blue in eight non-exteriorised fetal lambs, in contrast to the uncoloured brain tissue in nonasphyxiated twins acting as controls." [p1062] In conclusion they commented:

"We suggest that the breakdown of the fetal blood/brain barrier to albumin is due to a combination of the initial moderate hypertension and severe vasodilation during asphyxia. The permeability of the blood/brain barrier to albumin in asphyxiated babies would facilitate the transport of bilirubin from plasma to neurones and thus explain the increased susceptibility to kernicterus." [p1063] If a baby does not breathe right away at birth, should the umbilical cord be clamped off right away? Respiratory depression in infants born alive is a current concern and topic for research [7,8]. If an infant is born alive, it has been receiving oxygen through the umbilical cord up to the time of birth. Shouldn't that lifeline be left intact until the lungs become functional?

Breakdown of the blood brain barrier by asphyxia has been shown to allow bilirubin and other substances in the circulation to enter the brain. High levels of bilirubin won't affect the brain if the blood-brain barrier has not been breached. Immediate clamping has been too long defended as a means to avoid circulatory overload and hyperbilirubinemia.

Lou et al (1979) reported results of more research on the vulnerability of the blood-brain barrier to circulatory insufficiency in fetal lambs [3].

3. Lou HC, Lassen NA, Tweed WA, Johnson G, Jones M, Palahniuk RJ. Pressure passive cerebral blood flow and breakdown of the bloodbrain barrier in experimental fetal asphyxia. Acta Paediatr Scand. 1979 Jan;68(1):57-63.

4. Zimmerman HM, Yannet H. Kernicterus: jaundice of the nuclear masses of the brain. American Journal of Diseases of Children $1933 \mathrm{Apr}$; 45:740-759.

Before discovery of Rh factor sensitivity, Zimmerman and Yannet in 1933 summarized a large number of case reports of kernicterus. They concluded that kernicterus was caused by bilirubin staining of subcortical nuclei already injured by sepsis or oxygen deprivation. They further commented, "This differs in no way from the well known fact that any intravital dye will localize in zones of injury and will leave unstained tissues which are not damaged," [p757].

Fear of elevated bilirubin levels became a prime reason 40 years later for advocating immediate clamping of the umbilical cord at birth to minimize placental transfusion [4].

5. Saigal S, O'Neill A, Surainder Y, Chua LB, Usher R. Placental transfusion and hyperbilirubinemia in the premature. Pediatrics. 1972 Mar;49(3):406-19.

Is it safe to allow a placental transfusion? By the 1970s the practice of clamping the cord was so widespread, at least in obstetric practice associated with academic institutions, that whether a placental transfusion should be allowed became a major topic for research. Thus the opening comment of this highly influential report states:

"In full-term infants placental transfusion increases the blood volume of the newborn by $40 \%$ to $60 \%$ within 5 minutes of birth. Most of the excess blood volume is eliminated within 4 hours by an extravasation of plasma from the circulation. For the remainder of the neonatal period, such infants retain a 50\% larger red cell volume dispersed through a slightly enlarged blood volume, with higher hematocrit values than are found in infants whose umbilical cords are clamped immediately at birth." [p406] "If delayed cord clamping is adopted as a means to reduce the incidence of respiratory distress syndrome in premature births, there will be accompanying augmentation of hyperbilirubinemia to deal with." [p418] This paper, with its single focus on bilirubin danger, has been one of the most influential in adopting immediate clamping of the umbilical cord at birth as a standard protocol.

6. Mossakowski MJ, Long DM, Myers RE, DeCuret HR, Klatzo I. The early histochemical and ultrastructural changes in perinatal asphyxia. J Neuropathol Exp Neurol. 1968 Jul;27(3):500-516.

7. Baskett TF, Allen VM, O'Connell CM, Allen AC. Predictors of respiratory depression at birth in the term infant. BJOG. 2006 Jul;113(7):769-74.

8. Milsom I, Ladfors L, Thiringer K, Niklasson A, Odeback A, Thornberg E. Influence of maternal, obstetric and fetal risk factors on the prevalence of birth asphyxia at term in a Swedish urban population. Acta Obstet Gynecol Scand. 2002 Oct;81(10):909-17.

(Feedback from Eileen Nicole Simon, PhD, RN) 


\section{Reply}

Many of the comments in Simon's feedback are outside the scope of this Cochrane review. However, responses to some specific issues follow:

\section{Delayed clamping regarded as novel}

Cochrane reviews are often done when there is variation in practice, as is the case here. For example, in the Background of the review we cite such documented variation which indicates widespread use of both delayed and immediate cord clamping, and we make no judgement about the novelty or otherwise of either technique.

\section{Infant loses $\mathbf{3 0} \%$ of blood volume, does not gain $30 \%$}

Our phrasing in the background is about transfer of fetal blood. In order to clarify further, we have added "compared with immediate cord clamping" after "This placental transfusion can provide the infant with an additional $30 \%$ more blood volume and up to $60 \%$ more red blood cells".

\section{Increased bilirubin levels are insufficient justification for promoting continued use of the obstetric clamp}

Firstly our review does not promote the continued use of clamping; in fact, it is more the reverse. However, we do note that increased levels of jaundice may be associated with delayed cord clamping, which is the responsible course of action.

\section{Evidence from animal studies should suffice}

This is not the place for a detailed discussion of the pros and cons of using data from animal studies, except to say that most clinicians and researchers would be very cautious about extrapolating to humans, especially human infants.

\section{Saigal 1972 influenced adopting immediate cord clamping as a standard protocol}

This may well be so, but the Saigal study did not contribute data to the outcome of jaundice in this review (as they reported only the biochemical outcome of bilirubin levels and not jaundice). The fundamental purpose of systematic reviews is to show the consolidated evidence of benefits and harms of particular actions, not to rely on single studies or opinion.

\section{Contributors}

Feedback from Eileen Nicole Simon, PhD, RN

Reply from Susan J McDonald and Philippa Middleton

\section{Buckley, 16 July 2008}

\section{Summary}

I am very concerned about one of the studies used for this conclusion: Following birth, there was a significant increase in infants needing phototherapy for jaundice (RR $0.59,95 \% \mathrm{Cl} 0.38$ to 0.92 ; five trials of 1762 infants) in the late compared with early clamping group.

This finding (analysis 1.15) is significantly influenced by results from the Oxford Midwives study (Oxford Midwives 1991), which is quoted here as showing jaundice requiring phototherapy amongst 3/256 immediate cord-clamped (ICC) babies and 11/296 delayed cord clamped (DCC) babies.

However, a close reading of this paper shows a significant disparity in these groups in relation to exposure to synthetic oxytocin in labour: $33 / 256(12.9 \%)$ in ICC group and 72/296 (24.3\%) in the DCC group: see table 1.

Study authors note this (and the association between exposure to synthetic oxytocin in labour and jaundice), and, in table 6 of this paper, reanalyze the groups in relation to oxytocin exposure, finding 5/70 DCC versus $2 / 33$ ICC babies exposed to oxytocin required phototherapy for jaundice, and $6 / 222$ DCC versus $1 / 218$ ICC unexposed to oxytocin. In this analysis, the confidence intervals were wide and the differences between ICC and DCC babies were not significant in either group.

I am concerned that the reviewers have not adjusted for this confounding factor, which is very salient to the findings and to the overall review conclusions, and would welcome a reanalysis of table 1.15 .

There were some other worrying elements in this study:

- Lack of blinding to allocation, leaving the possibility that clinicians may have referred more jaundiced DCC babies for phototherapy because of their own beliefs.

- A sizeable unexplained disparity in numbers randomized to each arm: 296 DCC versus 256 ICC.

- A large number of protocol deviations in the DCC arm (32 versus 3 ICC). 
I also note the small numbers of events used in analysis 1.15 .

I (and many others interested in this area) would also welcome access to detail from the unpublished study (McDonald 96) that seems to have influenced this finding.

(Feedback received from Dr Sarah J Buckley)

\section{Reply}

The actual influence of infants exposed to synthetic oxytocins in the Oxford Midwives study is minimal; a re-analysis omitting these infants changes the overall risk ratio (of the pooled studies) from $0.5995 \% \mathrm{Cl}$ to 0.38 to 0.92 ; to $0.5995 \% \mathrm{Cl} 0.37$ to 0.95 .

While it is possible that lack of blinding may have had an influence, we think that it is unlikely, since women were not explicitly informed of their allocation at the time of the birth. In the period that most of these trials were conducted, midwives present at the birth would not be the midwives providing postnatal care. In the McDonald Study, postnatal ward staff were not aware of allocations to groups, or even that a particular infant had participated in the study. Furthermore, the decision to place a baby under phototherapy has many objective elements and criteria.

We agree that the study authors did not explain the reasonably large discrepancy in numbers randomised to delayed and immediate cord clamping (296 versus 256) but do not have the information to assess any impact of this on the trial's reported results.

Some protocol deviations are to be expected with the nature of these interventions; particularly for delayed cord clamping where immediate cord clamping may have to be carried out in some cases. The study authors analysed these deviations correctly (in the groups to which the mothers were originally randomised). However, an additional 'as treated' analysis would have been informative.

Small numbers of events usually are associated with less precision, so it is interesting to see that the pooled result reached statistical significance with these small numbers.

The McDonald trial is a thesis, available from the Cochrane Pregnancy and Childbirth Group or from Professor McDonald. A journal manuscript is being prepared.

\section{Contributors}

Feedback from Dr Sarah J Buckley

Reply from Susan J McDonald and Philippa Middleton

\section{Oddie, 7 July 2008}

\section{Summary}

Why is the weight of the infants not reported in the review? These data will be available to the reviewers and will answer some of the questions as to how large the placental transfusion actually is in reality.

Where this practice has not yet been adopted, or further studies are planned, these data are very relevant.

(Feedback from Sam Oddie)

\section{Reply}

Thank you for pointing out this omission. Approximately half of the studies did report birthweight. We will add birthweight to the next revision of the review. A preliminary assessment of the available data reveals no statistically significant difference between the late and early cord clamping arms

\section{Contributors}

Feedback from Sam Oddie

\section{Oddie, 7 July 2008}

\section{Summary}

Feedback: I am really interested in the data and have reviewed some of the original trials, as well as taking an active ongoing interest in the issue.

I remain unconvinced that DCC ought to be adopted widely in iron replete areas.

But my feedback is: Why is infant weight not reported? 
Justification: If the size of the transfusion is anywhere near as big as many suggest, then it must be the case that a difference in weight can be shown as so many women have been randomised. If no such weight effect is shown, then either the transfusion is smaller than is suggested, randomisation is in some way ineffective, or there is still inadequate power for these RCTs to show us the size of the transfusion. It seems unlikely that the latter is true.

Many who write on this subject are increasingly keen on DCC. This is obviously fine, but for those of us who are not yet practising it, or who are planning further work, the actual size of the transfusion is relevant; particularly when there is a suite of trials and a way to answer the question. I do know of some who are suspicious as to why the weight data are as yet unpublished.

As birthweight will undoubtedly have been recorded in the trials, lets report it here!

(Feedback from Sam Oddie)

\section{Reply}

The question of the amount of transfusion cannot be answered in a satisfactory amount of detail through the randomised trials we have included in this review. This would require another prospective study of comparing birthweights with timing of clamping.

\section{Contributors}

Feedback from Sam Oddie

Reply from Susan J McDonald and Philippa Middleton

Hutchon, 18 May 2015

\section{Summary}

My concern about this review is the conclusion that "Delayed cord clamping is likely to be beneficial as long as access to treatment for jaundice requiring phototherapy is available." This conclusion came from the finding that "Fewer infants in the early cord clamping group required phototherapy for jaundice than in the late cord clamping group ( $R R$ 0.62, 95\% Cl 0.41 to 0.96, data from seven trials, 2324 infants with a LCER of $4.36 \%, 120 \%)$."

Data on phototherapy for jaundice comes largely from McDonald 1996, the full report of which is unpublished. Some parts of this trial are published, but the full report is available only through the Pregnancy and Childbirth Group Editorial Office in Liverpool. It is notable that an earlier systematic review[1], which did not include McDonald 1996, did not find any clear increase in the need for phototherapy. The conclusion of the current Cochrane review is extremely important because many units are still carrying out routine early cord clamping because of the fear of not having sufficient resources for phototherapy.

The increased need for phototherapy for non-haemolytic hyperbilirubinaemia is frequently given as a barrier to the introduction of delayed cord clamping. However the evidence for this increased need is not consistent. At one end of the scale there is one subgroup of McDonald 1996 combined with Oxford Midwives 1991 reporting a relative risk (RR) of needing phototherapy to be $0.59(95 \% \mathrm{Cl} 0.32$ to 1.11$)$ for early clamping compared with delayed clamping, and the second subgroup of McDonald 1996 study reporting a RR of 0.47 (0.22 to 0.97 ). On the other hand Andersson 2011 and Emhamed 2004 had very few babies needing phototherapy, and the trend was in the opposite direction to that in McDonald 1996 and Oxford Midwives 1991, with slightly more babies receiving phototherapy after early cord clamping. There was no clear difference in the mean bilirubin level between the two groups. The two other studies Nelson 1980 and van Rheenen 2007 also had small numbers of babies receiving phototherapy. The two studies which strongly influence the conclusion that late cord clamping is associated with an increased need for phototherapy were both carried out in the 1990's. As has been pointed out ${ }^{2}$, there was no consistent threshold of bilirubin for deciding when to use phototherapy and the clinicians were not blinded, so bias was possible. Has the use of phototherapy been modified since the 1990's, and does this explain the marked difference? In the three studies carried out before 2000 the use of phototherapy was $6 \%$ while in the three studies after 2000 it was only $0.9 \%$. McDonald 1996 reported the greatest number of babies receiving phototherapy, and this has the greatest influence on the conclusion of this review. Although there was no statistically significant difference between groups for the diagnosis of clinical jaundice, there was a difference for receiving phototherapy. This may have been because of bias in deciding phototherapy was needed, or at lack of consistency in the bilirubin threshold for intervention.

Intention-to-treat analysis (ITT) is used in the Cochrane Reviews. This is important as it reduces bias if participants do not receive the allocated intervention and or if there is loss to follow-up. For cord clamping trials the protocol should be designed so that maximal adherence is assured, as a large number of protocol violations related to compliance with the allocated intervention may invalidate the results. The perceived need for neonatal resuscitation is clearly a reason why babies allocated to delayed cord clamping may have early cord clamping. McDonald 1996 did not specifically exclude babies requiring resuscitation, although this was clearly going to result in noncompliance. In the unpublished full report (table 6.1) the largest number of participants who did not have the intervention as allocated was in the late cord clamping group, when the babies needed active resuscitation. 38 babies in the late cord clamping group did not have the allocated intervention compared with only one in the early cord clamping group. In Andersson 2011 there were $12.5 \%$ protocol violations equally distributed between early and late cord clamping. For this trial, analyses for the main and secondary outcomes, including cases of protocol breach at inclusion as well as per protocol $(n=334)$, did not alter the overall result. In the report of their trial these authors noted 
there have been "inconsistent results on the possible association between delayed cord clamping and neonatal jaundice, and the Cochrane review that reported a significant increase in infants needing phototherapy for jaundice relied heavily on unpublished data."

In McDonald 199638 women were allocated delayed cord clamping, but received early cord clamping. As the study had a factorial design these women were either allocated early oxytocic and late cord clamping, or late oxytocic and late cord clamping. It is possible that the non-compliance was in the timing of the oxytocic but this seems unlikely since early rather than delayed cord clamping is generally agreed as an indication for resuscitation. Although a tight nuchal cord is mentioned as a cause for non-compliance with delayed cord clamping it is not specifically listed in table 6.1. A tight nuchal cord managed by clamping and cutting is a significant risk for hypoxia and ischaemia. Feedback on this review comments " "In particular difficulty was experienced in the trial arms where late cord clamping was intended but only occurred in $50 \%$ of cases within the allocated time frame. The reasons listed mainly related to umbilical cord being tightly wound around the baby's neck, presence of meconium liquor or requirement for some form of active resuscitation that necessitated premature cord clamping." Thus 122 of 244 women allocated to delayed cord clamping actually received delayed clamping. 38 babies born to women allocated to delayed cord clamping had a need for resuscitation and therefore had early cord clamping.

Analysis by intention to treat becomes meaningless when there is a $50 \%$ protocol violation. So analysis by actual allocation can be considered. However it would be more appropriate to remove the study from the Cochrane Review.

It should also be noted that the primary focus of McDonald 1996 was the effect of timing of cord clamping on maternal postpartum haemorrhage. The need for phototherapy was not prespecified as a primary or secondary outcome, so it was not appropriate to use this in the systematic review.

\section{References}

1. Hutton EK, Hassan ES. Late vs early clamping of the umbilical cord in full-term neonates: systematic review and meta-analysis of controlled trials. JAMA 2007, 297:1241-1252.

2. McDonald SJ, Middleton P, Dowswell T, Morris PS. Effect of timing of umbilical cord clamping of term infants on maternal and neonatal outcomes. Cochrane Database of Systematic Reviews 2013, Issue 7. Art. No.: CD004074. DOI: 10.1002/14651858.CD004074.pub3. Feedback section, Comment by Mercer and Erickson-Owens 2008.

Comment received from David Hutchon, May 2015

\section{WHAT'S NEW}

\begin{tabular}{lll}
\hline Date & Event & Description \\
\hline 9 December 2015 & Feedback has been incorporated & Feedback 6 from David Hutchon added. \\
\hline
\end{tabular}

\section{H I S T OR Y}

Protocol first published: Issue 1, 2003

Review first published: Issue 2, 2008

\begin{tabular}{lll}
\hline Date & Event & Description \\
\hline 14 March 2013 & $\begin{array}{l}\text { New citation required and conclusions } \\
\text { have changed }\end{array}$ & $\begin{array}{l}\text { There is increased evidence that infant iron stores are improved } \\
\text { with late cord clamping. }\end{array}$ \\
\hline 13 February 2013 & New search has been performed & $\begin{array}{l}\text { The review has been updated. A new search was carried out in } \\
\text { February 2013. In this version of the review we have included } \\
\text { four new trials making a total of 15 included and 37 excluded tri- } \\
\text { als. }\end{array}$ \\
\hline 27 May 2008 & Feedback has been incorporated & $\begin{array}{l}\text { We have replied to feedback from DA Erickson-Owens and JS } \\
\text { Mercer, Eileen Simon, SJ Buckley and S Oddie. }\end{array}$ \\
\hline
\end{tabular}




\begin{tabular}{lll}
\hline Date & Event & Description \\
\hline 4 May 2008 & Feedback has been incorporated & $\begin{array}{l}\text { Added feedback from Erickson-Owens and Mercer and feedback } \\
\text { from Eileen Nicole Simon. }\end{array}$ \\
\hline
\end{tabular}

\section{CONTRIBUTIONS OFAUTHORS}

Sue McDonald, Philippa Middleton and Therese Dowswell wrote the review, carried out data extraction, set up the analysis and edited drafts. Peter Morris provided feedback and paediatric expertise to the review.

\section{DECLARATIONS OF INTEREST}

The contact review author (S McDonald) is the author of one of the included studies. The other review authors assessed this trial for potential inclusion and data extraction.

\section{SOURCES OF SUPPORT}

\section{Internal sources}

- Discipline of Obstetrics and Gynaecology, The University of Adelaide, Australia.

\section{External sources}

- Department of Health and Ageing, Australia.

- NIHR, UK.

TD is supported by the NIHR NHS Cochrane Collaboration Programme grant scheme award for NHS-prioritised centrally-managed, pregnancy and childbirth systematic reviews: CPGS 10/4001/02.

- National Health and Medical Research Council (NHMRC), Australia.

\section{DIFFERENCES BETWEEN PROTOCOL AND REVIEW}

Since the publication of the protocol for this review, we have broadened the criteria to include caesarean births and to widen the definition of early cord clamping from less than 30 seconds to less than 60 seconds since two trials specified early clamping as under one minute. We have added several outcomes that measure biochemical parameters in infants such as haemoglobin and ferritin. We added the outcome of polycythaemia because we considered that information regarding polycythaemia would be of clinical interest.

In 2013 the review includes restructured primary and secondary outcome criteria and we have now included birthweight and symptoms of infection in infants as secondary outcomes.

\section{N DEX TERMS}

\section{Medical Subject Headings (MeSH)}

*Umbilical Cord; Constriction; Iron [blood]; Jaundice, Neonatal [*etiology] [therapy]; Labor Stage, Third; Phototherapy; Placental Circulation [physiology]; Postpartum Hemorrhage [ ${ }^{*}$ prevention \& control]; Randomized Controlled Trials as Topic; Time Factors

\section{MeSH check words}

Female; Humans; Infant, Newborn; Pregnancy 